Supporting Information

\title{
Acyl Fluorides from Carboxylic Acids, Aldehydes, or Alcohols under Oxidative Fluorination
}

Yumeng Liang, ${ }^{1}$ Zhengyu Zhao, ${ }^{1}$ Akihito Taya ${ }^{1}$ and Norio Shibata*,1,2

${ }^{1}$ Department of Nanopharmaceutical Sciences \& Department of Life Science and Applied Chemistry, Nagoya Institute of Technology, Gokiso, Showa-ku, Nagoya, 466-8555, Japan.

${ }^{2}$ Institute of Advanced Fluorine-Containing Materials, Zhejiang Normal University, 688 Yingbin Avenue, 321004 Jinhua, China.

Correspondence and requests for materials should be addressed to N.S. (e-mail: nozshiba@nitech.ac.jp.) 


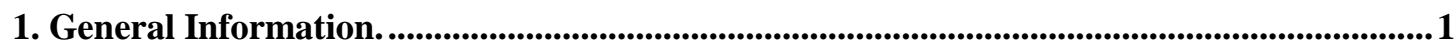

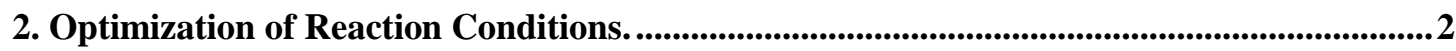

3. General Procedure and Product Characterization Data for Acyl Fluorides 1........................6

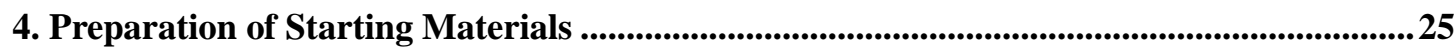

5. Detection of $\mathrm{O}_{2}$ in the Process of Oxidative Fluorination Reaction of Carboxylic Acids....26

6. The Linear Relationship between Yield and ReactionTime of 2a.............................................27

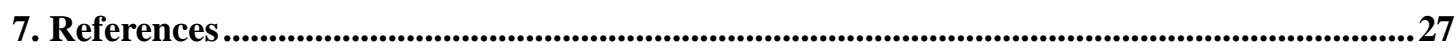

8. ${ }^{1} \mathrm{H}$ NMR Spectra, ${ }^{19}$ F NMR Spectra and ${ }^{13} \mathrm{C}$ NMR Spectra.......................................................28 


\section{General Information.}

All reagents were used as received from commercial sources, unless specified otherwise. All reactions were performed in narrow-mouth FEP tube $\left(\right.$ Nalgene $\left.{ }^{\circledR}\right)$. All reactions were monitored by thin-layer chromatography (TLC) carried out on $0.25 \mathrm{~mm}$ Merck silica-gel (60-F254). The TLC plates were visualized with UV light (254 nm) and potassium permanganate or $p$-anisaldehyde in ethanol/heat. Purification of reaction products was carried out by column chromatography with silica-gel $60 \mathrm{~N}$ spherical neutral size $63-210 \mu \mathrm{m}$ or $40-63 \mu \mathrm{m}$. Unless otherwise specified, the ${ }^{1} \mathrm{H}-\mathrm{NMR}$ (300 MHz), ${ }^{19} \mathrm{~F}-\mathrm{NMR}(282 \mathrm{MHz}),{ }^{13} \mathrm{C}-\mathrm{NMR}(90 \mathrm{MHz}, 126 \mathrm{MHz}$ and $176 \mathrm{MHz}$ ) spectra for solution in $\mathrm{CDCl}_{3}$ were recorded on a Buruker Avance 500, Varian Mercury 300, JEOL ECZ700R. Chemical shifts ( $\delta$ ) are expressed in ppm downfield from tetramethylsilane $(\delta \mathrm{H}=0.00 \mathrm{ppm})$ or $\mathrm{CDCl}_{3}(\delta \mathrm{C}=77.0 \mathrm{ppm})$ or hexafluorobenzene ( $\delta \mathrm{F}=-162.20 \mathrm{ppm})$. Mass spectra $(\mathrm{MS})$ was recorded on a JEOL JMS-Q1050GC Master-Quad GC/MS (EI-MS) and SHIMADZU LCMS-2020 (ESI-MS). High resolution mass spectrometry (HRMS) was recorded on a Waters Synapt G2 HDMS (ESI-MS) and a SHIMADZU GCMS-QP5050A (EI-MS). The wave numbers $(v)$ of recorded IR-signals are quoted in $\mathrm{cm}^{-1}$ on a JASCO FT/IR-4100 spectrometer. Melting point was recorded on a BUCHI M-565. All solvents were dried and distilled before use. 


\section{Optimization of Reaction Conditions.}

Table S1. Optimization of reaction condition with $\mathbf{2 a}$.<smiles>O=C(O)c1ccccc1</smiles>

$2^{a}$

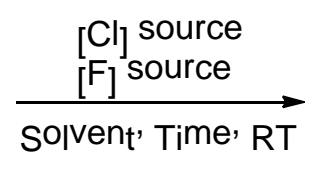

Solvent

(z mL)

$\operatorname{MeCN}(1)$

$\operatorname{MeCN}(1)$

MeCN (1)

MeCN (1)

$\operatorname{MeCN}(1)$

MeCN (1)

MeCN (1)

MeCN (1)

MeCN (1)

MeCN (1)

MeCN (1)

MeCN (1)

MeCN (1)

MeCN (0.5)

MeCN (0.5)

$\operatorname{MeCN}(0.5)$

$\operatorname{MeCN}(0.5)$

$\operatorname{MeCN}(0.4)$

MeCN (0.3)

$\operatorname{MeCN}(0.2)$

MeCN (0.1)

MeCN (0.5)

MeCN (0.5)<smiles>O=C(F)c1ccccc1</smiles>

$1 a$

\begin{tabular}{|c|c|c|c|c|c|}
\hline Entry & $\begin{array}{l}\text { [Cl] source } \\
\text { (x equiv) }\end{array}$ & $\begin{array}{l}{[\mathrm{F}] \text { source }} \\
\qquad \text { (y equiv) }\end{array}$ & $\begin{array}{l}\text { Solvent } \\
\qquad(\mathrm{z} \mathrm{mL})\end{array}$ & $\begin{array}{l}\text { Time } \\
\text { (h) }\end{array}$ & Yield (\%) ${ }^{a}$ \\
\hline 1 & TCCA (2) & KF (2) & MeCN (1) & 24 & 2 \\
\hline 2 & TCCA (2) & $\mathrm{KF}(4)$ & MeCN (1) & 24 & 5 \\
\hline 3 & TCCA (4) & KF (8) & MeCN (1) & 24 & 3 \\
\hline 4 & TCCA (8) & KF (8) & MeCN (1) & 24 & 12 \\
\hline 5 & TCCA (8) & CsF (8) & MeCN (1) & 24 & 38 \\
\hline 6 & TCCA (8) & CsF (4) & MeCN (1) & 24 & 28 \\
\hline 7 & TCCA (8) & CsF (2) & MeCN (1) & 24 & 7 \\
\hline 8 & TCCA (4) & CsF (8) & $\operatorname{MeCN}(1)$ & 24 & 50 \\
\hline 9 & TCCA (3) & CsF (8) & MeCN (1) & 24 & 70 \\
\hline 10 & TCCA (2.5) & CsF (8) & MeCN (1) & 24 & 67 \\
\hline 11 & TCCA (2) & CsF (8) & MeCN (1) & 24 & 79 \\
\hline 12 & TCCA (1.5) & CsF (8) & MeCN (1) & 24 & 37 \\
\hline 13 & TCCA $(1,5)$ & CsF (4) & MeCN (1) & 24 & 12 \\
\hline 14 & TCCA (2) & CsF (8) & MeCN (0.5) & 24 & 92 \\
\hline $15^{b}$ & TCCA (2) & CsF (8) & $\operatorname{MeCN}(0.5)$ & 24 & 12 \\
\hline 16 & TCCA (2) & $\operatorname{CsF}(6)$ & $\operatorname{MeCN}(0.5)$ & 24 & 86 \\
\hline 17 & TCCA (2) & CsF (4) & $\operatorname{MeCN}(0.5)$ & 24 & 15 \\
\hline 18 & TCCA (2) & CsF (8) & $\mathrm{MeCN}(0.4)$ & 24 & 86 \\
\hline 19 & TCCA (2) & CsF (8) & $\operatorname{MeCN}(0.3)$ & 24 & 70 \\
\hline 20 & TCCA (2) & CsF (8) & $\operatorname{MeCN}(0.2)$ & 24 & 58 \\
\hline 21 & TCCA (2) & CsF (8) & $\operatorname{MeCN}(0.1)$ & 24 & 54 \\
\hline 22 & NCS (2) & CsF (8) & $\operatorname{MeCN}(0.5)$ & 24 & ND \\
\hline 23 & $\mathrm{Ph}_{3} \mathrm{PCl}_{2}(2)$ & CsF (8) & $\operatorname{MeCN}(0.5)$ & 24 & 30 \\
\hline
\end{tabular}




\begin{tabular}{|c|c|c|c|c|c|}
\hline 24 & DCDMH (2) & CsF (8) & MeCN (0.5) & 24 & ND \\
\hline 25 & TCCA (2) & $\operatorname{LiF}(8)$ & $\operatorname{MeCN}(0.5)$ & 24 & ND \\
\hline 26 & TCCA (2) & $\mathrm{NaF}(8)$ & $\operatorname{MeCN}(0.5)$ & 24 & ND \\
\hline 27 & TCCA (2) & $\mathrm{KHF}_{2}(8)$ & MeCN (0.5) & 24 & ND \\
\hline 28 & TCCA (2) & KF (8) & MeCN (0.5) & 24 & 23 \\
\hline 29 & TCCA (2) & CsF (8) & DMSO (0.5) & 24 & ND \\
\hline 30 & TCCA (2) & CsF (8) & DMF (0.5) & 24 & 49 \\
\hline 31 & TCCA (2) & CsF (8) & THF (0.5) & 24 & ND \\
\hline 32 & TCCA (2) & CsF (8) & Toluene (0.5) & 24 & ND \\
\hline 33 & TCCA (2) & CsF (8) & acetone (0.5) & 24 & ND \\
\hline 34 & TCCA (2) & CsF (8) & $\mathrm{Et}_{2} \mathrm{O}(0.5)$ & 24 & ND \\
\hline 35 & TCCA (2) & CsF (8) & 1,4- dioxane (0.5) & 24 & 1 \\
\hline 36 & TCCA (2) & CsF (8) & $\operatorname{DCM}(0.5)$ & 24 & ND \\
\hline 37 & TCCA (2) & CsF (8) & MeCN (0.5) & 20 & 91 \\
\hline 38 & TCCA (2) & CsF (8) & MeCN (0.5) & 16 & 84 \\
\hline 39 & TCCA (2) & CsF (4) & MeCN (0.5) & 12 & 77 \\
\hline 40 & TCCA (2) & CsF (8) & MeCN (0.5) & 8 & 10 \\
\hline 41 & TCCA (2) & CsF (8) & MeCN (0.5) & 4 & 4 \\
\hline $42^{c}$ & TCCA (2) & CsF (2) & MeCN (0.5) & 24 & ND \\
\hline $43^{c}$ & TCCA (2) & CsF (1) & MeCN (0.5) & 24 & ND \\
\hline $44^{\mathrm{c}}$ & TCCA (2) & CsF (8) & MeCN (0.5) & 16 & 84 \\
\hline
\end{tabular}

Standard conditons:2a $(0.1 \mathrm{mmol}),[\mathrm{Cl}]$ source and [F] source in solvent at room temperature. ${ }^{\mathrm{a} D e t e r m i n e d ~ b y ~}{ }^{19} \mathrm{~F}$ NMR spectroscopy. ${ }^{b}$ Without glovebox ${ }^{\mathrm{c}} 20$ mol\% TBAB was used

Table S2. Optimization of reaction condition with $\mathbf{2 g}$.

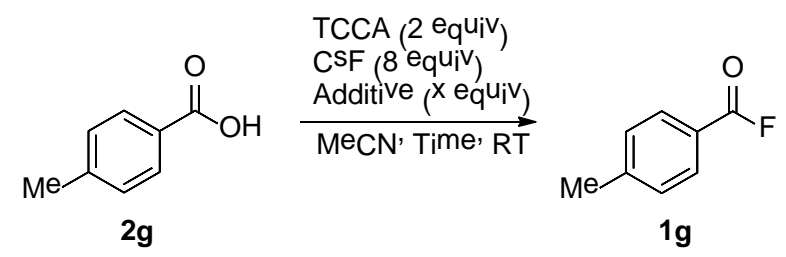

$\begin{array}{llll} & \text { Additive } & \text { Time } & \text { Yield (\%) }{ }^{a} \\ 1 & \text { (x equiv) } & \text { (h) } & \\ 2 & - & 24 & 13 \\ & \text { TFA (0.1) } & 24 & 9\end{array}$




\begin{tabular}{|c|c|c|c|}
\hline 3 & TFA $(0.2)$ & 24 & 6 \\
\hline 4 & TFA (1) & 24 & 1 \\
\hline 5 & $\mathrm{PPh}_{3}(0.1)$ & 24 & 11 \\
\hline 6 & $\mathrm{PPh}_{3}(0.2)$ & 24 & 12 \\
\hline 7 & $\mathrm{PPh}_{3}(1)$ & 24 & 60 \\
\hline 8 & $\mathrm{PPh}_{3}(1.2)$ & 24 & 64 \\
\hline 9 & $\mathrm{PPh}_{3}(1.5)$ & 24 & 89 \\
\hline 10 & $\mathrm{PPh}_{3}(2)$ & 24 & 94 \\
\hline 11 & $\mathrm{PPh}_{3}(2.5)$ & 24 & 94 \\
\hline 12 & $\mathrm{PPh}_{3}(2)$ & 2 & 77 \\
\hline 13 & $\mathrm{PPh}_{3}(2)$ & 3 & 84 \\
\hline 14 & $\mathrm{PPh}_{3}(2)$ & 5 & 85 \\
\hline 15 & $\mathrm{PPh}_{3}(2)$ & 12 & 84 \\
\hline 16 & $\mathrm{PPh}_{3}(2)$ & 20 & 94 \\
\hline 17 & DBU (2) & 24 & ND \\
\hline 18 & $\mathrm{Et}_{3} \mathrm{~N}(2)$ & 24 & ND \\
\hline 19 & $\mathrm{Cs}_{2} \mathrm{CO}_{3}(2)$ & 24 & ND \\
\hline 20 & $\mathrm{~K}_{3} \mathrm{PO}_{4}$ & 24 & ND \\
\hline 21 & $\mathrm{NaOAc}$ & 24 & ND \\
\hline 22 & $\mathrm{KOH}$ & 24 & trace \\
\hline
\end{tabular}

Standard conditons:2g (0.2 mmol), TCCA (2 equiv) and CsF (8 equiv) in MeCN (1 mL) at room temperature.

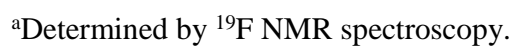

Table S3. Optimization of reaction condition with 4c.

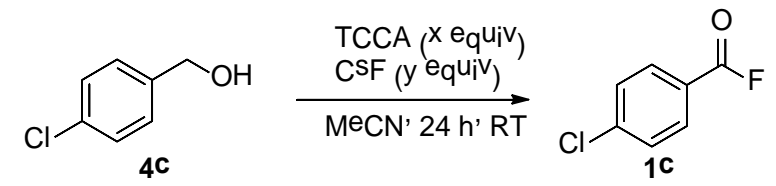

$\begin{array}{lcccc}\text { Entry } & \text { TCCA } & \text { CsF } & \text { Yield (\%) } \\ & 2 & & \text { (y equiv) } & \\ 1 & & 8 & 44 \\ 2 & 2 & 10 & 54\end{array}$


6

3

9

81

7

3

10

96

Standard conditons:4c $(0.2 \mathrm{mmol})$, TCCA and CsF in MeCN $(1 \mathrm{~mL})$ at room temperature. ${ }^{\text {aDetermined by }}{ }^{19} \mathrm{~F}$ NMR spectroscopy. 


\section{General Procedure and Product Characterization Data for Acyl Fluorides 1}

\section{General procedure A:}<smiles>[R]C(=O)O</smiles>

2

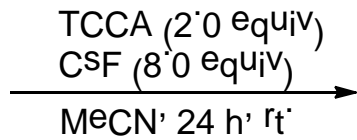

MeCN' 24 h' rt<smiles>[R]C(=O)F</smiles>

1

An oven-dried narrow-mouth FEP tube (Nalgene $\left.{ }^{\circledR}\right)(10.0 \mathrm{~mL})$ containing a magnetic stir bar was charged with carboxylic acid (2, $0.2 \mathrm{mmol}$ ), trichloroisocyanuric acid (TCCA, $93.0 \mathrm{mg}, 0.4 \mathrm{mmol}, 2.0$ equiv) and cesium fluoride (CsF, $243.0 \mathrm{mg}, 1.6 \mathrm{mmol}$, 8.0 equiv) in anhydrous acetonitrile (MeCN, $1.0 \mathrm{~mL}, 0.2 \mathrm{M}$ ) in a nitrogenfilled glovebox. The tube was tightly sealed and taken out of the glove box, then stirred at room temperature for 24 hours. Yields were determined by ${ }^{19} \mathrm{~F}$ NMR analysis of the crude products using $\mathrm{C}_{6} \mathrm{H}_{5} \mathrm{~F}(19.0 \mu \mathrm{L}, 0.2$ mmol, 1.0 equiv) as an internal standard. The crude mixture was directly purified by silica gel flash chromatography (5 cm thick $\times 2 \mathrm{~cm}$ diameter) or washed with Hexane/DCM $(9: 1,5 \mathrm{~mL} \times 2)$, to afford the desired compound $\mathbf{1}$.

\section{General procedure B:}<smiles>[R]C(=O)O</smiles>

2

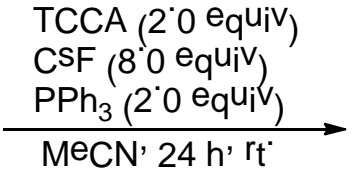

MeCN' $24 h^{\prime} r^{\prime}$<smiles>[R]C(=O)F</smiles>

An oven-dried narrow-mouth FEP tube $\left(\right.$ Nalgene $\left.{ }^{\circledR}\right)(10.0 \mathrm{~mL})$ containing a magnetic stir bar was charged with carboxylic acid (2, $0.2 \mathrm{mmol})$, triphenylphosphine ( $\mathrm{PPh}_{3}, 104.9 \mathrm{mg}, 0.4 \mathrm{mmol}, 2.0$ equiv), trichloroisocyanuric acid (TCCA, $93.0 \mathrm{mg}, 0.4 \mathrm{mmol}, 2.0$ equiv) and cesium fluoride (CsF, $243.0 \mathrm{mg}, 1.6 \mathrm{mmol}, 8.0$ equiv) in anhydrous acetonitrile (MeCN, $1.0 \mathrm{~mL}, 0.2 \mathrm{M}$ ) in a nitrogen-filled glovebox. The tube was tightly sealed and taken out of the glove box, then stirred at room temperature for 24 hours. Yields were determined by ${ }^{19} \mathrm{~F}$ NMR analysis of the crude products using $\mathrm{C}_{6} \mathrm{H}_{5} \mathrm{~F}(19.0 \mu \mathrm{L}, 0.2 \mathrm{mmol}, 1.0$ equiv) as an internal standard. The crude mixture was directly purified by silica gel flash chromatography ( $5 \mathrm{~cm}$ thick $\times 2 \mathrm{~cm}$ diameter) to afford the desired compound $\mathbf{1}$.

\section{General procedure C:}<smiles>[R]C=O</smiles>

3

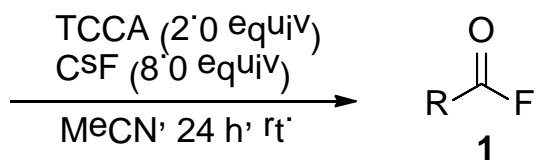

An oven-dried narrow-mouth FEP tube (Nalgene $\left.{ }^{\circledR}\right)(10.0 \mathrm{~mL})$ containing a magnetic stir bar was charged with aldehyde (3, $0.2 \mathrm{mmol}$ ), trichloroisocyanuric acid (TCCA, $93.0 \mathrm{mg}, 0.4 \mathrm{mmol}, 2.0$ equiv) and cesium fluoride (CsF, $243.0 \mathrm{mg}, 1.6 \mathrm{mmol}, 8.0$ equiv) in anhydrous acetonitrile (MeCN, $1.0 \mathrm{~mL}, 0.2 \mathrm{M}$ ) in a nitrogen-filled glovebox. The tube was tightly sealed and taken out of the glove box, then stirred at room temperature for 24 hours. Yields were determined by ${ }^{19} \mathrm{~F}$ NMR analysis of the crude products using $\mathrm{C}_{6} \mathrm{H}_{5} \mathrm{~F}(19.0 \mu \mathrm{L}, 0.2 \mathrm{mmol}$, 
1.0 equiv) as an internal standard. The crude mixture was directly purified by silica gel flash chromatography (5 $\mathrm{cm}$ thick $\times 2 \mathrm{~cm}$ diameter) or washed with Hexane/DCM (9:1, $5 \mathrm{~mL} \times 2$ ), to afford the desired compound 1.

\section{General procedure D:}

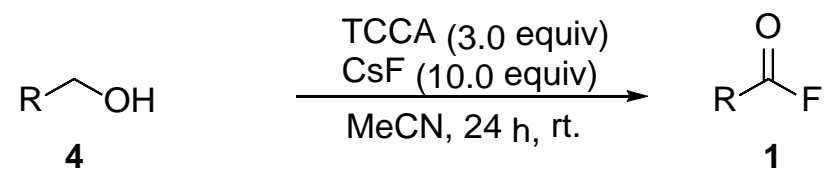

An oven-dried narrow-mouth FEP tube (Nalgene $\left.{ }^{\circledR}\right)(10.0 \mathrm{~mL})$ containing a magnetic stir bar was charged with alcohol (4, $0.2 \mathrm{mmol})$, trichloroisocyanuric acid (TCCA, $139.4 \mathrm{mg}, 0.6 \mathrm{mmol}, 3.0$ equiv) and cesium fluoride (CsF, $303.8 \mathrm{mg}, 2.0 \mathrm{mmol}, 10.0$ equiv) in anhydrous acetonitrile (MeCN, $1.0 \mathrm{~mL}, 0.2 \mathrm{M}$ ) in a nitrogen-filled glovebox. The tube was tightly sealed and taken out of the glove box, then stirred at room temperature for 24 hours. Yields were determined by ${ }^{19} \mathrm{~F}$ NMR analysis of the crude products using $\mathrm{C}_{6} \mathrm{H}_{5} \mathrm{~F}(19.0 \mu \mathrm{L}, 0.2 \mathrm{mmol}$, 1.0 equiv) as an internal standard. The crude mixture was directly purified by silica gel flash chromatography (5 $\mathrm{cm}$ thick $\times 2 \mathrm{~cm}$ diameter) or washed with Hexane/DCM $(9: 1,5 \mathrm{~mL} \times 2)$, to afford the desired compound 1.<smiles>O=C(F)c1ccccc1</smiles>

\section{Benzoyl fluoride (1a).}

From carboxylic acids: Following the general procedure A, using substrate 2a (0.2 mmol, 1.0 equiv), TCCA (93.0 mg, $0.4 \mathrm{mmol}, 2.0$ equiv) and CsF (243.0 mg, $1.6 \mathrm{mmol}, 8.0$ equiv) in MeCN (1.0 mL), the reaction mixture was stirred at rt for 24 hours. The yield (92\%) was determined by ${ }^{19} \mathrm{~F}$ NMR of the crude reaction mixture. The crude mixture was purified by column chromatography (n-Pentane: $\mathrm{Et}_{2} \mathrm{O}=20: 1$ ) to afford the title compound 1a (15.6 mg, 63\% yield) as a colorless oil.

From aldehydes: Following the general procedure $\mathbf{C}$, using substrate 3a (0.2 mmol, 1.0 equiv), TCCA (93.0 mg, $0.4 \mathrm{mmol}, 2.0$ equiv) and CsF (243.0 mg, $1.6 \mathrm{mmol}$, 8.0 equiv) in MeCN (1.0 mL), the reaction mixture was stirred at rt for 24 hours. The yield (92\%) was determined by ${ }^{19} \mathrm{~F}$ NMR of the crude reaction mixture. The crude mixture was purified by column chromatography ( $n$-Pentane: $\mathrm{Et}_{2} \mathrm{O}=20: 1$ ) to afford the title compound 1a (16.6 mg, 67\% yield) as a colorless oil.

From alcohols: Following the general procedure D, using substrate 4a (0.2 mmol, 1.0 equiv), TCCA (139.4 mg, $0.6 \mathrm{mmol}$, 3.0 equiv) and CsF (303.8 mg, $2.0 \mathrm{mmol}, 10.0$ equiv) in MeCN (1.0 mL), the reaction mixture was stirred at rt for 24 hours. The yield (80\%) was determined by ${ }^{19} \mathrm{~F}$ NMR of the crude reaction mixture. The crude mixture was purified by column chromatography ( $n$-Pentane: $\mathrm{Et}_{2} \mathrm{O}=20: 1$ ) to afford the title compound 1a (12.1 mg, 49\% yield) as a colorless oil.

${ }^{1} \mathbf{H}$ NMR (300 MHz, CDCl 3 ) $\delta: 8.07-8.03$ (m, 2H), $7.74-7.68$ (m, 1H), $7.56-7.50$ (m, 2H) ppm. ${ }^{19}$ F NMR $\left(282 \mathrm{MHz}, \mathrm{CDCl}_{3}\right) \delta: 17.63$ (s, 1F) ppm. MS (EI): m/z $124[\mathrm{M}]^{+}$. Spectroscopic data was agreement with the 
literature. ${ }^{1}$<smiles>O=C(F)c1ccc(F)cc1</smiles>

\section{4-Fluorobenzoyl fluoride (1b).}

From carboxylic acids: Following the general procedure A, using substrate $\mathbf{2 b}$ ( $0.2 \mathrm{mmol}, 1.0$ equiv), TCCA (93.0 mg, $0.4 \mathrm{mmol}, 2.0$ equiv) and CsF (243.0 mg, $1.6 \mathrm{mmol}$, 8.0 equiv) in MeCN (1.0 mL), the reaction mixture was stirred at rt for 24 hours. The yield (88\%) was determined by ${ }^{19} \mathrm{~F}$ NMR of the crude reaction mixture. The crude mixture was purified by column chromatography ( $n$-Pentane: $\mathrm{Et}_{2} \mathrm{O}=50: 1$ ) to afford the title compound $\mathbf{1 b}$ (19.3 $\mathrm{mg}$, 68\% yield) as a colorless oil.

From aldehydes: Following the general procedure $\mathbf{C}$, using substrate $\mathbf{3 b}$ ( $0.2 \mathrm{mmol}$, 1.0 equiv), TCCA (93.0 mg, $0.4 \mathrm{mmol}$, 2.0 equiv) and CsF (243.0 mg, $1.6 \mathrm{mmol}$, 8.0 equiv) in MeCN (1.0 mL), the reaction mixture was stirred at rt for 24 hours. The yield (>99\%) was determined by ${ }^{19} \mathrm{~F}$ NMR of the crude reaction mixture. The crude mixture was purified by column chromatography ( $n$-Pentane: $\left.\mathrm{Et}_{2} \mathrm{O}=50: 1\right)$ to afford the title compound $\mathbf{1 b}$ (15.1 mg, 53\% yield) as a colorless oil.

From alcohols: Following the general procedure $\mathbf{D}$, using substrate $\mathbf{4 b}$ ( $0.2 \mathrm{mmol}$, 1.0 equiv), TCCA (139.4 mg, $0.6 \mathrm{mmol}, 3.0$ equiv) and CsF (303.8 mg, $2.0 \mathrm{mmol}, 10.0$ equiv) in MeCN (1.0 mL), the reaction mixture was stirred at rt for 24 hours. The yield (72\%) was determined by ${ }^{19} \mathrm{~F}$ NMR of the crude reaction mixture. The crude mixture was purified by column chromatography ( $n$-Pentane: $\left.\mathrm{Et}_{2} \mathrm{O}=50: 1\right)$ to afford the title compound 1b (12.2 mg, 43\% yield) as a colorless oil.

${ }^{1} \mathbf{H}$ NMR (300 MHz, $\left.\mathrm{CDCl}_{3}\right) \delta: 8.11-8.06$ (m, 2H), 7.26 - 7.18 (m, 2H) ppm. ${ }^{19} \mathbf{F}$ NMR (282 MHz, $\left.\mathrm{CDCl}_{3}\right)$ $\delta: 17.52$ (s, 1F), -100.02 - -102.32 (m, 1F) ppm. MS (EI): m/z $142[\mathrm{M}]^{+}$. Spectroscopic data was agreement with the literature. ${ }^{1}$<smiles>O=C(F)c1ccc(Cl)cc1</smiles>

\section{4-Chlorobenzoyl fluoride (1c).}

From carboxylic acids: Following the general procedure A, using substrate $2 \mathbf{c}(0.2 \mathrm{mmol}, 1.0$ equiv), TCCA (93.0 mg, $0.4 \mathrm{mmol}, 2.0$ equiv) and CsF (243.0 mg, $1.6 \mathrm{mmol}$, 8.0 equiv) in MeCN (1.0 mL), the reaction mixture was stirred at rt for 24 hours. The yield (>99\%) was determined by ${ }^{19} \mathrm{~F}$ NMR of the crude reaction mixture. The crude mixture was purified by column chromatography $(n$-Hexane: EtOAc $=20: 1)$ to afford the title compound 1c (27.3 mg, 86\% yield) as a pale yellow solid.

From aldehydes: Following the general procedure $\mathbf{C}$, using substrate $3 \mathbf{c}$ ( $0.2 \mathrm{mmol}$, 1.0 equiv), TCCA (93.0 mg, $0.4 \mathrm{mmol}$, 2.0 equiv) and CsF (243.0 mg, $1.6 \mathrm{mmol}$, 8.0 equiv) in MeCN (1.0 mL), the reaction mixture was stirred at rt for 24 hours. The yield (>99\%) was determined by ${ }^{19} \mathrm{~F}$ NMR of the crude reaction mixture. 
The crude mixture was purified by column chromatography ( $n$-Hexane: EtOAc $=20: 1)$ to afford the title compound 1c (26.3 mg, 83\% yield) as a pale yellow solid.

From alcohols: Following the general procedure D, using substrate 4c (0.2 mmol, 1.0 equiv), TCCA (139.4 mg, $0.6 \mathrm{mmol}$, 3.0 equiv) and CsF (303.8 mg, $2.0 \mathrm{mmol}, 10.0$ equiv) in MeCN (1.0 mL), the reaction mixture was stirred at rt for 24 hours. The yield (96\%) was determined by ${ }^{19} \mathrm{~F}$ NMR of the crude reaction mixture. The crude mixture was purified by column chromatography ( $n$-Hexane: EtOAc $=20: 1$ ) to afford the title compound 1c (24.4 mg, 77\% yield) as a pale yellow solid.

${ }^{1} \mathbf{H}$ NMR $\left(300 \mathrm{MHz}, \mathrm{CDCl}_{3}\right) \delta: 7.99(\mathrm{dd}, J=8.7,2.4 \mathrm{~Hz}, 2 \mathrm{H}), 7.51(\mathrm{~d}, J=7.0 \mathrm{~Hz}, 2 \mathrm{H}) \mathrm{ppm} .{ }^{\mathbf{1 9}} \mathbf{F}$ NMR $(282$ $\mathrm{MHz}_{\mathrm{CDCl}}$ ) $\delta: 17.91$ (s, 1F) ppm. MS (EI): m/z $158[\mathrm{M}]^{+}$. Spectroscopic data was agreement with the literature. $^{1}$<smiles>O=C(F)c1ccc(Br)cc1</smiles>

\section{4-Bromobenzoyl fluoride (1d).}

From carboxylic acids: Following the general procedure A, using substrate 2d (0.2 mmol, 1.0 equiv), TCCA (93.0 mg, $0.4 \mathrm{mmol}, 2.0$ equiv) and CsF (243.0 mg, $1.6 \mathrm{mmol}, 8.0$ equiv) in MeCN (1.0 mL), the reaction mixture was stirred at rt for 24 hours. The yield (93\%) was determined by ${ }^{19} \mathrm{~F}$ NMR of the crude reaction mixture. The crude mixture was purified by column chromatography ( $n$-Hexane: EtOAc $=20: 1)$ to afford the title compound 1d (32.9 mg, 81\% yield) as a white solid.

From aldehydes: Following the general procedure C, using substrate 3d (0.2 mmol, 1.0 equiv), TCCA (93.0 mg, $0.4 \mathrm{mmol}$, 2.0 equiv) and CsF (243.0 mg, $1.6 \mathrm{mmol}$, 8.0 equiv) in MeCN (1.0 mL), the reaction mixture was stirred at rt for 24 hours. The yield (>99\%) was determined by ${ }^{19} \mathrm{~F} \mathrm{NMR}$ of the crude reaction mixture. The crude mixture was purified by column chromatography ( $n$-Hexane: EtOAc $=20: 1$ ) to afford the title compound 1d (34.2 mg, 84\% yield) as a white solid.

From alcohols: Following the general procedure D, using substrate 4d (0.2 mmol, 1.0 equiv), TCCA (139.4 mg, $0.6 \mathrm{mmol}$, 3.0 equiv) and CsF (303.8 mg, $2.0 \mathrm{mmol}, 10.0$ equiv) in MeCN (1.0 mL), the reaction mixture was stirred at rt for 24 hours. The yield (>99\%) was determined by ${ }^{19} \mathrm{~F}$ NMR of the crude reaction mixture. The crude mixture was purified by column chromatography ( $n$-Hexane: EtOAc $=20: 1)$ to afford the title compound 1d (33.7 $\mathrm{mg}, 83 \%$ yield) as a white solid.

${ }^{1} \mathbf{H}$ NMR $\left(300 \mathrm{MHz}, \mathrm{CDCl}_{3}\right) \delta: 7.91(\mathrm{~d}, J=8.6 \mathrm{~Hz}, 2 \mathrm{H}), 7.70-7.67$ (m, 2H) ppm. ${ }^{19} \mathbf{F}$ NMR $(282 \mathrm{MHz}$, $\left.\mathrm{CDCl}_{3}\right) \delta: 17.91$ (s, 1F) ppm. MS (EI): m/z $202[\mathrm{M}]^{+}$. Spectroscopic data was agreement with the literature. ${ }^{1}$<smiles>O=C(F)c1ccc([N+](=O)[O-])cc1</smiles>

4-Nitrobenzoyl fluoride (1e). 
From carboxylic acids: Following the general procedure A, using substrate $\mathbf{2 e}$ (0.2 mmol, 1.0 equiv), TCCA (93.0 mg, $0.4 \mathrm{mmol}, 2.0$ equiv) and CsF (243.0 mg, $1.6 \mathrm{mmol}, 8.0$ equiv) in MeCN (1.0 mL), the reaction mixture was stirred at rt for 24 hours. The yield (>99\%) was determined by ${ }^{19} \mathrm{~F}$ NMR of the crude reaction mixture. The crude mixture was washed with Hexane $(5 \mathrm{~mL} \times 2)$ to afford the title compound 1 e $(16.9 \mathrm{mg}$, $50 \%$ yield) as a white solid.

From aldehydes: Following the general procedure $\mathbf{C}$, using substrate $3 \mathbf{e}$ (0.2 mmol, 1.0 equiv), TCCA (93.0 mg, $0.4 \mathrm{mmol}$, 2.0 equiv) and CsF (243.0 mg, $1.6 \mathrm{mmol}, 8.0$ equiv) in MeCN (1.0 mL), the reaction mixture was stirred at rt for 24 hours. The yield (89\%) was determined by ${ }^{19} \mathrm{~F}$ NMR of the crude reaction mixture. The crude mixture was purified by column chromatography ( $n$-Hexane: EtOAc $=20: 1)$ to afford the title compound 1e (21.7 mg, 63\% yield) as a white solid.

From alcohols: Following the general procedure D, using substrate 4e (0.2 mmol, 1.0 equiv), TCCA (139.4 mg, $0.6 \mathrm{mmol}, 3.0$ equiv) and CsF (303.8 mg, $2.0 \mathrm{mmol}, 10.0$ equiv) in MeCN (1.0 mL), the reaction mixture was stirred at rt for 24 hours. The yield (89\%) was determined by ${ }^{19} \mathrm{~F}$ NMR of the crude reaction mixture. The crude mixture was purified by column chromatography ( $n$-Hexane: EtOAc $=20: 1)$ to afford the title compound 1e (20.3 $\mathrm{mg}, 60 \%$ yield) as a white solid.

${ }^{1} \mathbf{H}$ NMR $\left(300 \mathrm{MHz}, \mathrm{CDCl}_{3}\right) \delta: 8.40(\mathrm{~d}, J=8.8 \mathrm{~Hz}, 2 \mathrm{H}), 8.26(\mathrm{~d}, J=8.8 \mathrm{~Hz}, 2 \mathrm{H}) \mathrm{ppm} .{ }^{\mathbf{1 9}} \mathbf{F} \mathbf{~ N M R}(282 \mathrm{MHz}$, $\left.\mathrm{CDCl}_{3}\right) \delta: 20.85$ (s, 1F) ppm. MS (EI): m/z $169[\mathrm{M}]^{+}$. Spectroscopic data was agreement with the literature. ${ }^{2}$<smiles>O=C(F)c1ccc(C(F)(F)F)cc1</smiles>

\section{4-(Trifluoromethyl)benzoyl fluoride fluoride (1f).}

From carboxylic acids: Following the general procedure A, using substrate $2 \mathbf{f}$ ( $0.2 \mathrm{mmol}, 1.0$ equiv), TCCA (93.0 mg, $0.4 \mathrm{mmol}, 2.0$ equiv) and CsF (243.0 mg, $1.6 \mathrm{mmol}, 8.0$ equiv) in MeCN (1.0 mL), the reaction mixture was stirred at rt for 24 hours. The yield (83\%) was determined by ${ }^{19} \mathrm{~F}$ NMR of the crude reaction mixture. The crude mixture was purified by column chromatography ( $n$-Pentane: $\mathrm{Et}_{2} \mathrm{O}=50: 1$ ) to afford the title compound $\mathbf{1 f}$ (21.9 mg, 57\% yield) as a colorless oil.

From aldehydes: Following the general procedure $\mathbf{C}$, using substrate $\mathbf{3 f}$ (0.2 mmol, 1.0 equiv), TCCA (93.0 mg, $0.4 \mathrm{mmol}$, 2.0 equiv) and CsF (243.0 mg, $1.6 \mathrm{mmol}, 8.0$ equiv) in MeCN (1.0 mL), the reaction mixture was stirred at rt for 24 hours. The yield (96\%) was determined by ${ }^{19} \mathrm{~F}$ NMR of the crude reaction mixture. The crude mixture was purified by column chromatography ( $n$-Pentane: $\mathrm{Et}_{2} \mathrm{O}=50: 1$ ) to afford the title compound 1f (30.8 mg, 80\% yield) as a colorless oil.

From alcohols: Following the general procedure D, using substrate $4 \mathbf{f}$ ( $0.2 \mathrm{mmol}$, 1.0 equiv), TCCA (139.4 mg, $0.6 \mathrm{mmol}$, 3.0 equiv) and CsF (303.8 mg, $2.0 \mathrm{mmol}, 10.0$ equiv) in MeCN (1.0 mL), the reaction mixture was stirred at rt for 24 hours. The yield (94\%) was determined by ${ }^{19} \mathrm{~F}$ NMR of the crude reaction mixture. The crude mixture was purified by column chromatography ( $n$-Pentane: $\mathrm{Et}_{2} \mathrm{O}=50: 1$ ) to afford the title compound 1f (21.5 mg, 56\% yield) as a colorless oil. 
${ }^{1} \mathbf{H}$ NMR $\left(300 \mathrm{MHz}, \mathrm{CDCl}_{3}\right) \delta: 8.19(\mathrm{~d}, J=8.2 \mathrm{~Hz}, 2 \mathrm{H}), 7.82(\mathrm{~d}, J=8.1 \mathrm{~Hz}, 2 \mathrm{H}) \mathrm{ppm} .{ }^{19} \mathbf{F}$ NMR $(282 \mathrm{MHz}$, $\left.\mathrm{CDCl}_{3}\right) \delta: 19.50(\mathrm{~s}, 1 \mathrm{~F}),-63.97$ (s, 3F) ppm. MS (EI): m/z $192[\mathrm{M}]^{+}$. Spectroscopic data was agreement with the literature. ${ }^{1}$<smiles>Cc1ccc(C(=O)F)cc1</smiles>

\section{4-Methylbenzoyl fluoride (1g).}

From carboxylic acids: Following the general procedure $\mathbf{B}$, using substrate $\mathbf{2 g}$ (0.2 mmol, 1.0 equiv), $\mathrm{PPh}_{3}$ (104.9 mg, 0.4 mmol, 2.0 equiv), TCCA (93.0 mg, 0.4 mmol, 2.0 equiv) and CsF (243.0 mg, 1.6 mmol, 8.0 equiv) in MeCN (1.0 mL), the reaction mixture was stirred at rt for 24 hours. The yield (95\%) was determined by ${ }^{19} \mathrm{~F}$ NMR of the crude reaction mixture. The crude mixture was purified by column chromatography ( $n$ Pentane: $\left.\mathrm{Et}_{2} \mathrm{O}=50: 1\right)$ to afford the title compound $1 \mathrm{~g}$ (23.2 mg, 84\% yield) as a colorless oil.

From aldehydes: Following the general procedure $\mathbf{C}$, using substrate $\mathbf{3 g}$ (0.2 mmol, 1.0 equiv), TCCA (93.0 mg, $0.4 \mathrm{mmol}, 2.0$ equiv) and CsF (243.0 mg, $1.6 \mathrm{mmol}, 8.0$ equiv) in MeCN (1.0 mL), the reaction mixture was stirred at rt for 24 hours. The yield (89\%) was determined by ${ }^{19} \mathrm{~F}$ NMR of the crude reaction mixture. The crude mixture was purified by column chromatography ( $n$-Pentane: $\mathrm{Et}_{2} \mathrm{O}=50: 1$ ) to afford the title compound $1 \mathrm{~g}$ (19.6 mg, 71\% yield) as a colorless oil.

From alcohols: Following the general procedure D, using substrate $\mathbf{4 g}$ (0.2 mmol, 1.0 equiv), TCCA (139.4 mg, $0.6 \mathrm{mmol}$, 3.0 equiv) and CsF (303.8 mg, $2.0 \mathrm{mmol}, 10.0$ equiv) in MeCN (1.0 mL), the reaction mixture was stirred at rt for 24 hours. The yield (38\%) was determined by ${ }^{19} \mathrm{~F}$ NMR of the crude reaction mixture. The crude mixture was purified by column chromatography ( $n$-Pentane: $\mathrm{Et}_{2} \mathrm{O}=50: 1$ ) to afford the title compound $1 \mathrm{~g}$ (4.7 mg, 17\% yield) as a colorless oil.

${ }^{1} \mathbf{H}$ NMR (300 MHz, $\mathrm{CDCl}_{3}$ ) $\delta: 7.91-7.45$ (m, 2H), 7.32 (d, J = $\left.7.9 \mathrm{~Hz}, 2 \mathrm{H}\right), 2.45$ (s, 3H) ppm. ${ }^{\mathbf{1 9}} \mathbf{F}$ NMR $\left(282 \mathrm{MHz}, \mathrm{CDCl}_{3}\right) \delta: 16.94$ (s, 1F) ppm. MS (EI): m/z $138[\mathrm{M}]^{+}$Spectroscopic data was agreement with the literature. $^{1}$<smiles>COc1ccc(C(=O)F)cc1</smiles>

\section{4-Methoxybenzoyl fluoride (1h).}

From carboxylic acids: Following the general procedure $\mathbf{B}$, using substrate $\mathbf{2 h}$ (0.2 mmol, 1.0 equiv), $\mathrm{PPh}_{3}$ (104.9 mg, $0.4 \mathrm{mmol}, 2.0$ equiv), TCCA (93.0 mg, $0.4 \mathrm{mmol}, 2.0$ equiv) and CsF (243.0 mg, $1.6 \mathrm{mmol}, 8.0$ equiv) in MeCN (1.0 mL), the reaction mixture was stirred at rt for 24 hours. The yield (68\%) was determined by ${ }^{19} \mathrm{~F}$ NMR of the crude reaction mixture. The crude mixture was purified by column chromatography ( $n$ Hexane: EtOAc = 20:1) to afford the title compound $\mathbf{1 h}(14.5 \mathrm{mg}, 47 \%$ yield $)$ as a white solid. 
${ }^{1} \mathbf{H}$ NMR (300 MHz, $\left.\mathrm{CDCl}_{3}\right) \delta: 8.00(\mathrm{~d}, J=8.8 \mathrm{~Hz}, 2 \mathrm{H}), 6.99$ (d, $\left.J=9.1 \mathrm{~Hz}, 2 \mathrm{H}\right), 3.90$ (s, 3H) ppm. ${ }^{19}$ F NMR $\left(282 \mathrm{MHz}, \mathrm{CDCl}_{3}\right) \delta: 15.46(\mathrm{~s}, 1 \mathrm{~F}) \mathrm{ppm}$. MS (EI): m/z $154[\mathrm{M}]^{+}$. Spectroscopic data was agreement with the literature. $^{1}$<smiles>O=C(F)c1ccc(-c2ccccc2)cc1</smiles>

\section{[1,1'-Biphenyl]-4-carbonyl fluoride (1i).}

From carboxylic acids: Following the general procedure A, using substrate $2 \mathbf{i}$ (0.2 mmol, 1.0 equiv), TCCA (93.0 mg, $0.4 \mathrm{mmol}, 2.0$ equiv) and CsF (243.0 mg, $1.6 \mathrm{mmol}, 8.0$ equiv) in MeCN (1.0 mL), the reaction mixture was stirred at rt for 24 hours. The yield (70\%) was determined by ${ }^{19} \mathrm{~F}$ NMR of the crude reaction mixture. The crude mixture was purified by column chromatography ( $n$-Hexane: EtOAc $=20: 1$ ) to afford the title compound $\mathbf{1 i}$ (21.2 $\mathrm{mg}, 53 \%$ yield) as a white solid.

From aldehydes: Following the general procedure $\mathbf{C}$, using substrate $3 \mathbf{i}$ ( $0.2 \mathrm{mmol}$, 1.0 equiv), TCCA (93.0 mg, $0.4 \mathrm{mmol}$, 2.0 equiv) and CsF (243.0 mg, $1.6 \mathrm{mmol}, 8.0$ equiv) in MeCN (1.0 mL), the reaction mixture was stirred at rt for 24 hours. The yield (97\%) was determined by ${ }^{19} \mathrm{~F}$ NMR of the crude reaction mixture. The crude mixture was purified by column chromatography ( $n$-Hexane: EtOAc $=20: 1)$ to afford the title compound $\mathbf{1 i}$ (33.3 mg, 83\% yield) as a white solid.

From alcohols: Following the general procedure D, using substrate $4 \mathbf{i}$ ( $0.2 \mathrm{mmol}$, 1.0 equiv), TCCA (139.4 mg, $0.6 \mathrm{mmol}$, 3.0 equiv) and CsF (303.8 mg, $2.0 \mathrm{mmol}, 10.0$ equiv) in MeCN (1.0 mL), the reaction mixture was stirred at rt for 24 hours. The yield (75\%) was determined by ${ }^{19} \mathrm{~F}$ NMR of the crude reaction mixture. The crude mixture was purified by column chromatography ( $n$-Hexane: EtOAc $=20: 1)$ to afford the title compound $1 \mathbf{i}$ (25.6 mg, 64\% yield) a white solid.

${ }^{1} \mathbf{H}$ NMR (300 MHz, $\left.\mathrm{CDCl}_{3}\right) \delta: 8.12$ (d, $\left.J=8.1 \mathrm{~Hz}, 2 \mathrm{H}\right), 7.74$ (d, $\left.J=8.0 \mathrm{~Hz}, 2 \mathrm{H}\right), 7.64(\mathrm{~d}, J=7.1 \mathrm{~Hz}, 2 \mathrm{H})$, 7.53 - 7.41 (m, 3H) ppm. ${ }^{19} \mathbf{F}$ NMR (282 MHz, $\left.\mathrm{CDCl}_{3}\right) \delta: 17.60$ (s, 1F) ppm. MS (EI): m/z 200 [M]. Spectroscopic data was agreement with the literature. ${ }^{1}$<smiles>CC(C)(C)c1ccc(C(=O)F)cc1</smiles>

\section{4-(tert-Butyl)benzoyl fluoride (1j).}

From carboxylic acids: Following the general procedure $\mathbf{B}$, using substrate $\mathbf{2 j}$ (0.2 mmol, 1.0 equiv), $\mathrm{PPh}_{3}$ (104.9 mg, 0.4 mmol, 2.0 equiv), TCCA (93.0 mg, 0.4 mmol, 2.0 equiv) and CsF (243.0 mg, $1.6 \mathrm{mmol}, 8.0$ equiv) in MeCN (1.0 mL), the reaction mixture was stirred at rt for 24 hours. The yield (86\%) was determined by ${ }^{19} \mathrm{~F}$ NMR of the crude reaction mixture. The crude mixture was purified by column chromatography ( $n$ Pentane: $\left.\mathrm{Et}_{2} \mathrm{O}=50: 1\right)$ to afford the title compound $\mathbf{1 j}$ (27.8 $\mathrm{mg}, 77 \%$ yield) as a colorless oil.

From aldehydes: Following the general procedure $\mathbf{C}$, using substrate $\mathbf{3 j}$ ( $0.2 \mathrm{mmol}$, 1.0 equiv), TCCA (93.0 
mg, $0.4 \mathrm{mmol}$, 2.0 equiv) and CsF (243.0 mg, $1.6 \mathrm{mmol}$, 8.0 equiv) in MeCN (1.0 mL), the reaction mixture was stirred at rt for 24 hours. The yield (56\%) was determined by ${ }^{19} \mathrm{~F}$ NMR of the crude reaction mixture. The crude mixture was purified by column chromatography ( $n$-Pentane: $\mathrm{Et}_{2} \mathrm{O}=50: 1$ ) to afford the title compound $\mathbf{1 j}$ (19.2 $\mathrm{mg}$, 53\% yield) as a colorless oil.

From alcohols: Following the general procedure D, using substrate $\mathbf{4 j}$ ( $0.2 \mathrm{mmol}$, 1.0 equiv), TCCA (139.4 mg, $0.6 \mathrm{mmol}$, 3.0 equiv) and CsF (303.8 mg, $2.0 \mathrm{mmol}, 10.0$ equiv) in MeCN (1.0 mL), the reaction mixture was stirred at rt for 24 hours. The yield (55\%) was determined by ${ }^{19} \mathrm{~F}$ NMR of the crude reaction mixture. The crude mixture was purified by column chromatography ( $n$-Pentane: $\mathrm{Et}_{2} \mathrm{O}=50: 1$ ) to afford the title compound $\mathbf{1 j}$ (16.3 mg, 45\% yield) as a colorless oil.

${ }^{1} \mathbf{H}$ NMR (300 MHz, $\mathrm{CDCl}_{3}$ ) $\delta: 7.98$ (d, $\left.J=8.3 \mathrm{~Hz}, 2 \mathrm{H}\right), 7.54$ (dd, $\left.J=8.6,1.4 \mathrm{~Hz}, 2 \mathrm{H}\right), 1.36$ (s, 9H) ppm. ${ }^{19} \mathbf{F}$

NMR (282 MHz, $\left.\mathrm{CDCl}_{3}\right) \delta: 17.14$ (s, 1F) ppm. MS (EI): m/z $180[\mathrm{M}]^{+}$. Spectroscopic data was agreement with the literature. ${ }^{3}$<smiles>CCCCCCCCCCCCCCCCCCC(=O)c1ccccc1</smiles>

\section{4-Butylbenzoyl fluoride (1k).}

From carboxylic acids: Following the general procedure B, using substrate $2 \mathbf{k}$ (0.2 mmol, 1.0 equiv), $\mathrm{PPh}_{3}$ (104.9 mg, $0.4 \mathrm{mmol}, 2.0$ equiv), TCCA (93.0 mg, $0.4 \mathrm{mmol}, 2.0$ equiv) and CsF (243.0 mg, $1.6 \mathrm{mmol}, 8.0$ equiv) in MeCN (1.0 mL), the reaction mixture was stirred at rt for 24 hours. The yield (95\%) was determined by ${ }^{19} \mathrm{~F}$ NMR of the crude reaction mixture. The crude mixture was purified by column chromatography ( $n$ Hexane) to afford the title compound $\mathbf{1 k}$ (18.2 $\mathrm{mg}, 51 \%$ yield) as a colorless oil.

From aldehydes: Following the general procedure C, using substrate 3k (0.2 mmol, 1.0 equiv), TCCA (93.0 mg, $0.4 \mathrm{mmol}$, 2.0 equiv) and CsF (243.0 mg, $1.6 \mathrm{mmol}, 8.0$ equiv) in MeCN (1.0 mL), the reaction mixture was stirred at rt for 24 hours. The yield (95\%) was determined by ${ }^{19} \mathrm{~F}$ NMR of the crude reaction mixture. The crude mixture was purified by column chromatography ( $n$-Hexane) to afford the title compound $\mathbf{1 k}$ (20.9 mg, $58 \%$ yield) as a colorless oil.

${ }^{1} \mathbf{H}$ NMR (300 MHz, $\left.\mathrm{CDCl}_{3}\right) \delta: 7.95(\mathrm{~d}, J=7.9 \mathrm{~Hz}, 2 \mathrm{H}), 7.33$ (d, $\left.J=7.8 \mathrm{~Hz}, 2 \mathrm{H}\right), 2.73-2.68$ (m, 2H), $1.65-$ 1.60 (m, 2H), 1.40 - 1.32 (m, 2H), 0.94 (t, $J=7.4$ Hz, 3H) ppm. ${ }^{19}$ F NMR (282 MHz, CDCl $) \delta: 16.94(\mathrm{~s}, 1 \mathrm{~F})$ ppm. MS (EI): m/z $180[\mathrm{M}]^{+}$. Spectroscopic data was agreement with the literature. ${ }^{4}$<smiles>O=C(F)c1ccc(C2CCCCC2)cc1</smiles>

\section{4-Cyclohexylbenzoyl fluoride (11).}

From carboxylic acids: Following the general procedure B, using substrate $2 \mathbf{l}$ (0.2 mmol, 1.0 equiv), $\mathrm{PPh}_{3}$ 
(104.9 mg, $0.4 \mathrm{mmol}, 2.0$ equiv), TCCA (93.0 mg, $0.4 \mathrm{mmol}, 2.0$ equiv) and CsF (243.0 mg, $1.6 \mathrm{mmol}, 8.0$ equiv) in MeCN (1.0 mL), the reaction mixture was stirred at rt for 24 hours. The yield (99\%) was determined by ${ }^{19} \mathrm{~F}$ NMR of the crude reaction mixture. The crude mixture was purified by column chromatography ( $n$ hexane: $\mathrm{EtOAc}=20: 1)$ to afford the title compound $\mathbf{1 l}(23.1 \mathrm{mg}, 56 \%$ yield $)$ as a colorless oil.

${ }^{1} \mathbf{H}$ NMR (300 MHz, $\left.\mathrm{CDCl}_{3}\right)$ ): 7.96 (d, $\left.J=6.1 \mathrm{~Hz}, 2 \mathrm{H}\right), 7.35$ (d, $\left.J=8.3 \mathrm{~Hz}, 2 \mathrm{H}\right), 2.61-2.59$ (m, 1H), 1.93 1.75 (m, 5H), 1.46 - 1.27 (m, 5H) ppm. ${ }^{19}$ F NMR (282 MHz, CDCl $)$ ) $: 16.95$ (s, 1F) ppm. MS (EI): m/z 206 $[\mathrm{M}]^{+}$. Spectroscopic data was agreement with the literature. ${ }^{3}$<smiles>Cc1cccc(C(=O)F)c1</smiles>

\section{3-Methylbenzoyl fluoride (1m).}

From carboxylic acids: Following the general procedure B, using substrate $\mathbf{2 m}$ (0.2 mmol, 1.0 equiv), $\mathrm{PPh}_{3}$ (104.9 mg, $0.4 \mathrm{mmol}, 2.0$ equiv), TCCA (93.0 mg, $0.4 \mathrm{mmol}, 2.0$ equiv) and CsF (243.0 mg, $1.6 \mathrm{mmol}, 8.0$ equiv) in MeCN (1.0 mL), the reaction mixture was stirred at rt for 24 hours. The yield (83\%) was determined by ${ }^{19} \mathrm{~F}$ NMR of the crude reaction mixture. The crude mixture was purified by column chromatography ( $n$ Pentane: $\left.\mathrm{Et}_{2} \mathrm{O}=20: 1\right)$ to afford the title compound $\mathbf{1 m}(18.5 \mathrm{mg}, 67 \%$ yield $)$ as a colorless oil.

${ }^{1} \mathbf{H}$ NMR (300 MHz, $\mathrm{CDCl}_{3}$ ) $\delta: 7.86-7.84$ (m, 2H), 7.51 (d, J = $\left.7.7 \mathrm{~Hz}, 1 \mathrm{H}\right), 7.44-7.38$ (m, 1H), 2.43 (s, 3H) ppm. ${ }^{19}$ F NMR (282 MHz, $\left.\mathrm{CDCl}_{3}\right) \delta: 17.76$ (s, 1F) ppm. MS (EI): m/z $138[\mathrm{M}]^{+}$. Spectroscopic data was agreement with the literature. ${ }^{1}$<smiles>O=C(F)c1ccccc1F</smiles>

\section{2-Fluorobenzoyl fluoride (1n).}

From carboxylic acids: Following the general procedure A, using substrate 2n (0.2 mmol, 1.0 equiv), TCCA (93.0 mg, $0.4 \mathrm{mmol}, 2.0$ equiv) and CsF (243.0 mg, $1.6 \mathrm{mmol}, 8.0$ equiv) in MeCN (1.0 mL), the reaction mixture was stirred at rt for 24 hours. The yield (89\%) was determined by ${ }^{19} \mathrm{~F}$ NMR of the crude reaction mixture. The crude mixture was purified by column chromatography ( $n$-Pentane: $\mathrm{Et}_{2} \mathrm{O}=20: 1$ ) to afford the title compound 1n (19.9 mg, 70\% yield) as a colorless oil.

${ }^{1} \mathbf{H}$ NMR (300 MHz, $\mathrm{CDCl}_{3}$ ) $\delta: 7.99$ (t, $\left.J=7.5 \mathrm{~Hz}, 1 \mathrm{H}\right), 7.75-7.67$ (m, 1H), $7.35-7.21$ (m, 2H) ppm. ${ }^{19} \mathbf{F}$ NMR (282 MHz, $\left.\mathrm{CDCl}_{3}\right) \delta: 31.12(\mathrm{~d}, J=40.7 \mathrm{~Hz}, 1 \mathrm{~F}),-106.58--106.83$ (m, 1F) ppm. MS (EI): m/z 138 $[\mathrm{M}]^{+}$. Spectroscopic data was agreement with the literature. ${ }^{5}$<smiles>O=C(F)c1ccccc1Br</smiles>

\section{2-Bromobenzoyl fluoride (10).}


From carboxylic acids: Following the general procedure A, using substrate 20 (0.2 mmol, 1.0 equiv), TCCA (93.0 mg, $0.4 \mathrm{mmol}, 2.0$ equiv) and CsF (243.0 mg, $1.6 \mathrm{mmol}, 8.0$ equiv) in MeCN (1.0 mL), the reaction mixture was stirred at rt for 24 hours. The yield (94\%) was determined by ${ }^{19} \mathrm{~F}$ NMR of the crude reaction mixture. The crude mixture was purified by column chromatography ( $n$-Hexane: EtOAc $=20: 1)$ to afford the title compound 10 (29.3 mg, 72\% yield) as a white solid.

From aldehydes: Following the general procedure $\mathbf{C}$, using substrate $3 \mathbf{o}$ (0.2 mmol, 1.0 equiv), TCCA (93.0 mg, $0.4 \mathrm{mmol}$, 2.0 equiv) and CsF (243.0 mg, $1.6 \mathrm{mmol}, 8.0$ equiv) in MeCN (1.0 mL), the reaction mixture was stirred at rt for 24 hours. The yield (84\%) was determined by ${ }^{19} \mathrm{~F}$ NMR of the crude reaction mixture. The crude mixture was purified by column chromatography ( $n$-Hexane: EtOAc $=20: 1)$ to afford the title compound 10 (20.3 mg, 50\% yield) as a white solid.

From alcohols: Following the general procedure D, using substrate 40 (0.2 mmol, 1.0 equiv), TCCA (139.4 mg, $0.6 \mathrm{mmol}$, 3.0 equiv) and CsF (303.8 mg, $2.0 \mathrm{mmol}, 10.0$ equiv) in MeCN (1.0 mL), the reaction mixture was stirred at rt for 24 hours. The yield (70\%) was determined by ${ }^{19} \mathrm{~F}$ NMR of the crude reaction mixture. The crude mixture was purified by column chromatography ( $n$-Hexane: EtOAc $=20: 1)$ to afford the title compound 10 (21.6 mg, 53\% yield) as a white solid.

m.p.: 28.9 - $29.8{ }^{\circ} \mathrm{C} .{ }^{1} \mathbf{H}$ NMR (300 MHz, $\mathrm{CDCl}_{3}$ ) $\delta: 8.05$ - 8.01 (m, 1H), 7.81 - 7.77 (m, 1H), 7.53 - 7.45 (m, 2H) ppm. ${ }^{19}$ F NMR (282 MHz, $\left.\mathrm{CDCl}_{3}\right) \delta: 30.97$ (s, 1F) ppm. ${ }^{13} \mathbf{C}$ NMR (176 MHz, CDCl 3 ) $\delta: 154.8(\mathrm{~d}, J$ = $344.7 \mathrm{~Hz}$ ), 135.5 (d, $J=3.5 \mathrm{~Hz}), 135.3,133.7$ (d, $J=2.2 \mathrm{~Hz}), 127.6,125.4$ (d, $J=59.6 \mathrm{~Hz}), 124.8$ (d, $J=$ $4.8 \mathrm{~Hz}$ ) ppm. IR (KBr): 1820, 1588, 1435, 1231, 1000, 738, 677, $635 \mathrm{~cm}^{-1}$. HRMS (EI) m/z: [M] Calcd for $\mathrm{C}_{7} \mathrm{H}_{4} \mathrm{BrFO}^{+}$201.9430; Found 201.9437.<smiles>O=C(F)c1ccccc1-c1ccccc1</smiles>

\section{[1,1'-Biphenyl]-2-carbonyl fluoride (1p).}

From carboxylic acids: Following the general procedure B, using substrate 2p (0.2 mmol, 1.0 equiv), $\mathrm{PPh}_{3}$ (104.9 mg, $0.4 \mathrm{mmol}, 2.0$ equiv), TCCA (93.0 mg, $0.4 \mathrm{mmol}, 2.0$ equiv) and CsF (243.0 mg, $1.6 \mathrm{mmol}, 8.0$ equiv) in MeCN (1.0 mL), the reaction mixture was stirred at rt for 24 hours. The yield (94\%) was determined by ${ }^{19} \mathrm{~F}$ NMR of the crude reaction mixture. The crude mixture was purified by column chromatography ( $n$ Hexane: EtOAc $=50: 1)$ to afford the title compound 1p (32.5 mg, 81\% yield) as a white solid.

From aldehydes: Following the general procedure C, using substrate $3 \mathbf{p}$ (0.2 mmol, 1.0 equiv), TCCA (93.0 mg, $0.4 \mathrm{mmol}$, 2.0 equiv) and CsF (243.0 mg, $1.6 \mathrm{mmol}, 8.0$ equiv) in MeCN (1.0 mL), the reaction mixture was stirred at rt for 24 hours. The yield (69\%) was determined by ${ }^{19} \mathrm{~F}$ NMR of the crude reaction mixture. The crude mixture was purified by column chromatography ( $n$-Hexane: EtOAc $=50: 1)$ to afford the title compound 1p (17.2 mg, 43\% yield) as a white solid.

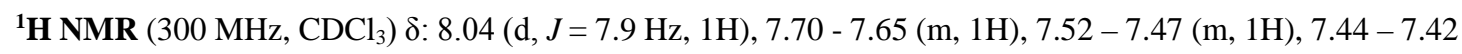
(m, 4H), $7.34-7.31$ (m, 2H) ppm. ${ }^{19}$ F NMR (282 MHz, CDCl $)$ ) $: 34.42$ (s, 1F) ppm. MS (EI): m/z 200 [M] . Spectroscopic data was agreement with the literature. ${ }^{2}$ 
<smiles>O=C(F)c1ccc2ccccc2c1</smiles>

\section{2-Naphthoyl fluoride (1q).}

From carboxylic acids: Following the general procedure B, using substrate $\mathbf{2 q}\left(0.2 \mathrm{mmol}, 1.0\right.$ equiv), $\mathrm{PPh}_{3}$ (104.9 mg, 0.4 mmol, 2.0 equiv), TCCA (93.0 mg, 0.4 mmol, 2.0 equiv) and CsF (243.0 mg, 1.6 mmol, 8.0 equiv) in MeCN (1.0 mL), the reaction mixture was stirred at rt for 24 hours. The yield (67\%) was determined by ${ }^{19} \mathrm{~F}$ NMR of the crude reaction mixture. The crude mixture was purified by column chromatography ( $n$ Hexane: EtOAc = 20:1) to afford the title compound 1q (19.2 mg, 55\% yield) as a white solid.

${ }^{1} \mathbf{H}$ NMR (300 MHz, $\left.\mathrm{CDCl}_{3}\right) \delta: 8.64(\mathrm{~s}, 1 \mathrm{H}), 8.02-7.91$ (m, 4H), $7.71-7.59$ (m, 2H) ppm. ${ }^{19}$ F NMR (282 $\left.\mathrm{MHz}, \mathrm{CDCl}_{3}\right) \delta: 17.53$ (s, 1F) ppm. MS (EI): m/z $174[\mathrm{M}]^{+}$. Spectroscopic data was agreement with the literature. ${ }^{1}$<smiles>O=C(F)c1cccc2ccccc12</smiles>

\section{1-Naphthoyl fluoride (1r).}

From carboxylic acids: Following the general procedure B, using substrate $2 \mathbf{r}$ (0.2 mmol, 1.0 equiv), $\mathrm{PPh}_{3}$ (104.9 mg, 0.4 mmol, 2.0 equiv), TCCA (93.0 mg, 0.4 mmol, 2.0 equiv) and CsF (243.0 mg, 1.6 mmol, 8.0 equiv) in MeCN (1.0 mL), the reaction mixture was stirred at rt for 24 hours. The yield (61\%) was determined by ${ }^{19} \mathrm{~F}$ NMR of the crude reaction mixture. The crude mixture was purified by column chromatography ( $n$ Hexane) to afford the title compound $\mathbf{1 r}$ (15.3 $\mathrm{mg}, 44 \%$ yield) as a white solid.

${ }^{1} \mathrm{H}$ NMR (300 MHz, $\left.\mathrm{CDCl}_{3}\right) \delta: 9.02(\mathrm{~d}, J=8.7 \mathrm{~Hz}, 1 \mathrm{H}), 8.36$ (d, $\left.J=7.3 \mathrm{~Hz}, 1 \mathrm{H}\right), 8.19$ (d, $\left.J=8.2 \mathrm{~Hz}, 1 \mathrm{H}\right)$,

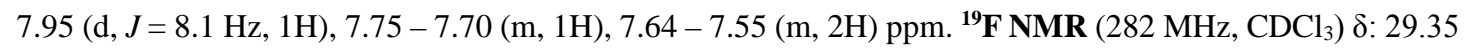
(s, 1F) ppm. MS (EI): m/z $174[\mathrm{M}]^{+}$. Spectroscopic data was agreement with the literature. ${ }^{1}$<smiles>O=C(F)c1cc(Cl)cc(Cl)c1</smiles>

\section{3,5-Dichlorobenzoyl fluoride (1s).}

From carboxylic acids: Following the general procedure A, using substrate $2 \mathbf{s}$ ( $0.2 \mathrm{mmol}, 1.0$ equiv), TCCA (93.0 mg, $0.4 \mathrm{mmol}, 2.0$ equiv) and CsF (243.0 mg, $1.6 \mathrm{mmol}$, 8.0 equiv) in MeCN (1.0 mL), the reaction mixture was stirred at rt for 24 hours. The yield (>99\%) was determined by ${ }^{19} \mathrm{~F}$ NMR of the crude reaction mixture. The crude mixture was washed with Hexane/DCM $(9: 1,5 \mathrm{~mL} \times 2)$ to afford the title compound $1 \mathrm{~s}$ (26.7 $\mathrm{mg}, 69 \%$ yield) as a white solid.

From aldehydes: Following the general procedure $\mathbf{C}$, using substrate $3 \mathrm{~s}$ ( $0.2 \mathrm{mmol}, 1.0$ equiv), TCCA (93.0 
mg, $0.4 \mathrm{mmol}$, 2.0 equiv) and CsF (243.0 mg, $1.6 \mathrm{mmol}$, 8.0 equiv) in MeCN (1.0 mL), the reaction mixture was stirred at rt for 24 hours. The yield (99\%) was determined by ${ }^{19} \mathrm{~F}$ NMR of the crude reaction mixture. The crude mixture was washed with Hexane/DCM $(9: 1,5 \mathrm{~mL} \times 2)$ to afford the title compound 1s $(24.7 \mathrm{mg}, 66 \%$ yield) as a white solid.

${ }^{1} \mathbf{H}$ NMR (300 MHz, $\left.\mathrm{CDCl}_{3}\right) \delta: 7.92$ (s, 2H), $7.70-7.69$ (m, 1H) ppm. ${ }^{19} \mathbf{F}$ NMR (282 MHz, CDCl $)$ $\delta: 19.46$ (s, 1F) ppm. MS (EI): m/z $192[\mathrm{M}]^{+}$. Spectroscopic data was agreement with the literature. ${ }^{6}$

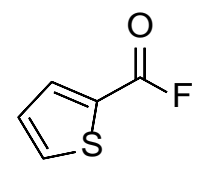

\section{Thiophene-2-carbonyl fluoride (1t).}

From carboxylic acids: Following the general procedure B, using substrate 2t (0.2 mmol, 1.0 equiv), $\mathrm{PPh}_{3}$ (104.9 mg, 0.4 mmol, 2.0 equiv), TCCA (93.0 mg, 0.4 mmol, 2.0 equiv) and CsF (243.0 mg, $1.6 \mathrm{mmol}, 8.0$ equiv) in MeCN $(1.0 \mathrm{~mL})$, the reaction mixture was stirred at rt for 24 hours. The yield (70\%) was determined by ${ }^{19} \mathrm{~F}$ NMR of the crude reaction mixture. The crude mixture was purified by column chromatography ( $n$ Pentane: $\left.\mathrm{Et}_{2} \mathrm{O}=20: 1\right)$ to afford the title compound $\mathbf{1 t}(7.8 \mathrm{mg}, 30 \%$ yield) as a colorless oil.

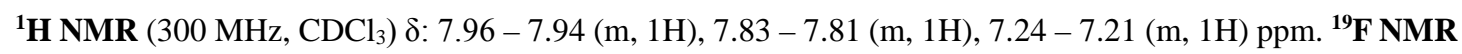
$\left(282 \mathrm{MHz}, \mathrm{CDCl}_{3}\right) \delta: 23.82(\mathrm{~s}, 1 \mathrm{~F}) \mathrm{ppm} . \mathrm{MS}(\mathrm{EI}): \mathrm{m} / \mathrm{z} 130[\mathrm{M}]^{+}$. Spectroscopic data was agreement with the literature. $^{1}$

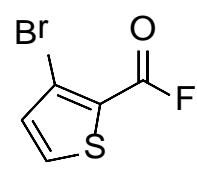

\section{3-Bromothiophene-2-carbonyl fluoride (1u).}

From carboxylic acids: Following the general procedure B, using substrate $2 \mathbf{u}\left(0.2 \mathrm{mmol}, 1.0\right.$ equiv), $\mathrm{PPh}_{3}$ (104.9 mg, 0.4 mmol, 2.0 equiv), TCCA (93.0 mg, 0.4 mmol, 2.0 equiv) and CsF (243.0 mg, $1.6 \mathrm{mmol}, 8.0$ equiv) in MeCN (1.0 mL), the reaction mixture was stirred at rt for 24 hours. The yield (81\%) was determined by ${ }^{19} \mathrm{~F}$ NMR of the crude reaction mixture. The crude mixture was purified by column chromatography ( $n$ Hexane: EtOAc = 20:1) to afford the title compound 1u (24.2 mg, 58\% yield) as a white solid.

${ }^{1} \mathbf{H}$ NMR (300 MHz, $\left.\mathrm{CDCl}_{3}\right) \delta: 7.71(\mathrm{~d}, J=5.2 \mathrm{~Hz}, 1 \mathrm{H}), 7.23(\mathrm{dd}, J=5.1,3.0 \mathrm{~Hz}, 1 \mathrm{H}) \mathrm{ppm} .{ }^{19} \mathbf{F}$ NMR $(282$ $\mathrm{MHz}_{\mathrm{CDCl}}$ ) $\delta: 32.61$ (s, 1F) ppm. MS (EI): m/z $208[\mathrm{M}]^{+}$. Spectroscopic data was agreement with the literature. $^{2}$<smiles>CC(C)(C)CC(=O)C(C)(C)C</smiles>

\section{Dodecanoyl fluoride (1v).}

From carboxylic acids: Following the general procedure $\mathbf{B}$, using substrate $\mathbf{2 v}$ (0.2 mmol, 1.0 equiv), $\mathrm{PPh}_{3}$ (104.9 mg, $0.4 \mathrm{mmol}, 2.0$ equiv), TCCA (93.0 mg, $0.4 \mathrm{mmol}, 2.0$ equiv) and CsF (243.0 mg, $1.6 \mathrm{mmol}, 8.0$ 
equiv) in MeCN (1.0 mL), the reaction mixture was stirred at rt for 24 hours. The yield (80\%) was determined by ${ }^{19} \mathrm{~F}$ NMR of the crude reaction mixture. The crude mixture was purified by column chromatography ( $n$ Pentane: $\left.\mathrm{Et}_{2} \mathrm{O}=50: 1\right)$ to afford the title compound $\mathbf{1 v}(29.2 \mathrm{mg}, 72 \%$ yield) as a colorless oil.

From aldehydes: Following the general procedure $\mathbf{C}$, using substrate $3 \mathbf{v}$ (0.2 mmol, 1.0 equiv), TCCA (93.0 mg, $0.4 \mathrm{mmol}, 2.0$ equiv) and CsF (243.0 mg, $1.6 \mathrm{mmol}$, 8.0 equiv) in MeCN (1.0 mL), the reaction mixture was stirred at rt for 24 hours. The yield (33\%) was determined by ${ }^{19} \mathrm{~F}$ NMR of the crude reaction mixture. The crude mixture was purified by column chromatography ( $n$-Pentane: $\mathrm{Et}_{2} \mathrm{O}=50: 1$ ) to afford the title compound $1 \mathbf{v}$ (6.5 mg, 16\% yield) as a colorless oil.

${ }^{1} \mathbf{H}$ NMR (300 MHz, $\left.\mathrm{CDCl}_{3}\right) \delta: 2.51(\mathrm{t}, J=7.4 \mathrm{~Hz}, 2 \mathrm{H}), 1.70-1.63$ (m, 2H), $1.39-1.27$ (m, $\left.16 \mathrm{H}\right), 0.90$ 0.86 (m, 3H) ppm. ${ }^{19}$ F NMR (282 MHz, $\left.\mathrm{CDCl}_{3}\right) \delta: 44.94$ (s, 1F) ppm. MS (EI): m/z 202 [M] $]^{+}$. Spectroscopic data was agreement with the literature. ${ }^{7}$

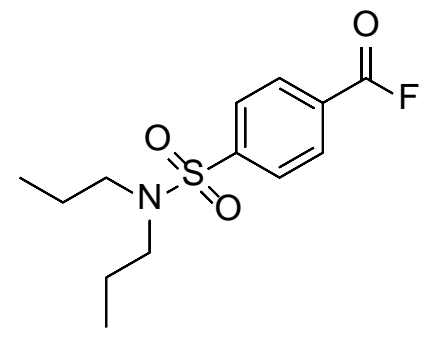

\section{4-(N,N-Dipropylsulfamoyl)benzoyl fluoride (1w).}

From carboxylic acids: Following the general procedure B, using substrate 2w (0.2 mmol, 1.0 equiv), $\mathrm{PPh}_{3}$ (104.9 mg, $0.4 \mathrm{mmol}, 2.0$ equiv), TCCA (93.0 mg, $0.4 \mathrm{mmol}, 2.0$ equiv) and CsF (243.0 mg, $1.6 \mathrm{mmol}, 8.0$ equiv) in MeCN (1.0 mL), the reaction mixture was stirred at rt for 24 hours. The yield (64\%) was determined by ${ }^{19} \mathrm{~F}$ NMR of the crude reaction mixture. The crude mixture was washed with Hexane/DCM $(9: 1,5 \mathrm{~mL} \times 2)$ to afford the title compound $\mathbf{1 w}(29.3 \mathrm{mg}, 51 \%$ yield) as a white solid.

From aldehydes: Following the general procedure C, using substrate 3w (0.2 mmol, 1.0 equiv), TCCA (93.0 mg, $0.4 \mathrm{mmol}$, 2.0 equiv) and CsF (243.0 mg, $1.6 \mathrm{mmol}$, 8.0 equiv) in MeCN (1.0 mL), the reaction mixture was stirred at rt for 24 hours. The yield (67\%) was determined by ${ }^{19} \mathrm{~F}$ NMR of the crude reaction mixture. The crude mixture was washed with Hexane/DCM (9:1, $5 \mathrm{~mL} \times 2$ ) to afford the title compound $1 \mathbf{w}$ (27.3 mg, 48\% yield) as a white solid.

${ }^{1} \mathbf{H}$ NMR (300 MHz, $\mathrm{CDCl}_{3}$ ) $\delta: 8.20$ - 8.17 (m, 2H), 7.97 (d, J = 7.9 Hz, 2H), 3.19 - 3.07 (m, 4H), 1.62 - 1.50 (m, 4H), 0.88 (t, $J=7.4 \mathrm{~Hz}, 6 \mathrm{H})$ ppm. ${ }^{19}$ F NMR (282 MHz, CDCl $) \delta: 19.72$ (s, 1F) ppm. MS (EI): m/z 287 $[\mathrm{M}]^{+}$. Spectroscopic data was agreement with the literature. ${ }^{4}$<smiles>C[C@]12CC[C@@H]3c4ccc(C(=O)F)cc4CC[C@H]3[C@H]1CCC2=O</smiles>

(8R,9S,13S,14S)-13-Methyl-17-oxo-7,8,9,11,12,13,14,15,16,17-decahydro-6H- 


\section{cyclopenta[a]phenanthrene-3-carbonyl fluoride (1x).}

From carboxylic acids: Following the general procedure $\mathbf{B}$, using substrate 2x (0.2 mmol, 1.0 equiv), $\mathrm{PPh}_{3}$ (104.9 mg, $0.4 \mathrm{mmol}, 2.0$ equiv), TCCA (93.0 mg, $0.4 \mathrm{mmol}, 2.0$ equiv) and CsF (243.0 mg, $1.6 \mathrm{mmol}, 8.0$ equiv) in MeCN (1.0 mL), the reaction mixture was stirred at rt for 24 hours. The yield (80\%) was determined by ${ }^{19} \mathrm{~F}$ NMR of the crude reaction mixture. The crude mixture was purified by column chromatography ( $n$ Hexane: EtOAc = 3:1) to afford the title compound $\mathbf{1 x}(33.0 \mathrm{mg}$, 55\% yield) as a white solid.

${ }^{1} \mathbf{H}$ NMR (300 MHz, $\left.\mathrm{CDCl}_{3}\right) \delta: 7.80(\mathrm{~d}, J=11.5 \mathrm{~Hz}, 2 \mathrm{H}), 7.44$ (d, $\left.J=8.0 \mathrm{~Hz}, 1 \mathrm{H}\right), 3.01$ - 2.95 (m, 2H), 2.58 - 2.33 (m, 3H), 2.20 - 1.99 (m, 4H), $1.70-1.46$ (m, 6H), 0.93 (s, 3H) ppm. ${ }^{19}$ F NMR (282 MHz, $\left.\mathrm{CDCl}_{3}\right) \delta$ : 17.29 (s, 1F) ppm. MS (EI): m/z $300[\mathrm{M}]^{+}$. Spectroscopic data was agreement with the literature. ${ }^{1}$<smiles>CCc1ccc(C(=O)F)cc1</smiles>

\section{4-Ethylbenzoyl fluoride (1y).}

From aldehydes: Following the general procedure C, using substrate $3 \mathbf{y}$ (0.2 mmol, 1.0 equiv), TCCA (93.0 mg, $0.4 \mathrm{mmol}, 2.0$ equiv) and CsF (243.0 mg, $1.6 \mathrm{mmol}$, 8.0 equiv) in MeCN (1.0 mL), the reaction mixture was stirred at rt for 24 hours. The yield (92\%) was determined by ${ }^{19} \mathrm{~F}$ NMR of the crude reaction mixture. The crude mixture was purified by column chromatography ( $n$-Hexane: $\mathrm{Et}_{2} \mathrm{O}=20: 1$ ) to afford the title compound $1 \mathbf{y}$ (21.6 mg, 70\% yield) as a colorless oil.

${ }^{1} \mathbf{H}$ NMR (300 MHz, $\left.\mathrm{CDCl}_{3}\right) \delta: 7.96(\mathrm{~d}, J=8.4 \mathrm{~Hz}, 2 \mathrm{H}), 7.35$ (d, $\left.J=8.2 \mathrm{~Hz}, 2 \mathrm{H}\right), 2.75$ (q, $\left.J=7.6 \mathrm{~Hz}, 2 \mathrm{H}\right)$, 1.27 (t, $J=7.6 \mathrm{~Hz}, 3 \mathrm{H})$ ppm. ${ }^{19} \mathbf{F}$ NMR (282 MHz, $\left.\mathrm{CDCl}_{3}\right) \delta: 16.98$ (s, 1F) ppm. MS (EI): m/z 152 [M] . Spectroscopic data was agreement with the literature. ${ }^{3}$<smiles>O=C(F)c1ccc(OC(F)(F)F)cc1</smiles>

\section{4-(Trifluoromethoxy)benzoyl fluoride (1z).}

From aldehydes: Following the general procedure $\mathbf{C}$, using substrate $\mathbf{3 z}$ ( $0.2 \mathrm{mmol}$, 1.0 equiv), TCCA (93.0 mg, $0.4 \mathrm{mmol}, 2.0$ equiv) and CsF (243.0 mg, $1.6 \mathrm{mmol}$, 8.0 equiv) in MeCN (1.0 mL), the reaction mixture was stirred at rt for 24 hours. The yield (97\%) was determined by ${ }^{19} \mathrm{~F}$ NMR of the crude reaction mixture. The crude mixture was purified by column chromatography ( $n$-Pentane: $\mathrm{Et}_{2} \mathrm{O}=50: 1$ ) to afford the title compound $1 z$ (27.9 mg, 67\% yield) as a colorless oil.

From alcohols: Following the general procedure D, using substrate $\mathbf{4 z}$ (0.2 mmol, 1.0 equiv), TCCA (139.4 mg, $0.6 \mathrm{mmol}$, 3.0 equiv) and CsF (303.8 mg, $2.0 \mathrm{mmol}, 10.0$ equiv) in MeCN (1.0 mL), the reaction mixture was stirred at rt for 24 hours. The yield (41\%) was determined by ${ }^{19} \mathrm{~F}$ NMR of the crude reaction mixture. The crude mixture was purified by column chromatography ( $n$-Pentane: $\mathrm{Et}_{2} \mathrm{O}=50: 1$ ) to afford the title compound 
$\mathbf{1 z}$ (9.6 mg, 23\% yield) as a colorless oil.

${ }^{1} \mathbf{H}$ NMR (300 MHz, $\left.\mathrm{CDCl}_{3}\right) \delta: 8.13-8.10$ (m, 2H), 7.36 (d, $\left.J=8.4 \mathrm{~Hz}, 2 \mathrm{H}\right)$ ppm. ${ }^{19}$ F NMR (282 MHz, $\left.\mathrm{CDCl}_{3}\right) \delta: 18.18(\mathrm{~s}, 1 \mathrm{~F}),-58.11(\mathrm{~s}, 3 \mathrm{~F}) \mathrm{ppm} . \mathrm{MS}(\mathrm{EI}): \mathrm{m} / \mathrm{z} 208[\mathrm{M}]^{+}$. Spectroscopic data was agreement with the literature. ${ }^{8}$<smiles>N#Cc1ccc(C(=O)F)cc1</smiles>

\section{4-Cyanobenzoyl fluoride (1za).}

From aldehydes: Following the general procedure C, using substrate 3za (0.2 mmol, 1.0 equiv), TCCA (93.0 mg, $0.4 \mathrm{mmol}$, 2.0 equiv) and CsF (243.0 mg, $1.6 \mathrm{mmol}$, 8.0 equiv) in MeCN (1.0 mL), the reaction mixture was stirred at rt for 24 hours. The yield (>99\%) was determined by ${ }^{19} \mathrm{~F}$ NMR of the crude reaction mixture. The crude mixture was washed with Hexane/DCM $(9: 1,5 \mathrm{~mL} \times 2)$ to afford the title compound 1za (27.3 mg, $92 \%$ yield) as a white solid.

${ }^{1} \mathbf{H}$ NMR $\left(300 \mathrm{MHz}, \mathrm{CDCl}_{3}\right) \delta: 8.18(\mathrm{~d}, J=8.2 \mathrm{~Hz}, 2 \mathrm{H}), 7.86(\mathrm{~d}, J=7.8 \mathrm{~Hz}, 2 \mathrm{H}) \mathrm{ppm} .{ }^{19} \mathbf{F}$ NMR $(282 \mathrm{MHz}$, $\left.\mathrm{CDCl}_{3}\right) \delta: 19.72$ (s, 1F) ppm. MS (EI): m/z $149[\mathrm{M}]^{+}$. Spectroscopic data was agreement with the literature. ${ }^{2}$<smiles>O=C(F)c1cccc(Br)c1</smiles>

3-Bromobenzoyl fluoride (1zb).

From aldehydes: Following the general procedure C, using substrate $3 \mathbf{z b}$ (0.2 mmol, 1.0 equiv), TCCA (93.0 mg, $0.4 \mathrm{mmol}$, 2.0 equiv) and CsF (243.0 mg, $1.6 \mathrm{mmol}$, 8.0 equiv) in MeCN (1.0 mL), the reaction mixture was stirred at rt for 24 hours. The yield (83\%) was determined by ${ }^{19} \mathrm{~F}$ NMR of the crude reaction mixture. The crude mixture was purified by column chromatography ( $n$-Hexane: EtOAc $=20: 1)$ to afford the title compound 1zb (20.3 mg, 50\% yield) as a white solid.

From alcohols: Following the general procedure D, using substrate $\mathbf{4 z b}$ (0.2 mmol, 1.0 equiv), TCCA (139.4 mg, $0.6 \mathrm{mmol}, 3.0$ equiv) and CsF (303.8 mg, $2.0 \mathrm{mmol}, 10.0$ equiv) in MeCN (1.0 mL), the reaction mixture was stirred at rt for 24 hours. The yield (87\%) was determined by ${ }^{19} \mathrm{~F}$ NMR of the crude reaction mixture. The crude mixture was purified by column chromatography $(n$-Hexane: EtOAc $=20: 1)$ to afford the title compound 1zb (28.5 mg, 70\% yield) as a white solid.

${ }^{1} \mathbf{H}$ NMR (300 MHz, $\left.\mathrm{CDCl}_{3}\right) \delta: 8.19$ (t, $\left.J=1.9 \mathrm{~Hz}, 1 \mathrm{H}\right), 7.99$ (d, $\left.J=7.9 \mathrm{~Hz}, 1 \mathrm{H}\right), 7.85-7.82$ (m, 1H), 7.43 (t, $J=7.6 \mathrm{~Hz}, 1 \mathrm{H})$ ppm. ${ }^{19}$ F NMR (282 MHz, CDCl $) \delta: 18.56$ (s, 1F) ppm. MS (EI): m/z 202 [M] $]^{+}$. Spectroscopic data was agreement with the literature. ${ }^{8}$ 
<smiles>O=C(F)c1ccccc1[N+](=O)[O-]</smiles>

\section{2-Nitrobenzoyl fluoride (1zc).}

From aldehydes: Following the general procedure $\mathbf{C}$, using substrate $3 z c(0.2 \mathrm{mmol}$, 1.0 equiv), TCCA (93.0 mg, $0.4 \mathrm{mmol}$, 2.0 equiv) and CsF (243.0 mg, $1.6 \mathrm{mmol}$, 8.0 equiv) in $\mathrm{MeCN}(1.0 \mathrm{~mL})$, the reaction mixture was stirred at rt for 24 hours. The yield (87\%) was determined by ${ }^{19} \mathrm{~F}$ NMR of the crude reaction mixture. The crude mixture was washed with Hexane/DCM $(9: 1,5 \mathrm{~mL} \times 2)$ to afford the title compound $1 \mathbf{z c}$ ( $27.4 \mathrm{mg}, 81 \%$ yield) as a white solid.

${ }^{1} \mathbf{H}$ NMR (300 MHz, CDCl $)$ ) $8: 8.07$ - 8.04 (m, 1H), 7.90 - 7.86 (m, 1H), $7.82-7.79$ (m, 2H). ppm. ${ }^{19} \mathbf{F}$ NMR $\left(282 \mathrm{MHz}, \mathrm{CDCl}_{3}\right) \delta: 39.63$ (s, 1F) ppm. MS (EI): m/z $169[\mathrm{M}]^{+}$. Spectroscopic data was agreement with the literature. ${ }^{9}$<smiles>O=C(F)c1ccc2ccccc2c1Br</smiles>

\section{1-Bromo-2-naphthoyl fluoride (1zd).}

From aldehydes: Following the general procedure $\mathbf{C}$, using substrate $\mathbf{3 z d}$ ( $0.2 \mathrm{mmol}, 1.0$ equiv), TCCA (93.0 mg, $0.4 \mathrm{mmol}$, 2.0 equiv) and CsF (243.0 mg, $1.6 \mathrm{mmol}$, 8.0 equiv) in MeCN (1.0 mL), the reaction mixture was stirred at rt for 24 hours. The yield (91\%) was determined by ${ }^{19} \mathrm{~F}$ NMR of the crude reaction mixture. The crude mixture was washed with Hexane/DCM (9:1, $5 \mathrm{~mL} \times 2$ ) to afford the title compound 1zd (35.4 mg, 70\% yield) as a white solid.

m.p.: 89.6 - $90.1^{\circ}{ }^{\circ} \mathrm{C} .{ }^{1} \mathbf{H}$ NMR (300 MHz, $\mathrm{CDCl}_{3}$ ) $\delta: 8.57$ - 8.53 (m, 1H), 7.92 - 7.87 (m, 3H), 7.72 - 7.69 (m, 2H) ppm. ${ }^{19} \mathbf{F}$ NMR (282 MHz, $\left.\mathrm{CDCl}_{3}\right) \delta: 36.19$ (s, 1F) ppm. ${ }^{13} \mathbf{C}$ NMR (126 MHz, $\left.\mathrm{CDCl}_{3}\right) \delta: 155.8(\mathrm{~d}$, C-F, ${ }^{1} J_{\mathrm{C}-\mathrm{F}}=345.1 \mathrm{~Hz}$ ), 136.4, 132.7 (d, C-F, ${ }^{4} \mathrm{~J}_{\mathrm{C}-\mathrm{F}}=3.3 \mathrm{~Hz}$ ), 129.8, 129.4, 128.7, 128.3 (d, C-F, ${ }^{3} \mathrm{~J}_{\mathrm{C}-\mathrm{F}}=7.5$ $\mathrm{Hz}$ ), $128.0\left(\mathrm{~d}, \mathrm{C}-\mathrm{F},{ }^{3} J_{\mathrm{C}-\mathrm{F}}=5.0 \mathrm{~Hz}\right), 126.7\left(\mathrm{~d}, \mathrm{C}-\mathrm{F},{ }^{4} J_{\mathrm{C}-\mathrm{F}}=2.3 \mathrm{~Hz}\right), 123.8\left(\mathrm{~d}, \mathrm{C}-\mathrm{F},{ }^{2} J_{\mathrm{C}-\mathrm{F}}=61.3 \mathrm{~Hz}\right) \mathrm{ppm} . \mathbf{I R}$ (KBr): 2928, 1820, 1595, 1455, 1222, 1063, 954, 759, $539 \mathrm{~cm}^{-1}$. HRMS (EI) m/z: [M] ${ }^{+}$Calcd for $\mathrm{C}_{11} \mathrm{H}_{6} \mathrm{OFBr}^{+}$ 251.9586; Found 251.9589.<smiles>O=C(F)c1cc(Br)cc(Br)c1</smiles>

\section{3,5-Dibromobenzoyl fluoride (1ze).}

From aldehydes: Following the general procedure $\mathbf{C}$, using substrate $3 z e$ ( $0.2 \mathrm{mmol}, 1.0$ equiv), TCCA (93.0 mg, $0.4 \mathrm{mmol}$, 2.0 equiv) and CsF (243.0 mg, $1.6 \mathrm{mmol}$, 8.0 equiv) in $\mathrm{MeCN}(1.0 \mathrm{~mL})$, the reaction mixture was stirred at rt for 24 hours. The yield (89\%) was determined by ${ }^{19} \mathrm{~F}$ NMR of the crude reaction mixture. The crude mixture was purified by column chromatography ( $n$-Hexane: EtOAc $=20: 1)$ to afford the title compound 
1ze (31.0 mg, 55\% yield) as a white solid.

m.p.: 62.1 - $63.1^{\circ} \mathrm{C} .{ }^{1} \mathbf{H}$ NMR (300 MHz, $\left.\mathrm{CDCl}_{3}\right) \delta: 8.13-8.11(\mathrm{~m}, 2 \mathrm{H}), 8.01-7.99(\mathrm{~m}, 1 \mathrm{H})$ ppm. ${ }^{19}$ F NMR $\left(282 \mathrm{MHz}, \mathrm{CDCl}_{3}\right) \delta: 19.34$ (s, 1F) ppm. ${ }^{13} \mathrm{C} \mathrm{NMR}\left(126 \mathrm{MHz}, \mathrm{CDCl}_{3}\right) \delta: 154.8\left(\mathrm{~d}, \mathrm{C}-\mathrm{F},{ }^{1} J_{\mathrm{C}-\mathrm{F}}=345.9 \mathrm{~Hz}\right)$, 140.7, 132.8 (d, C-F, ${ }^{3} J_{\mathrm{C}-\mathrm{F}}=3.6 \mathrm{~Hz}$ ), 128.0 (d, C-F, $\left.{ }^{2} J_{\mathrm{C}-\mathrm{F}}=63.8 \mathrm{~Hz}\right), 123.6$ (d, C-F, $\left.{ }^{4} J_{\mathrm{C}-\mathrm{F}}=1.5 \mathrm{~Hz}\right) \mathrm{ppm}$. IR (KBr): 3072, 1811, 1557, 1419, 1240, 1055, 886, 827, 671, $658 \mathrm{~cm}^{-1}$. HRMS (EI) m/z: [M] Calcd for $\mathrm{C}_{7} \mathrm{H}_{3} \mathrm{OFBr}_{2}{ }^{+}$279.8535; Found 279.8535.<smiles>O=C(F)c1ccc(Cl)c(Cl)c1</smiles>

\section{3,4-Dichlorobenzoyl fluoride (1zf).}

From aldehydes: Following the general procedure C, using substrate 3zf (0.2 mmol, 1.0 equiv), TCCA (93.0 mg, $0.4 \mathrm{mmol}$, 2.0 equiv) and CsF (243.0 mg, $1.6 \mathrm{mmol}$, 8.0 equiv) in MeCN (1.0 mL), the reaction mixture was stirred at rt for 24 hours. The yield (99\%) was determined by ${ }^{19} \mathrm{~F}$ NMR of the crude reaction mixture. The crude mixture was purified by column chromatography ( $n$-Hexane: EtOAc $=20: 1)$ to afford the title compound 1zf (25.6 mg, 66\% yield) as a colorless oil.

From alcohols: Following the general procedure D, using substrate $\mathbf{4 z f}$ (0.2 mmol, 1.0 equiv), TCCA (139.4 mg, $0.6 \mathrm{mmol}$, 3.0 equiv) and CsF (303.8 mg, $2.0 \mathrm{mmol}, 10.0$ equiv) in MeCN (1.0 mL), the reaction mixture was stirred at rt for 24 hours. The yield (78\%) was determined by ${ }^{19} \mathrm{~F}$ NMR of the crude reaction mixture. The crude mixture was purified by column chromatography ( $n$-Hexane: EtOAc $=20: 1)$ to afford the title compound 1zf (20.1 mg, 52\% yield) as a colorless oil.

${ }^{1} \mathbf{H}$ NMR (300 MHz, $\left.\mathrm{CDCl}_{3}\right)$ ): 8.13 (s, 1H), 7.89 (d, $\left.J=8.3 \mathrm{~Hz}, 1 \mathrm{H}\right), 7.64$ (d, $\left.J=8.4 \mathrm{~Hz}, 1 \mathrm{H}\right)$ ppm. ${ }^{19}$ F NMR $\left(282 \mathrm{MHz}, \mathrm{CDCl}_{3}\right) \delta: 18.64$ (s, 1F) ppm. ${ }^{13} \mathrm{C} \mathrm{NMR}\left(126 \mathrm{MHz}, \mathrm{CDCl}_{3}\right) \delta: 155.6\left(\mathrm{~d}, \mathrm{C}-\mathrm{F},{ }^{1} J_{\mathrm{C}-\mathrm{F}}=344.1 \mathrm{~Hz}\right)$, 140.5, 133.9 (d, $J=1.5 \mathrm{~Hz}), 133.1$ (d, C-F, $\left.{ }^{3} J_{\mathrm{C}-\mathrm{F}}=3.7 \mathrm{~Hz}\right), 131.3,130.2$ (d, C-F, $\left.{ }^{3} J_{\mathrm{C}-\mathrm{F}}=3.7 \mathrm{~Hz}\right), 124.6$ (d, CF, $\left.{ }^{2} J_{\mathrm{C}-\mathrm{F}}=63.9 \mathrm{~Hz}\right)$ ppm. IR (NaCl): 1817, 1588, 1468, 1385, 1278, 1034, 837, $745 \mathrm{~cm}^{-1}$. HRMS (EI) m/z: $[\mathrm{M}]^{+}$Calcd for $\mathrm{C}_{7} \mathrm{H}_{3} \mathrm{OFCl}_{2}{ }^{+}$191.9545; Found 191.9552 .<smiles>O=C(F)c1ccccn1</smiles>

\section{Picolinoyl fluoride (1zg).}

From aldehydes: Following the general procedure $\mathbf{C}$, using substrate $3 \mathbf{z g}$ (0.2 mmol, 1.0 equiv), TCCA (93.0 mg, $0.4 \mathrm{mmol}$, 2.0 equiv) and CsF (243.0 mg, $1.6 \mathrm{mmol}$, 8.0 equiv) in MeCN (1.0 mL), the reaction mixture was stirred at rt for 24 hours. The yield (73\%) was determined by ${ }^{19} \mathrm{~F}$ NMR of the crude reaction mixture. The crude mixture was washed with Hexane/DCM $(9: 1,5 \mathrm{~mL} \times 2)$ to afford the title compound $\mathbf{1 z g}(14.0 \mathrm{mg}, 56 \%$ yield) as a yellow oil.

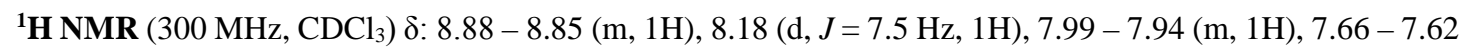
(m, 1H) ppm. ${ }^{19} \mathbf{F}$ NMR (282 MHz, $\left.\mathrm{CDCl}_{3}\right) \delta: 19.53$ (s, 1F) ppm. ${ }^{13} \mathbf{C}$ NMR (90 MHz, $\left.\mathrm{CDCl}_{3}\right) \delta: 156.4,154.6$ 
(d, C-F, $\left.{ }^{1} J_{\mathrm{C}-\mathrm{F}}=341.8 \mathrm{~Hz}\right), 150.8,137.5,128.7,127.4$ ppm. IR (NaCl): 3113, 1609, 1527, 1457, 1344, 836, 751, 683, $548 \mathrm{~cm}^{-1}$. HRMS (EI) m/z: [M] Calcd for $\mathrm{C}_{6} \mathrm{H}_{4} \mathrm{FNO}^{+}$125.0277; Found 125.0275.<smiles>O=C(F)c1cccnc1Br</smiles>

\section{2-Bromonicotinoyl fluoride (1zh).}

From aldehydes: Following the general procedure C, using substrate 3zh (0.2 mmol, 1.0 equiv), TCCA (93.0 mg, $0.4 \mathrm{mmol}$, 2.0 equiv) and CsF (243.0 mg, $1.6 \mathrm{mmol}, 8.0$ equiv) in MeCN (1.0 mL), the reaction mixture was stirred at rt for 24 hours. The yield (95\%) was determined by ${ }^{19} \mathrm{~F}$ NMR of the crude reaction mixture. The crude mixture was washed with Hexane/DCM $(9: 1,5 \mathrm{~mL} \times 2)$ to afford the title compound 1zh (35.8mg, 88\% yield) as a white solid.

From alcohols: Following the general procedure D, using substrate 4zh (0.2 mmol, 1.0 equiv), TCCA (139.4 mg, $0.6 \mathrm{mmol}, 3.0$ equiv) and CsF (303.8 mg, $2.0 \mathrm{mmol}, 10.0$ equiv) in MeCN (1.0 mL), the reaction mixture was stirred at rt for 24 hours. The yield (80\%) was determined by ${ }^{19} \mathrm{~F}$ NMR of the crude reaction mixture. The crude mixture was washed with Hexane/DCM $(9: 1,5 \mathrm{~mL} \times 2)$ to afford the title compound 1zh (25.8 mg, 64\% yield) as a white solid.

m.p.: 96.6 - $97.4^{\circ} \mathrm{C} .{ }^{1} \mathbf{H}$ NMR (300 MHz, $\left.\mathrm{CDCl}_{3}\right) \delta: 8.64$ (dd, $\left.J=4.5,1.8 \mathrm{~Hz}, 1 \mathrm{H}\right), 8.32$ - 8.29 (m, 1H), 7.48 (dd, $J=7.7,4.8 \mathrm{~Hz}, 1 \mathrm{H})$ ppm. ${ }^{19} \mathbf{F}$ NMR $\left(282 \mathrm{MHz}, \mathrm{CDCl}_{3}\right) \delta: 31.58(\mathrm{~s}, 1 \mathrm{~F}) \mathrm{ppm} .{ }^{13} \mathbf{C ~ N M R}\left(126 \mathrm{MHz}, \mathrm{CDCl}_{3}\right)$

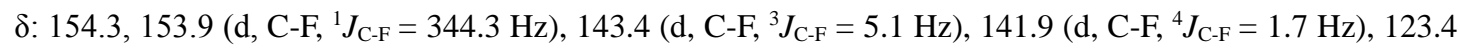
(d, C-F, $\left.{ }^{2} J_{\mathrm{C}-\mathrm{F}}=64.6 \mathrm{~Hz}\right), 122.6$ ppm. IR (KBr): 3051, 2928, 2845, 1822, 1577, 1405, 1274, 1096, 994, 792, 754, $410 \mathrm{~cm}^{-1}$. HRMS (EI) m/z: [M] Calcd for $\mathrm{C}_{6} \mathrm{H}_{3} \mathrm{NOFBr}^{+}$202.9382; Found 202.9384 .<smiles>O=CC1CC1</smiles>

3zi

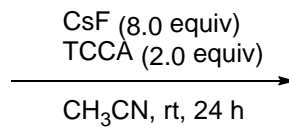

$\mathrm{CH}_{3} \mathrm{CN}, \mathrm{rt}, 24 \mathrm{~h}$

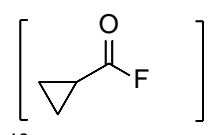

${ }^{19}$ F NMR d: 32.69 ppm

$1 z$

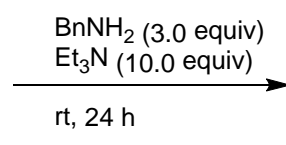

rt, $24 \mathrm{~h}$

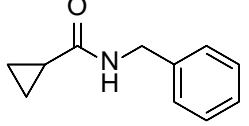

$5 z i$

\section{N-Benzylcyclopropanecarboxamide (5zi).}

From aldehydes: Following the general procedure C, using substrate 3zi (0.2 mmol, 1.0 equiv), TCCA (93.0 mg, $0.4 \mathrm{mmol}, 2.0$ equiv) and CsF (243.0 mg, $1.6 \mathrm{mmol}, 8.0$ equiv) in MeCN (1.0 mL), the reaction mixture was stirred at rt for 24 hours. Then $\mathrm{Et}_{3} \mathrm{~N}\left(279 \mu \mathrm{L}, 2.0 \mathrm{mmol}, 10.0\right.$ equiv) and $\mathrm{BnNH}_{2}(65.5 \mu \mathrm{L}, 0.6 \mathrm{mmol}, 3.0$ equiv) were added to the reaction mixture and the mixture was stirred at room temperature overnight. After quenching with $\mathrm{H}_{2} \mathrm{O}(5 \mathrm{~mL})$, the mixture was extracted with AcOEt $(3 \times 10 \mathrm{~mL})$ and the combined organic layer was dried over anhydrous $\mathrm{Na}_{2} \mathrm{SO}_{4}$, filtered and concentrated under reduced pressure. The crude residue was purified by silica gel flash chromatography ( $n$-Hexane: AcOEt $=3: 1$ to $1: 1)$ to afford the title compound 5zi (27.3 mg, 78\% yield) as a white solid. 
${ }^{1} \mathbf{H}$ NMR (300 MHz, $\mathrm{CDCl}_{3}$ ) $\delta: 7.32-7.29$ (m, 5H), 5.88 (s, 1H), 4.47 (d, $\left.J=5.5 \mathrm{~Hz}, 2 \mathrm{H}\right), 1.38-1.31$ (m, 1H), $1.03-0.98(\mathrm{~m}, 2 \mathrm{H}), 0.77-0.74(\mathrm{~m}, 2 \mathrm{H}) \mathrm{ppm}$. MS (ESI): m/z $176[\mathrm{M}+\mathrm{H}]^{+}$Spectroscopic data was agreement with the literature. ${ }^{[10]}$

*1zi NMR yields (>99\%) were directly determined by ${ }^{19} \mathrm{~F}$ NMR analysis of the crude products using $\mathrm{C}_{6} \mathrm{H}_{5} \mathrm{~F}$ (19.0 $\mu \mathrm{L}, 0.2 \mathrm{mmol}, 1.0$ equiv) as an internal standard. ${ }^{19} \mathrm{~F}$ NMR $\left(282 \mathrm{MHz}, \mathrm{CDCl}_{3}\right) \delta: 32.69(\mathrm{~d}, J=5.7 \mathrm{~Hz})$ ppm.<smiles>O=C(F)C1=NOC(c2ccccc2)(c2ccccc2)C1</smiles>

\section{5,5-Diphenyl-4,5-dihydroisoxazole-3-carbonyl fluoride (1zj).}

From aldehydes: Following the general procedure C, using substrate 3zj (0.2 mmol, 1.0 equiv), TCCA (93.0 mg, $0.4 \mathrm{mmol}$, 2.0 equiv) and CsF (243.0 mg, $1.6 \mathrm{mmol}, 8.0$ equiv) in MeCN (1.0 mL), the reaction mixture was stirred at rt for 24 hours. The yield (81\%) was determined by ${ }^{19} \mathrm{~F}$ NMR of the crude reaction mixture. The crude mixture was washed with Hexane $(5 \mathrm{~mL} \times 2)$ to afford the title compound $\mathbf{1 z j}(36.5 \mathrm{mg}, 68 \%$ yield) as a yellow oil.

From alcohols: Following the general procedure D, using substrate 4zj (0.2 mmol, 1.0 equiv), TCCA (139.4 mg, $0.6 \mathrm{mmol}$, 3.0 equiv) and CsF (303.8 mg, $2.0 \mathrm{mmol}, 10.0$ equiv) in MeCN (1.0 mL), the reaction mixture was stirred at rt for 24 hours. The yield (68\%) was determined by ${ }^{19} \mathrm{~F}$ NMR of the crude reaction mixture. The crude mixture was washed with Hexane $(5 \mathrm{~mL} \times 2)$ to afford the title compound $\mathbf{1 z j} 15.3 \mathrm{mg}$, 28\% yield) as a yellow oil.

${ }^{1} \mathbf{H}$ NMR (300 MHz, $\left.\mathrm{CDCl}_{3}\right) \delta: 7.40$ - 7.30 (m, 10H), 3.85 (s, 2H) ppm. ${ }^{19}$ F NMR (282 MHz, CDCl $) \delta: 25.81$ (s, 1F) ppm. ${ }^{13} \mathrm{C}$ NMR (176 MHz, CDCl $) \delta: 150.8$ (d, C-F, $\left.{ }^{1} J_{\mathrm{C}-\mathrm{F}}=345.6 \mathrm{~Hz}\right), 147.2\left(\mathrm{~d}, \mathrm{C}-\mathrm{F},{ }^{2} J_{\mathrm{C}-\mathrm{F}}=61.8 \mathrm{~Hz}\right)$, 142.0, 128.7, 128.4, 125.8, 97.1, 45.4 ppm. IR (NaCl): 3063, 3027, 1813, 1731, 1583, 1448, 1270, 1051, 976, 932, 758, $699 \mathrm{~cm}^{-1}$. HRMS (EI) m/z: [M] Calcd for $\mathrm{C}_{16} \mathrm{H}_{12} \mathrm{FNO}_{2}{ }^{+}$269.0852; Found 269.0853.

\section{Scale-up Procedure for the Synthesis of $1 \mathrm{~d}$ with $2 \mathrm{~d}$.}<smiles>O=C(F)c1ccc(Br)cc1</smiles>

\section{4-Bromobenzoyl fluoride (1d).}

From carboxylic acids: Following the general procedure A, using substrate 2d (1.0 mmol, 1.0 equiv), TCCA (465.0 mg, $2.0 \mathrm{mmol}, 2.0$ equiv) and CsF (1.215 g, $8.0 \mathrm{mmol}, 8.0$ equiv) in MeCN (5.0 mL), the reaction mixture was stirred at rt for 24 hours. The yield (87\%) was determined by ${ }^{19} \mathrm{~F}$ NMR of the crude reaction mixture. The crude mixture was purified by column chromatography ( $n$-Hexane: EtOAc $=20: 1)$ to afford the title compound 1d (159.6 mg, 79\% yield) as a white solid. 
Scale-up Procedure for the Synthesis of $\mathbf{1} \mathbf{j}$ with $\mathbf{3} \mathbf{j}$.<smiles>CC(C)(C)c1ccc(C(=O)F)cc1</smiles>

\section{4-(tert-Butyl)benzoyl fluoride (1j).}

From aldehydes: Following the general procedure $\mathbf{C}$, using substrate $\mathbf{3 j}$ ( $1.0 \mathrm{mmol}$, 1.0 equiv), TCCA (465.0 $\mathrm{mg}, 2.0 \mathrm{mmol}$, 2.0 equiv) and CsF (1.215 g, $8.0 \mathrm{mmol}, 8.0$ equiv) in MeCN (5.0 mL), the reaction mixture was stirred at rt for 24 hours. The yield (71\%) was determined by ${ }^{19} \mathrm{~F}$ NMR of the crude reaction mixture. The crude mixture was purified by column chromatography ( $n$-Pentane: $\left.\mathrm{Et}_{2} \mathrm{O}=50: 1\right)$ to afford the title compound $\mathbf{1 j}$ (103.5 mg, 57\% yield) as a colorless oil.

\section{Scale-up Procedure for the Synthesis of 1c with 4c.}<smiles>O=C(F)c1ccc(Cl)cc1</smiles>

\section{4-Chlorobenzoyl fluoride (1c).}

Following the general procedure $\mathbf{D}$, using substrate $4 \mathbf{c}$ (1.0 mmol, 1.0 equiv), TCCA (697.0 mg, $3.0 \mathrm{mmol}, 3.0$ equiv) and CsF (1.519 g, $10.0 \mathrm{mmol}, 10.0$ equiv) in $\mathrm{MeCN}(5.0 \mathrm{~mL})$, the reaction mixture was stirred at rt for 24 hours. The yield (90\%) was determined by ${ }^{19} \mathrm{~F}$ NMR of the crude reaction mixture. The crude mixture was purified by column chromatography ( $n$-Hexane: EtOAc $=20: 1)$ to afford the title compound 1c $(129.1 \mathrm{mg}$, $81 \%$ yield) as a pale yellow solid.

\section{Preparation of Starting Materials}

Carboxylic acids $\mathbf{2 a}-\mathbf{2} \mathbf{w}$ were known compounds and obtained from commercial sources. $\mathbf{2} \mathbf{x}^{11}$ was known compounds and synthesized according to the reported procedures. Aldehydes $\mathbf{3 a}-\mathbf{3 g}, \mathbf{3 i}-$ 3k, 3o - 3p, 3s, 3v, and 3y - 3zi were known compounds and obtained from commercial sources. $3 \mathbf{w}^{12}$ and $\mathbf{3 z} \mathbf{j}^{13}$ were known compounds and synthesized according to the reported procedures. Alcohols $4 \mathbf{a}-\mathbf{4 g}, \mathbf{4 i}-\mathbf{4 j}, \mathbf{4 o}, \mathbf{4 z}, \mathbf{4 z b}, \mathbf{4 z f}$, and $4 \mathbf{z h}$ were known compounds and obtained from commercial sources. $\mathbf{4 z j}{ }^{13}$ was known compounds and synthesized according to the reported procedures. 


\section{Detection of $\mathrm{O}_{2}$ in the Process of Oxidative Fluorination Reaction of Carboxylic Acids}

An oven-dried narrow-mouth FEP tube (Nalgene $\left.{ }^{\circledR}\right)(10.0 \mathrm{~mL})$ containing a magnetic stir bar was charged with carboxylic acid 2a (0.6 mmol), TCCA (279.0 mg, $1.2 \mathrm{mmol}$, 2.0 equiv) and CsF (729.1 mg, $4.8 \mathrm{mmol}$, 8.0 equiv) in anhydrous $\mathrm{MeCN}(3.0 \mathrm{~mL}, 0.2 \mathrm{M}$ ) in a nitrogen-filled glovebox. The tube was connected with a thin tube and a needle to another bottle filled with a fresh aqueous solution of $\mathrm{Fe}(\mathrm{OH})_{2}$, then stirred at room temperature overnight. The turbid green solution became dark, then brown $\mathrm{Fe}(\mathrm{OH})_{3}$ precipitate was observed. It indicates that $\mathrm{O}_{2}$ was generated during the oxidative fluorination reaction of the carboxylic acid with TCCA and CsF.

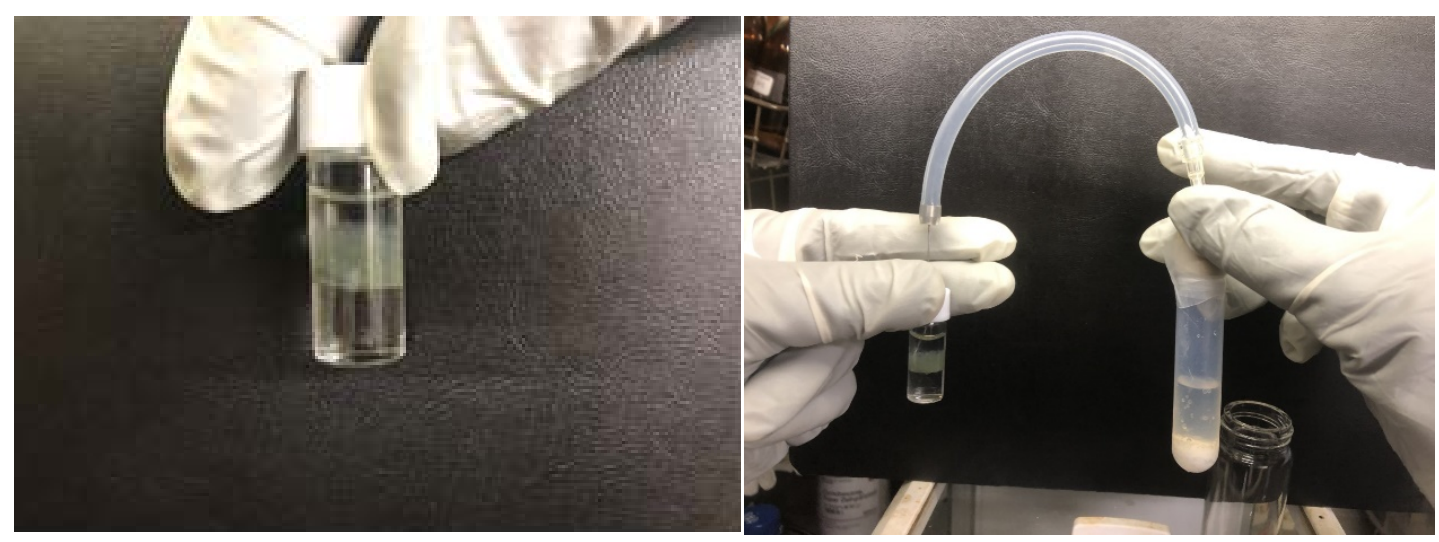

The fresh green solution of $\mathrm{Fe}(\mathrm{OH})_{2}$ (left). Transferring the gas, generated in the reaction mixture, into another tube filled with a fresh aqueous $\mathrm{Fe}(\mathrm{OH})_{2}$ (right) solution.

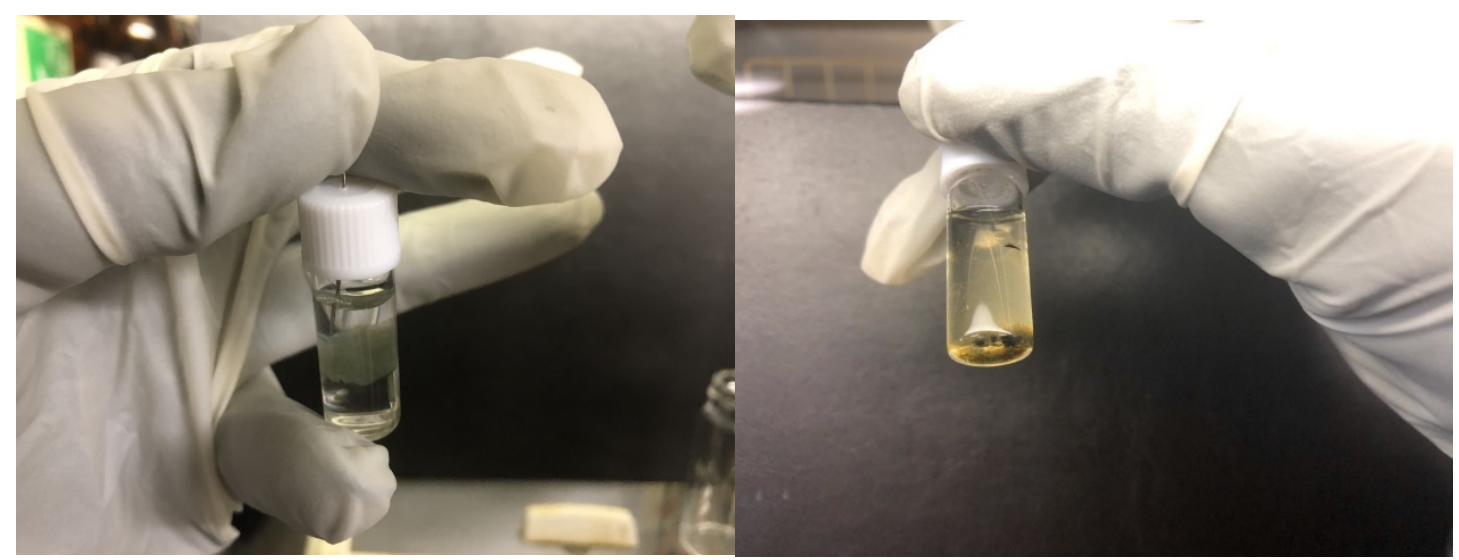

After bubbling the gas generated in the reaction mixture, the color of solution started to change (left). The brown $\mathrm{Fe}(\mathrm{OH})_{3}$ precipitate was observed (right). It indicates the formation of $\mathrm{Fe}(\mathrm{OH})_{3}$. 
6. The Linear Relationship between Yield and ReactioTime of $2 a$.<smiles>O=C(O)c1ccccc1</smiles>

$2 a$

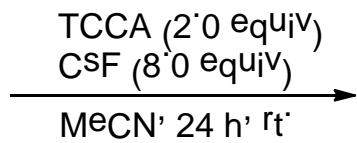

MeCN' 24 h' rt<smiles>O=C(F)c1ccccc1</smiles>

$1 \mathbf{a}$

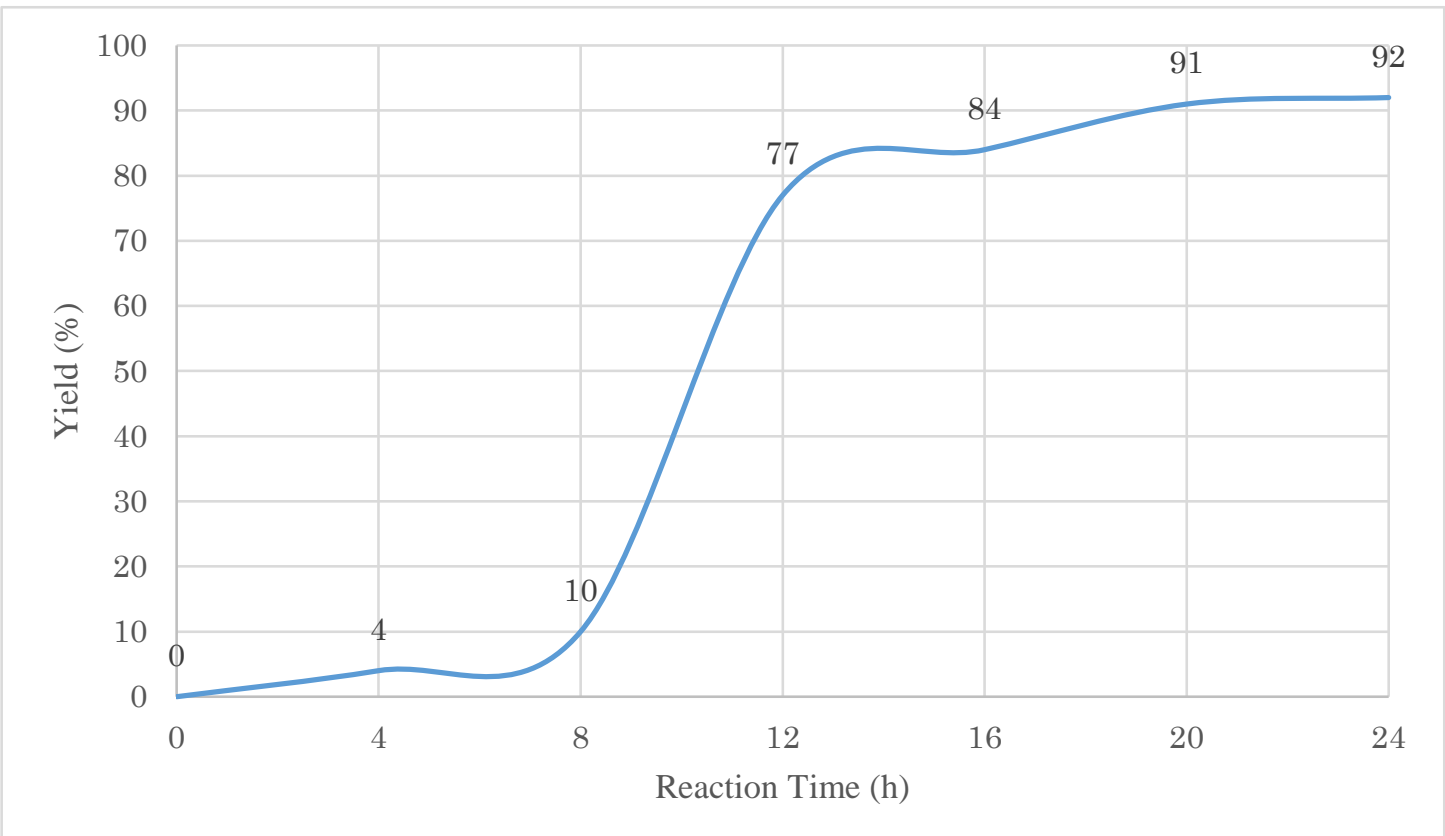

From the linear relationship, it can be seen that the reaction is slow at first, then reaction is rapid in the middle of a period of time, and finally the reaction speed is flattened again.

\section{References}

1. Liang, Y.; Zhao, Z.; Shibata, N. Commun. Chem., 2020, 3, 59.

2. Scattolin, T.; Deckers, K.; Schoenebeck, F. Org. Lett., 2017, 19, 5740-5743.

3. Han, J.; Zhou, W.; Zhang, P. C.; Wang, H.; Zhang, R.; Wu, H. H.; Zhang, J. ACS Catal., 2019, 9, 68906895.

4. Malapit, C. A.; Bour, J. R.; Brigham, C. E.; Sanford, M. S. Nature, 2018, 563, 100.

5. Banks, R. E.; Mothersdale, K. N.; Tipping, A. E.; Tsilipoulos, E.; Cozens, B. J.; Wotton, D. E.; Tatlow, J. C. J. Fluorine Chem., 1990, 46, 529-537.

6. Meanwell, M.; Lehmann, J.; Eichenberger, M.; Martin, R. E.; Britton, R. Chem. Commun. 2018, 54, 99859988.

7. Umemoto, T.; Singh, R. P.; Xu, Y.; Saito, N. J. Am. Chem. Soc. 2010, 132, 18199-18205.

8. Kunshenko, B. V.; Omarov, V. O.; Muratov, N. N.; Mikhailevskii, S. M.; Yagupolskii, L. M. Zh. Org. Khim., 1991, 27, 125-129.

9. Lee, G. M.; Clément, R.; Baker, R. T. Catal. Sci. Technol., 2017, 7, 4996-5003.

10. Levernier, E.; Corcé, V.; Rakotoarison, L. M.; Smith, A.; Zhang, M.; Ognier, S.; Tatoulian, M.; Ollivier, C.; Fensterbank, L. Org. Chem. Front., 2019, 6, 1378-1382.

11. Lesma, G.; Sacchetti, A.; Silvani, A. Synthesis., 2006, 4, 594-596.

12. Nielsen, M. K.; Ahneman, D. T.; Riera, O.; Doyle A. G. J. Am. Chem. Soc., 2018, 140, 5004-5008.

13. Cremonesi, G.; Croce, P. D.; Fontana, F.; Fiorelli, C.; La Rosa, C. Tetrahedron: Asymmetry 2008, 19, 2850-2855. 
8. ${ }^{1} \mathrm{H}$ NMR Spectra, ${ }^{19} \mathrm{~F}$ NMR Spectra and ${ }^{13} \mathrm{C}$ NMR Spectra

Benzoyl fluoride (1a).

${ }^{1} \mathrm{H}$ NMR (300 MHz, $\mathrm{CDCl}_{3}$ )<smiles>O=C(F)c1ccccc1</smiles>
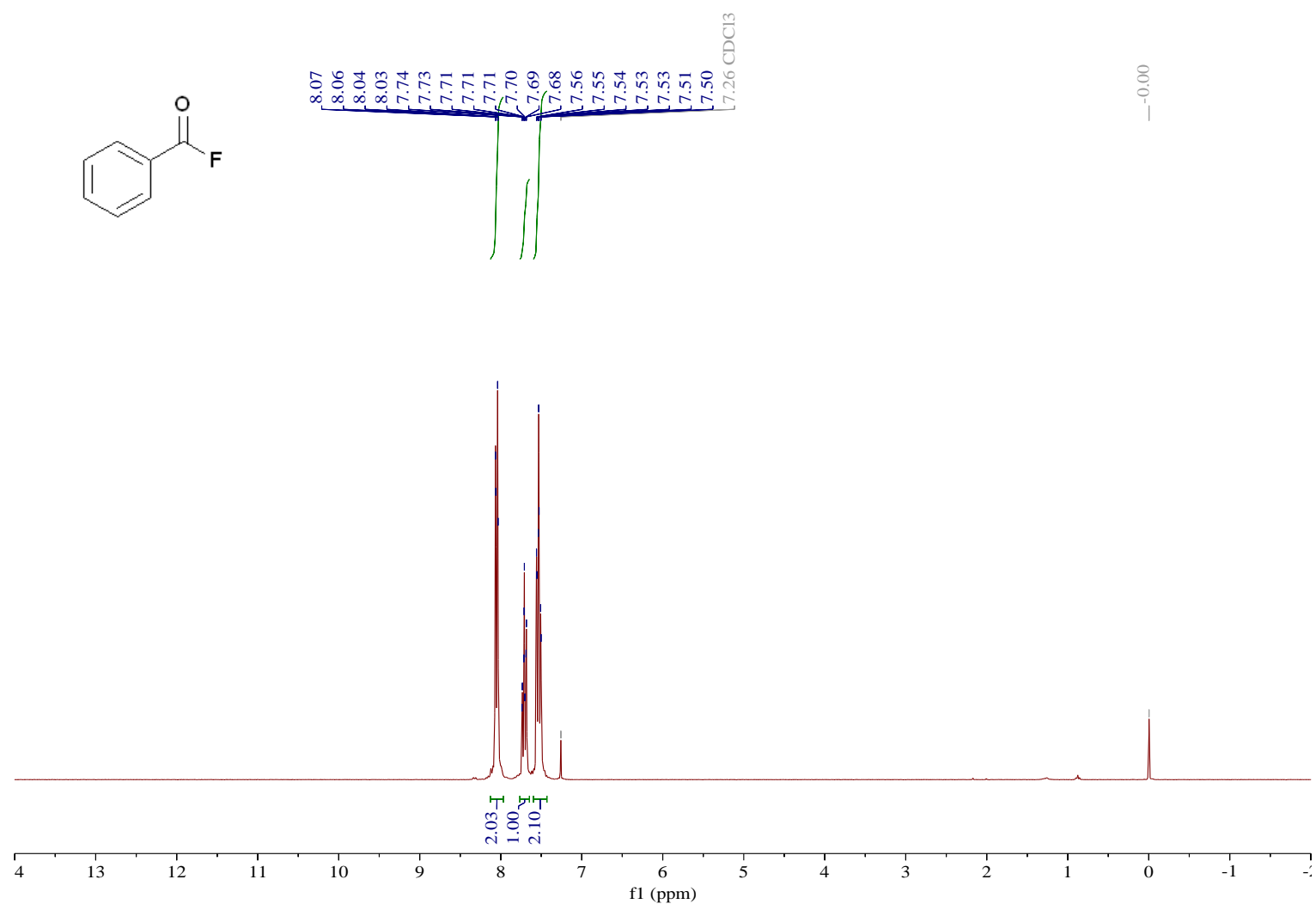

${ }^{19}$ F NMR (282 MHz, $\left.\mathrm{CDCl}_{3}\right)$<smiles>O=C(F)c1ccccc1</smiles>

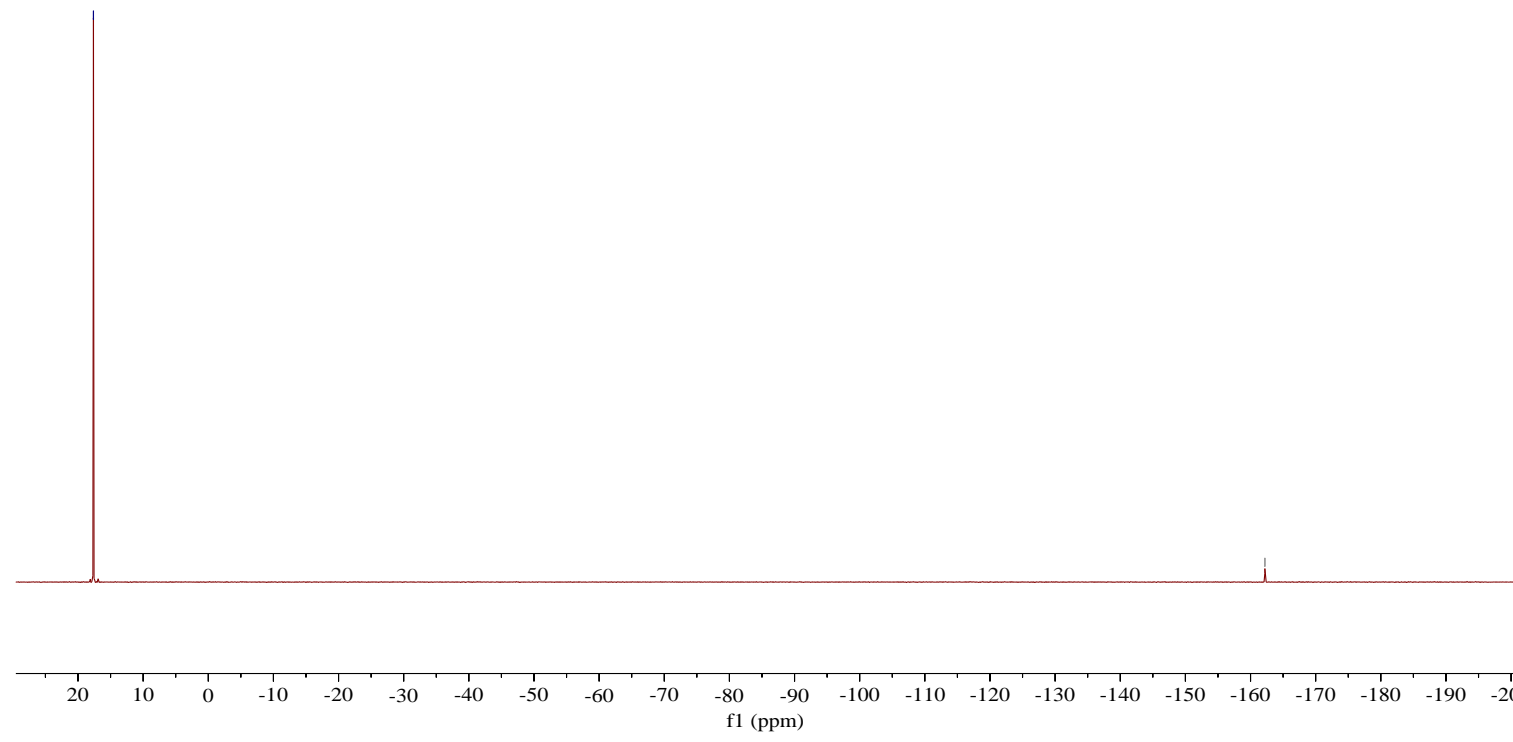


4-Fluorobenzoyl fluoride (1b).

${ }^{1} \mathrm{H}$ NMR (300 MHz, $\mathrm{CDCl}_{3}$ )<smiles>O=C(F)c1ccc(F)cc1</smiles>

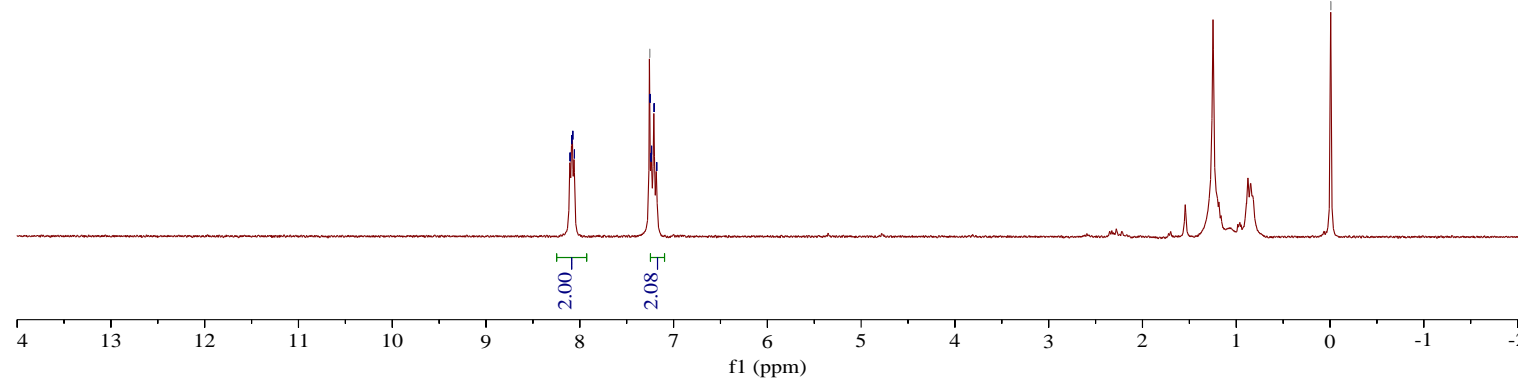

${ }^{19}$ F NMR (282 MHz, CDCl 3 )<smiles>N#Cc1ccc(C(=O)F)cc1</smiles>

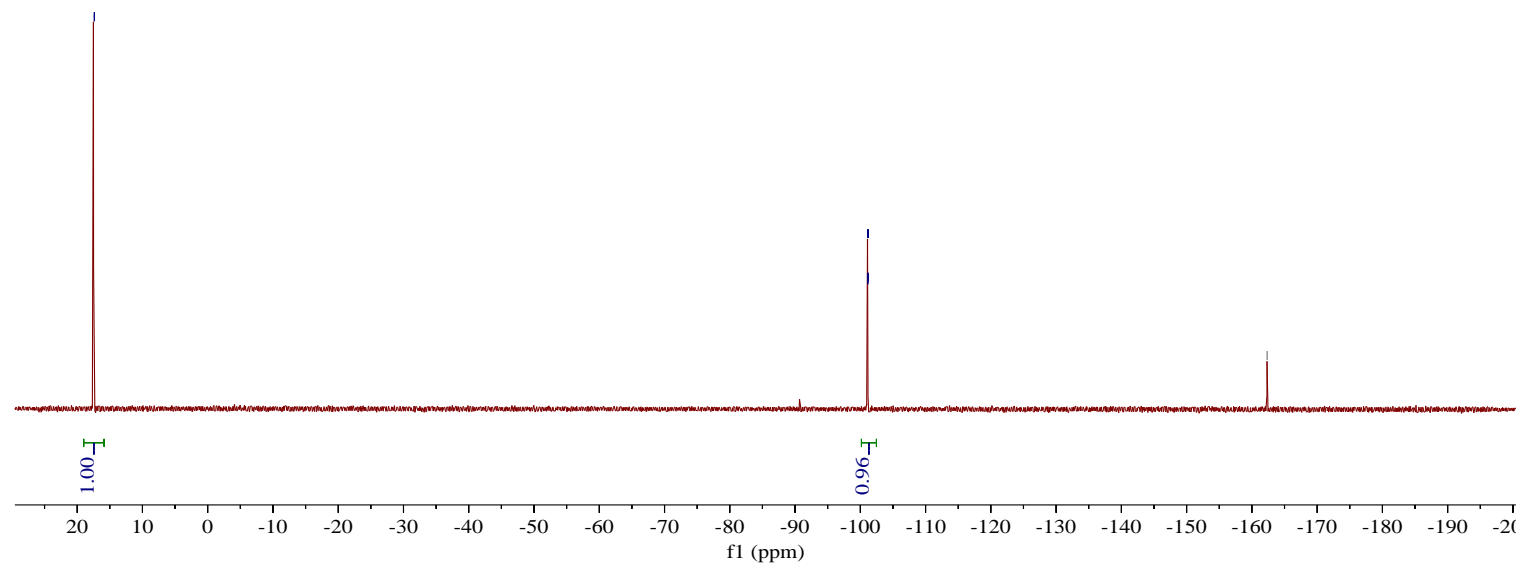


4-Chlorobenzoyl fluoride (1c).

${ }^{1} \mathrm{H}$ NMR (300 MHz, $\left.\mathrm{CDCl}_{3}\right)$<smiles>O=C(F)c1ccc(Cl)cc1</smiles>
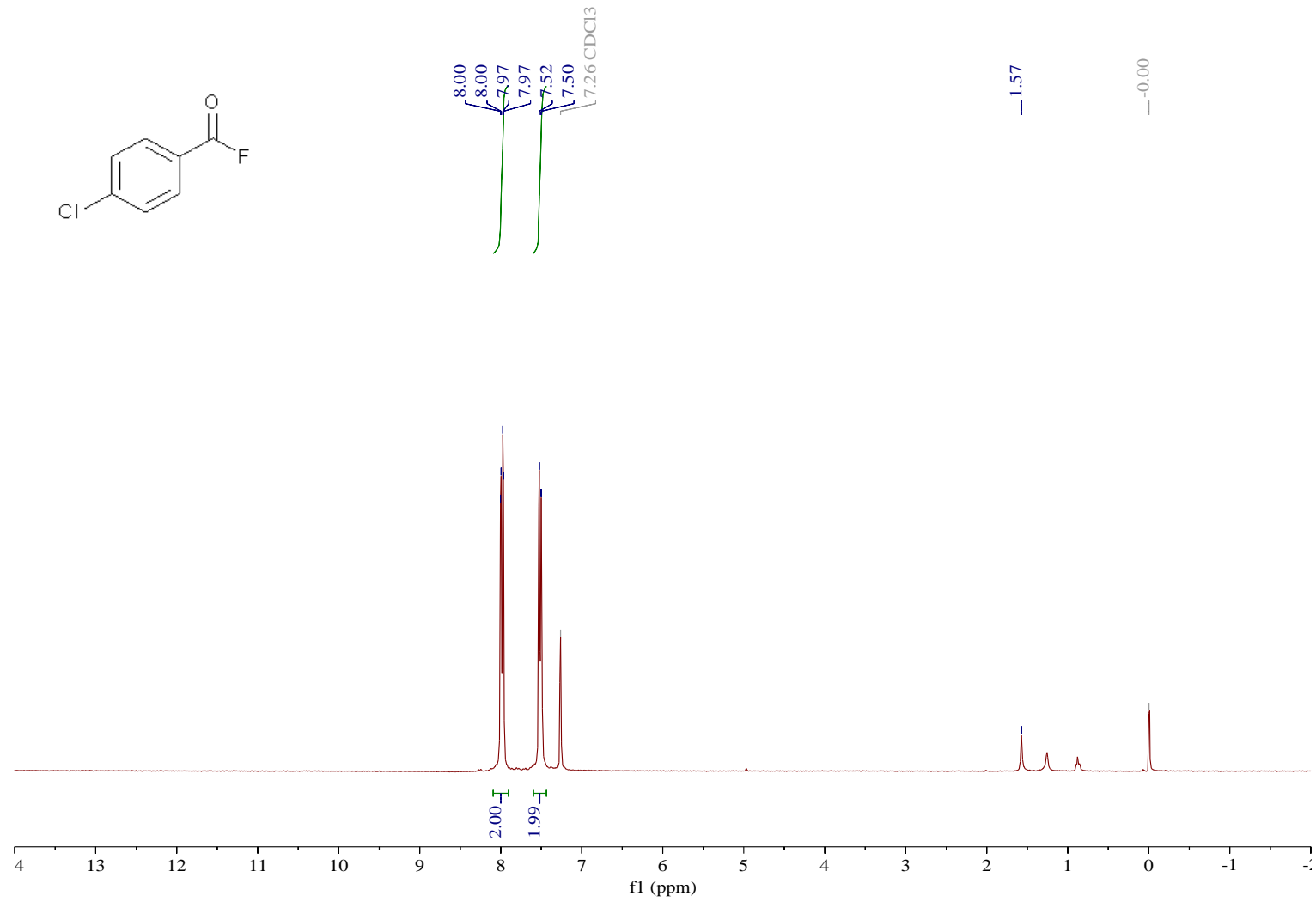

${ }^{19}$ F NMR (282 MHz, $\left.\mathrm{CDCl}_{3}\right)$

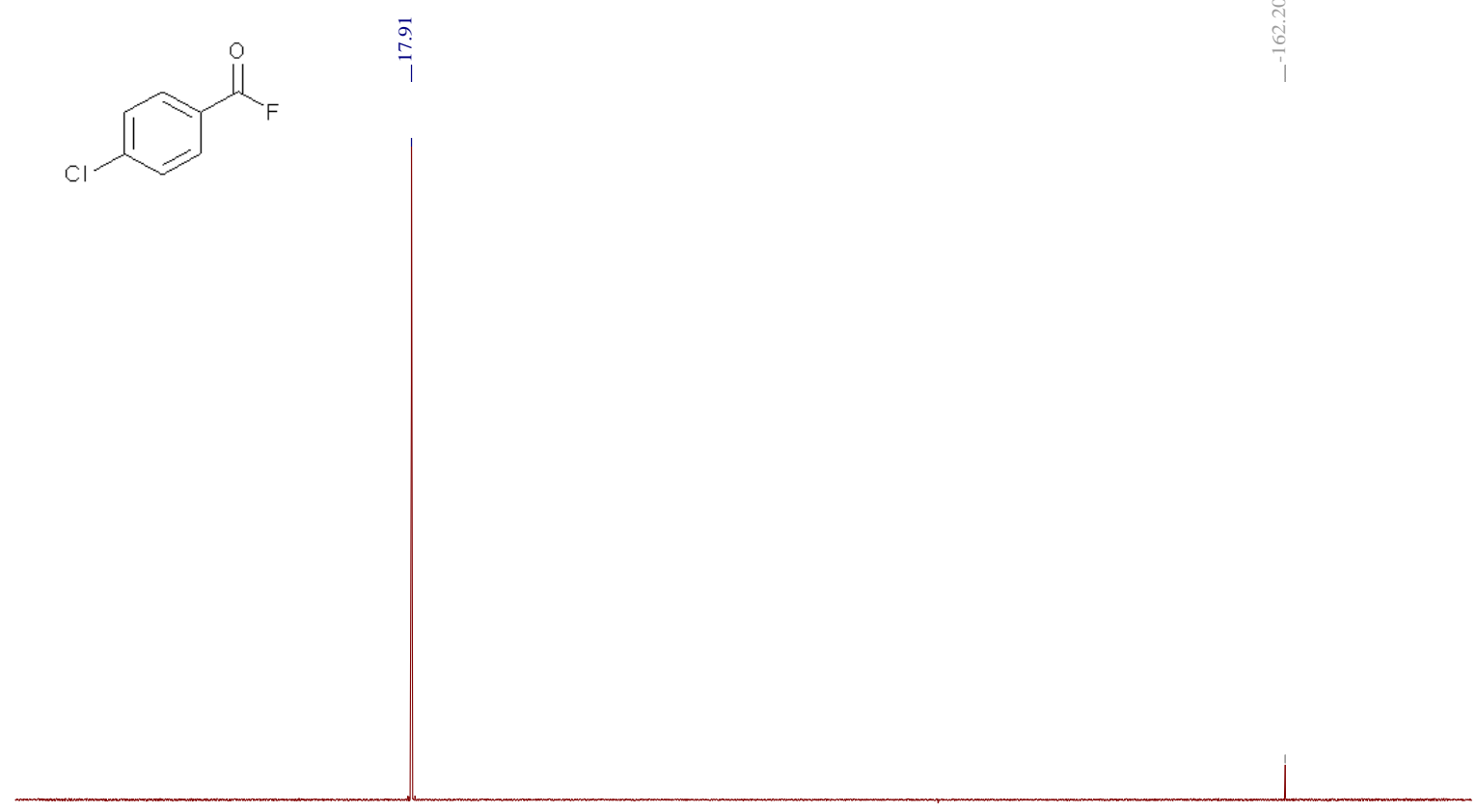

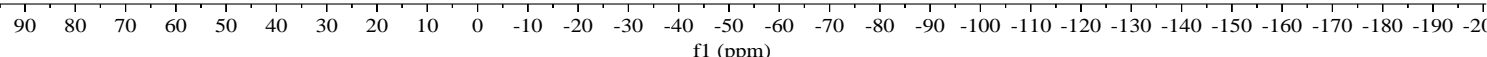


4-Bromobenzoyl fluoride (1d).

${ }^{1} \mathrm{H}$ NMR (300 MHz, $\left.\mathrm{CDCl}_{3}\right)$
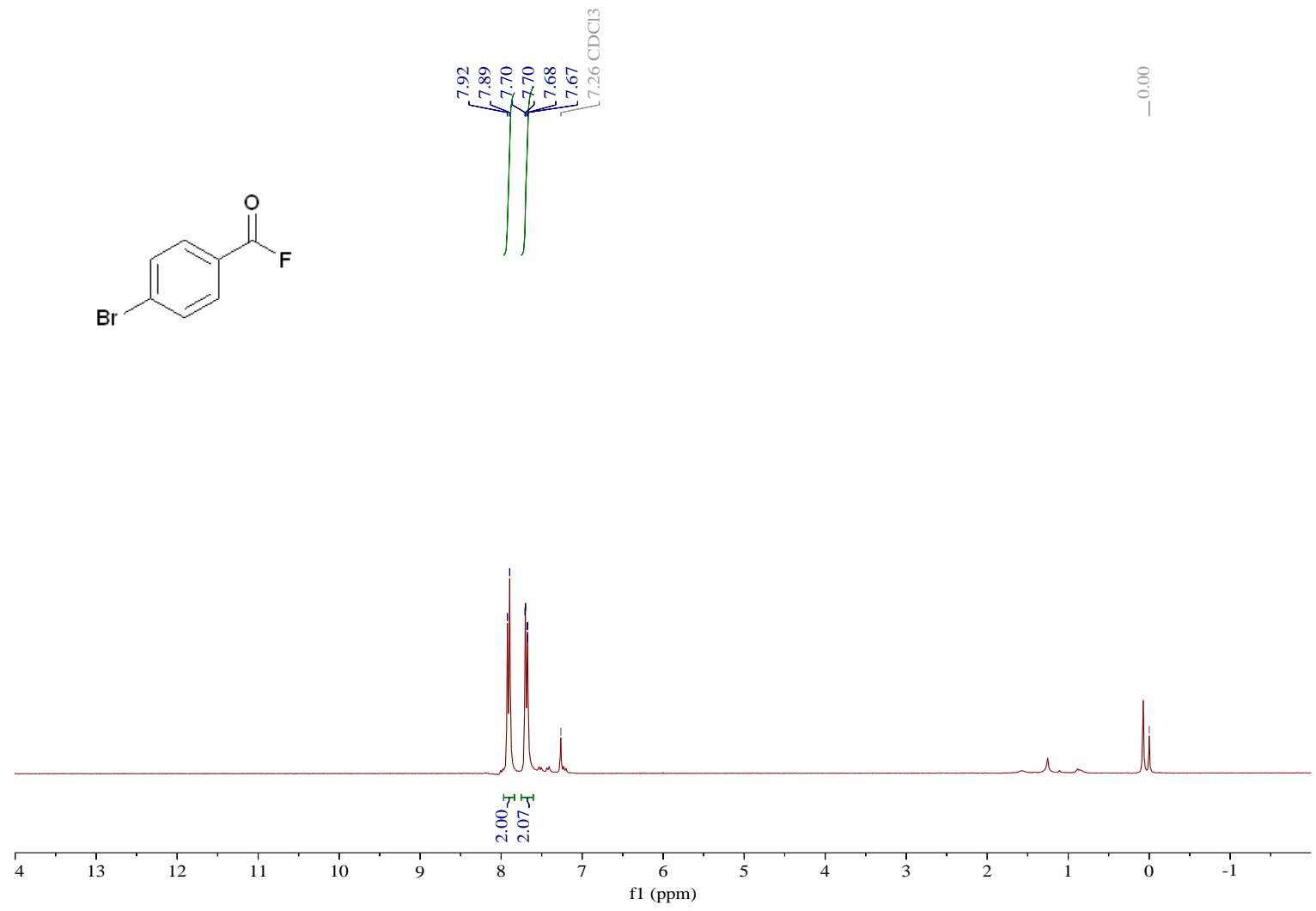

${ }^{19}$ F NMR (282 MHz, $\left.\mathrm{CDCl}_{3}\right)$

$\stackrel{\vec{\sigma}}{\stackrel{7}{+}}$

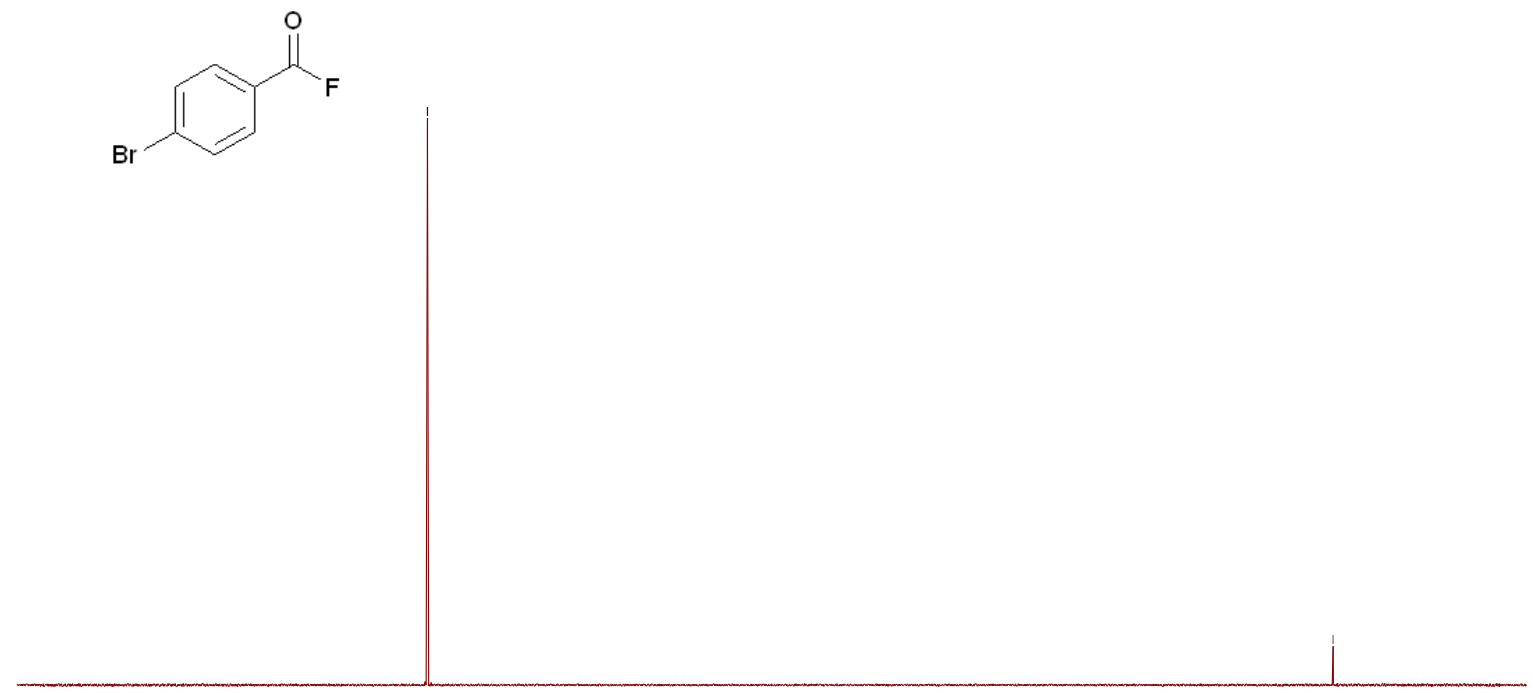

$\begin{array}{llllllllllllllllllllllllllllllllllllllll}90 & 80 & 70 & 60 & 50 & 40 & 30 & 20 & 10 & 0 & -10 & -20 & -30 & -40 & -50 & -60 & -70 & -80 & -90 & -100 & -110 & -120 & -130 & -140 & -150 & -160 & -170 & -180 & -190 & -2(\end{array}$ 
4-Nitrobenzoyl fluoride (1e).

${ }^{1} \mathrm{H}$ NMR (300 MHz, $\left.\mathrm{CDCl}_{3}\right)$<smiles>O=C(F)c1ccc([N+](=O)[O-])cc1</smiles>

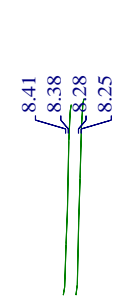

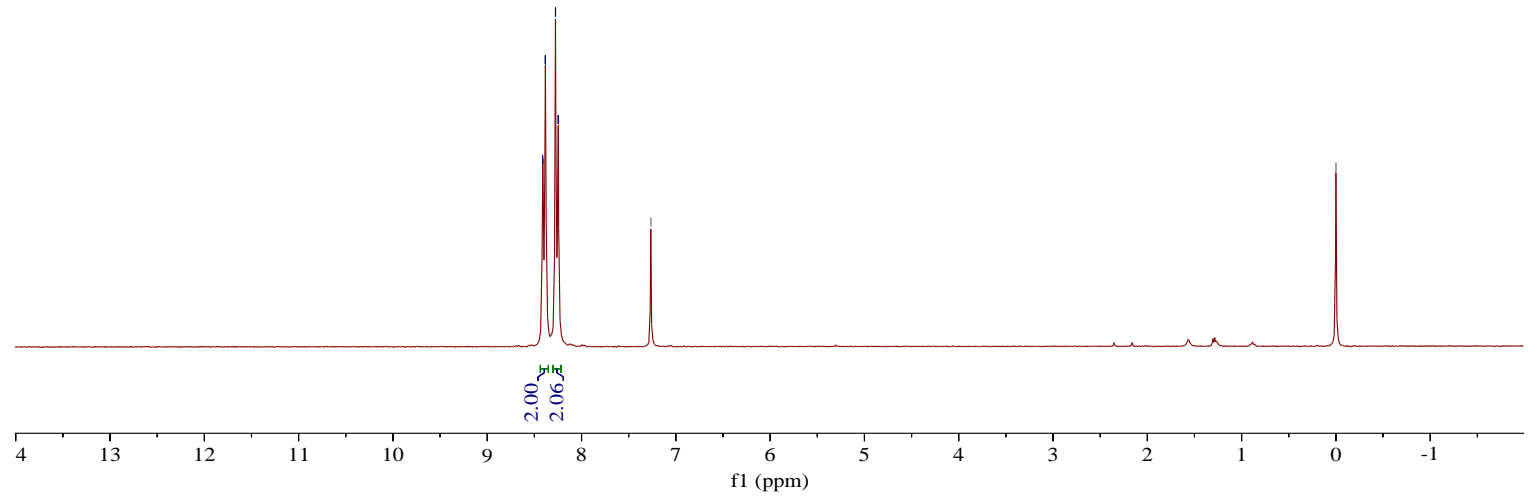

${ }^{19}$ F NMR (282 MHz, $\left.\mathrm{CDCl}_{3}\right)$

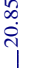<smiles>O=C(F)c1ccc([N+](=O)[O-])cc1</smiles>

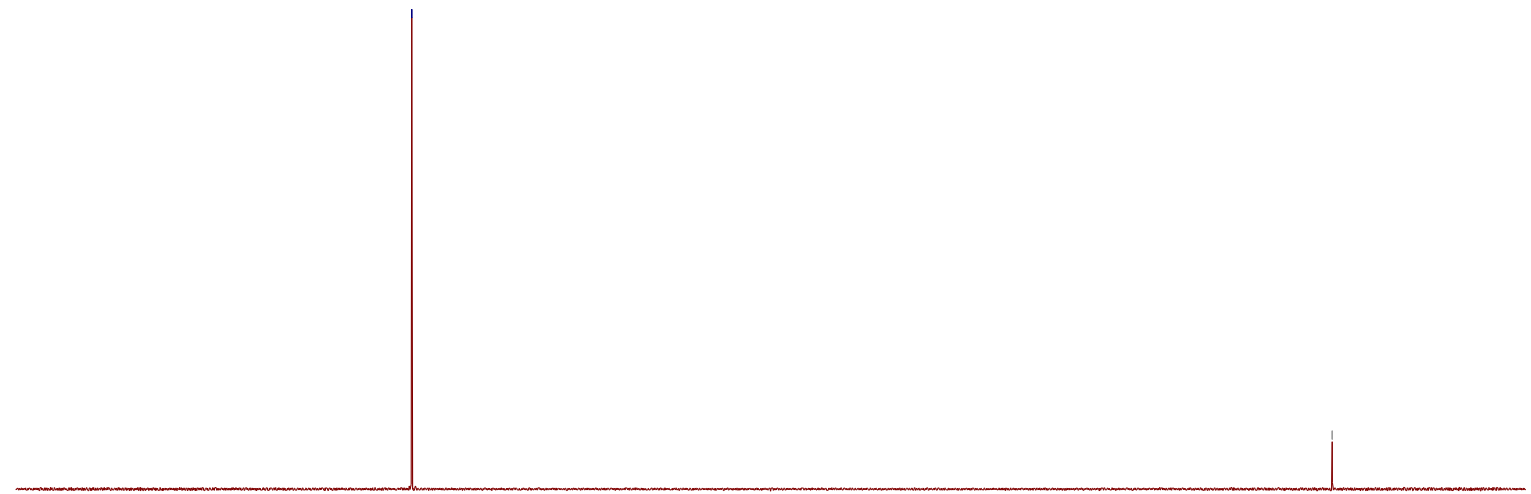

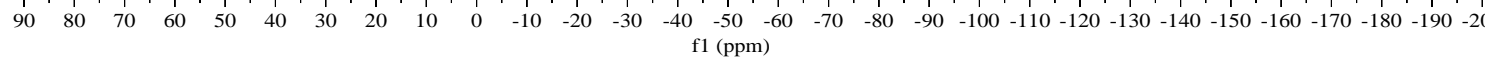


4-(Trifluoromethyl)benzoyl fluoride fluoride (1f).

${ }^{1} \mathrm{H}$ NMR (300 MHz, $\mathrm{CDCl}_{3}$ )
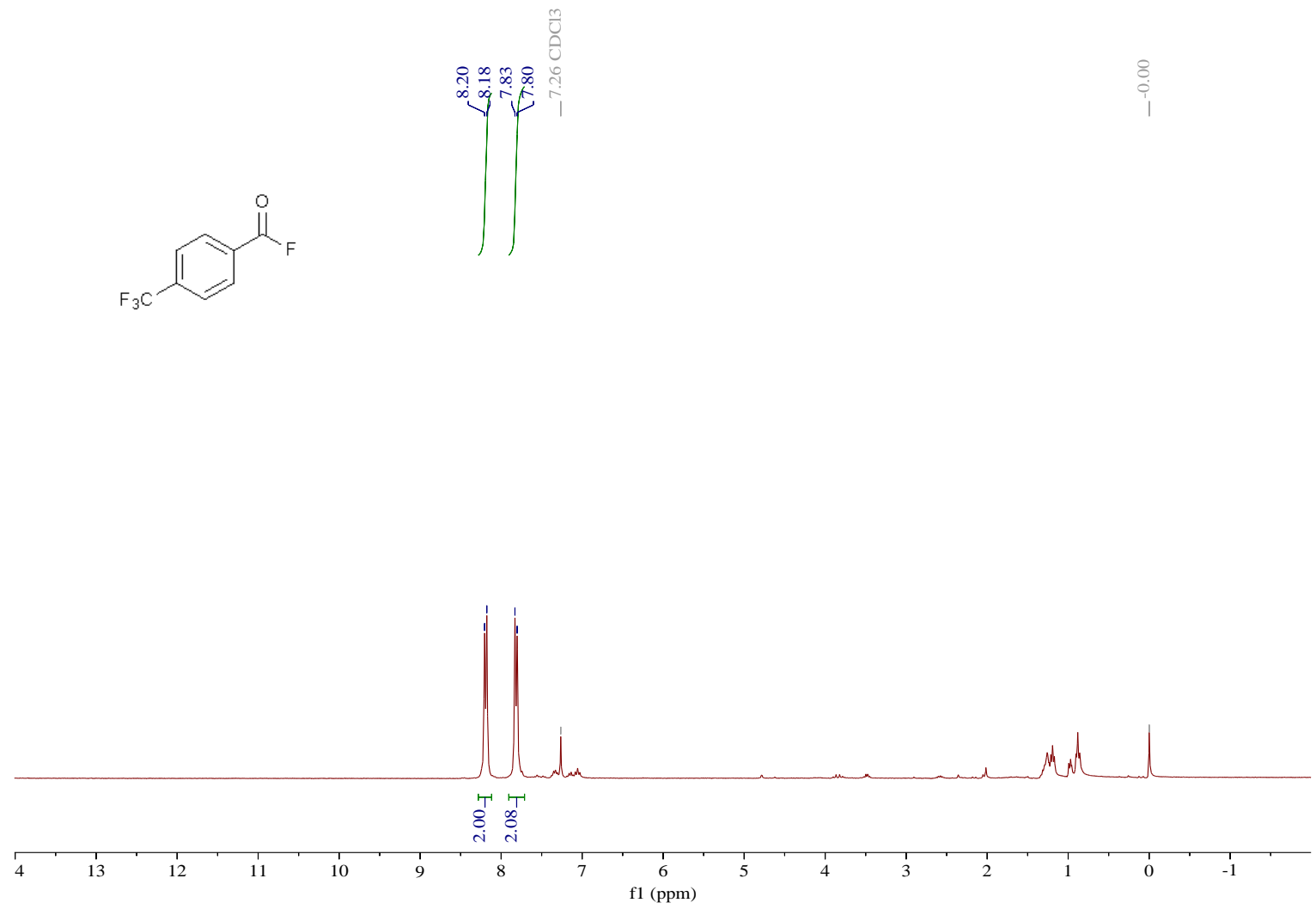

${ }^{19}$ F NMR (282 MHz, $\mathrm{CDCl}_{3}$ )
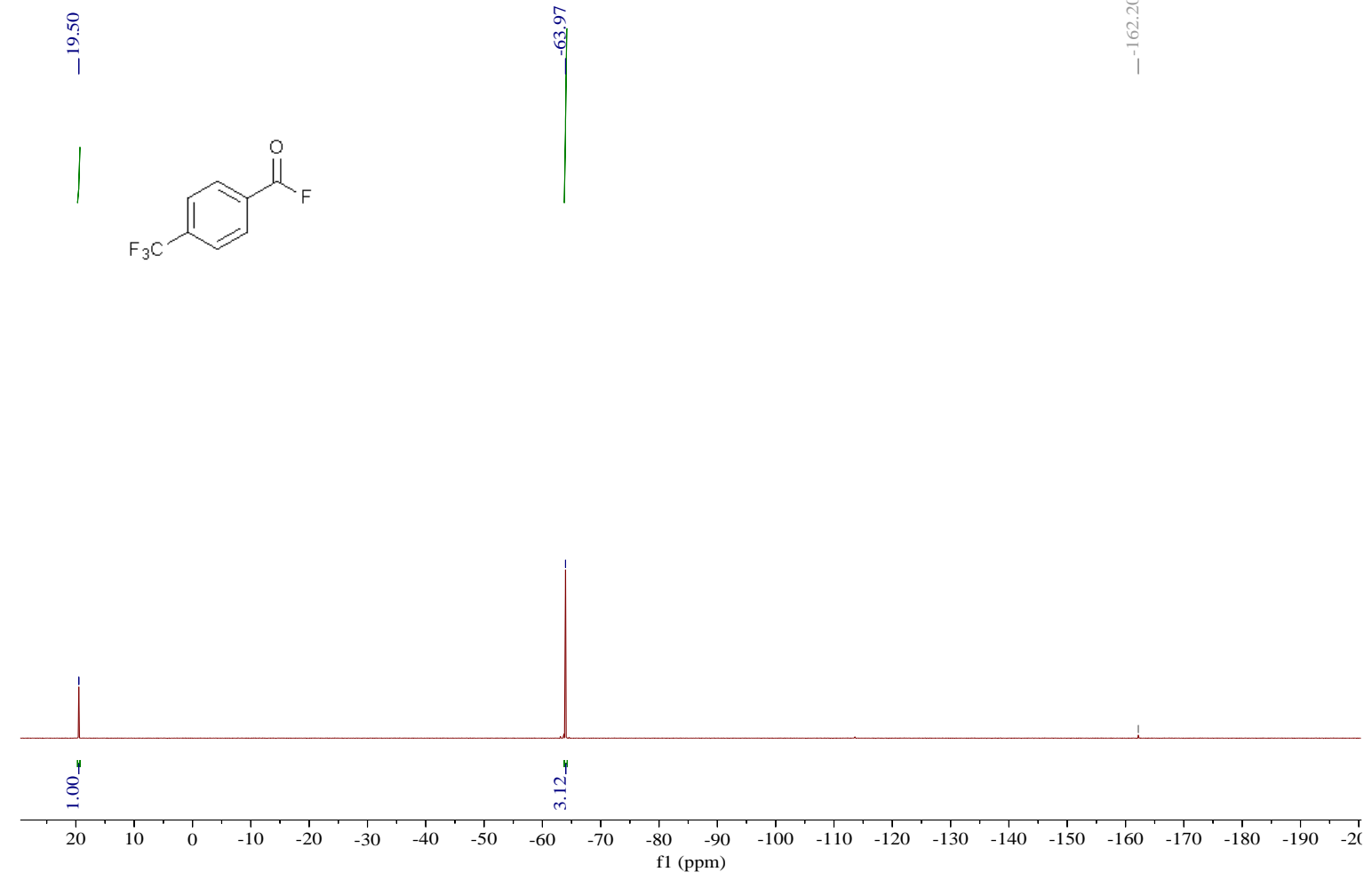
4-Methylbenzoyl fluoride (1g).

${ }^{1}$ H NMR (300 MHz, $\mathrm{CDCl}_{3}$ )
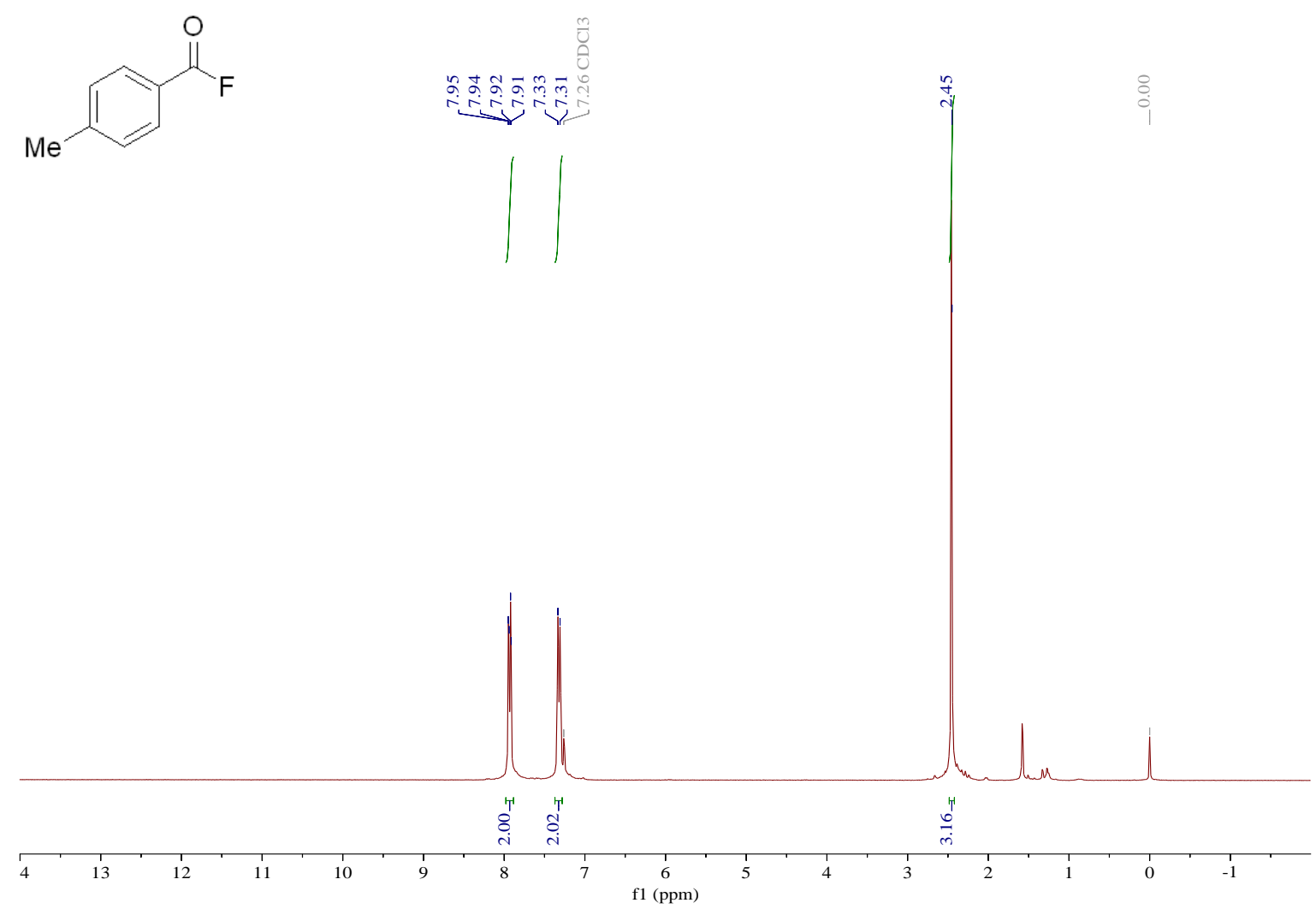

${ }^{19}$ F NMR (282 MHz, $\mathrm{CDCl}_{3}$ )

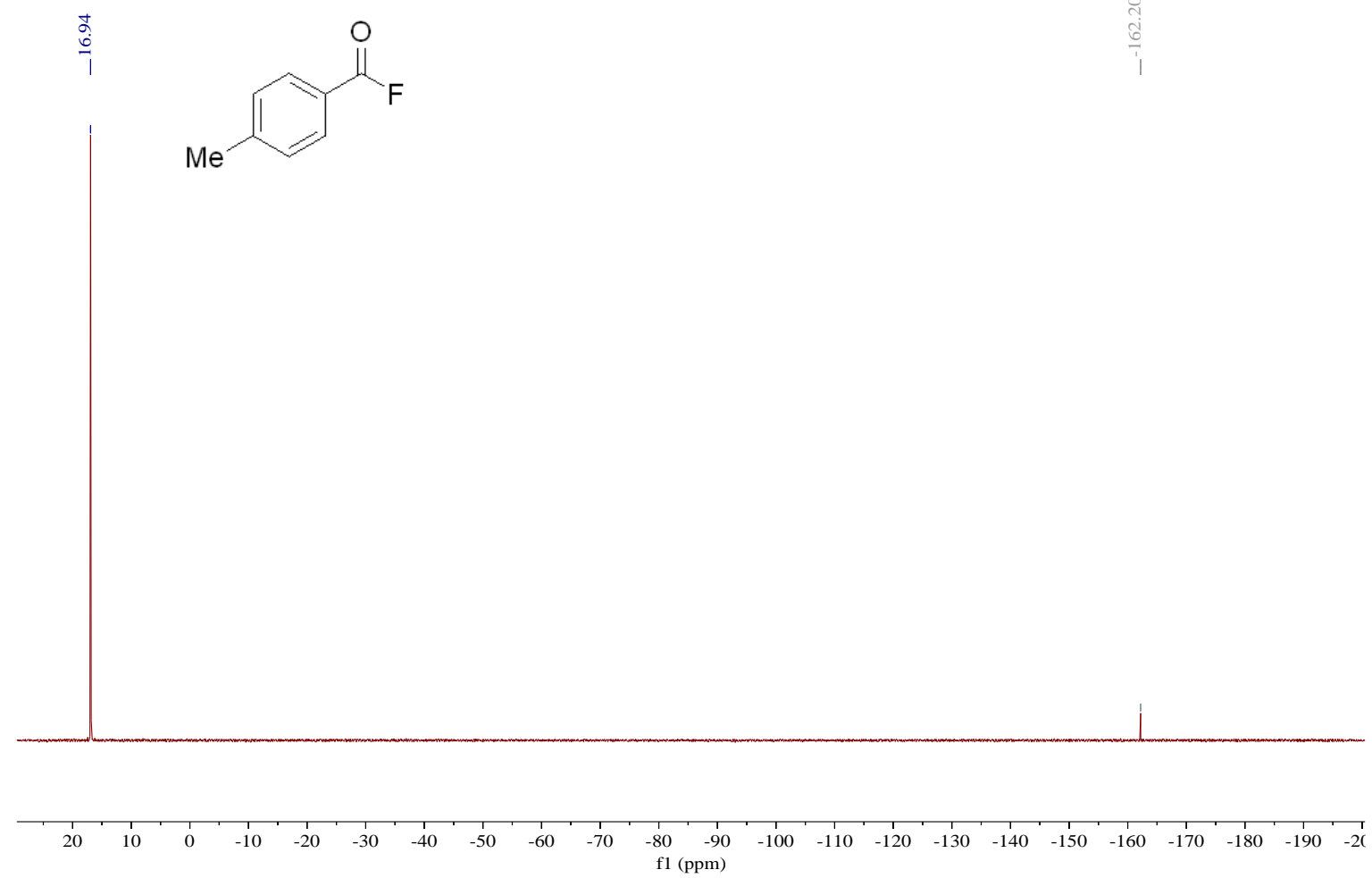


4-Methoxybenzoyl fluoride (1h).

${ }^{1} \mathrm{H}$ NMR (300 MHz, $\left.\mathrm{CDCl}_{3}\right)$

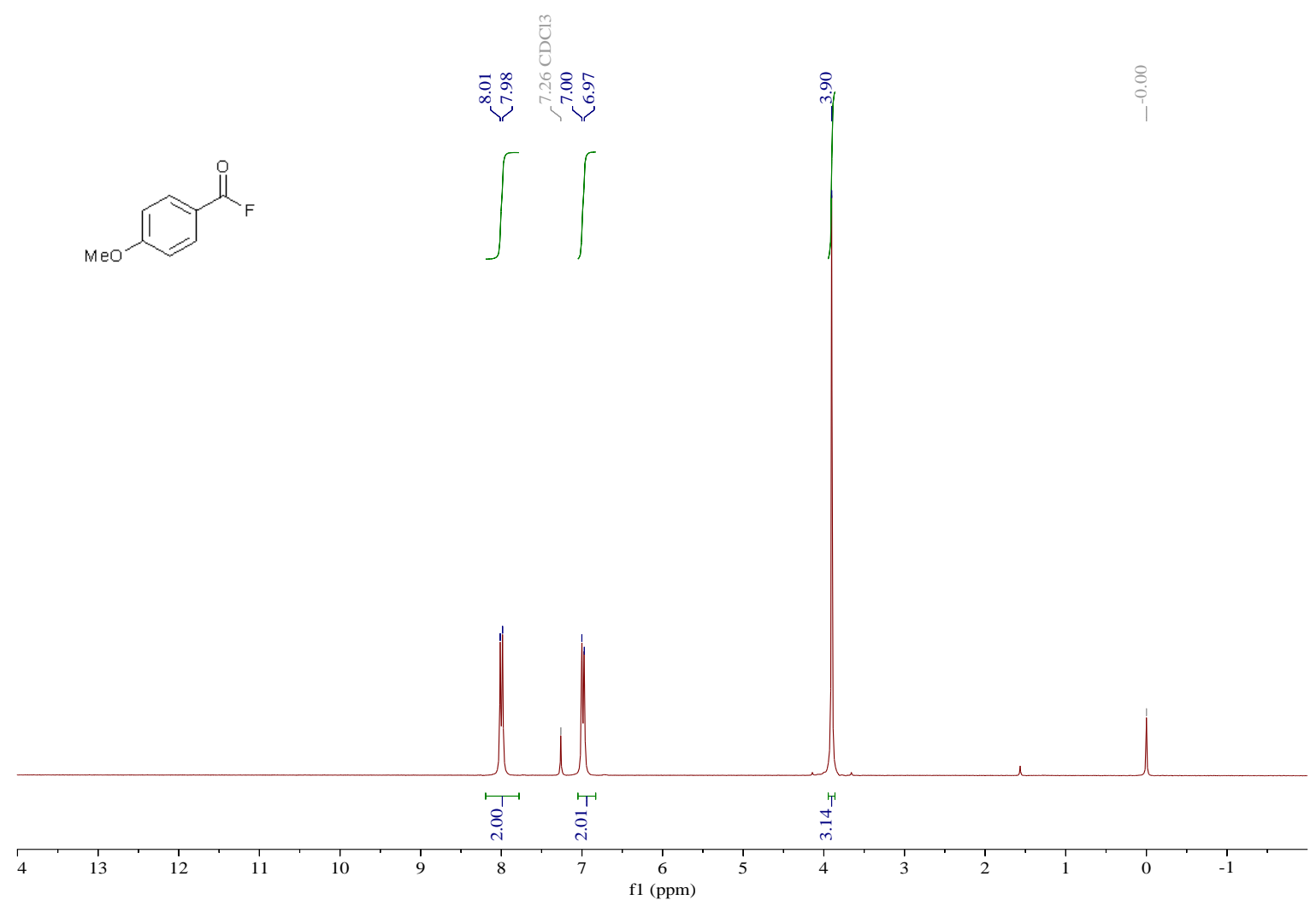

${ }^{19}$ F NMR (282 MHz, $\left.\mathrm{CDCl}_{3}\right)$

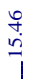<smiles>COc1ccc(C(=O)F)cc1</smiles>

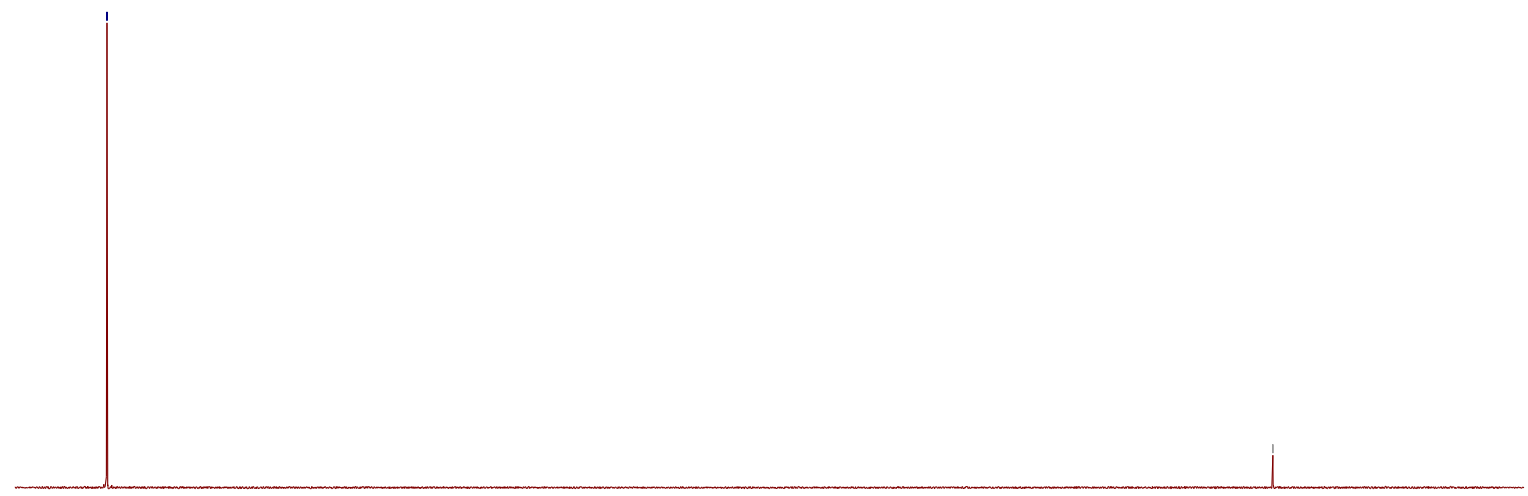


[1,1'-Biphenyl]-4-carbonyl fluoride (1i).

${ }^{1} \mathrm{H}$ NMR (300 MHz, $\left.\mathrm{CDCl}_{3}\right)$

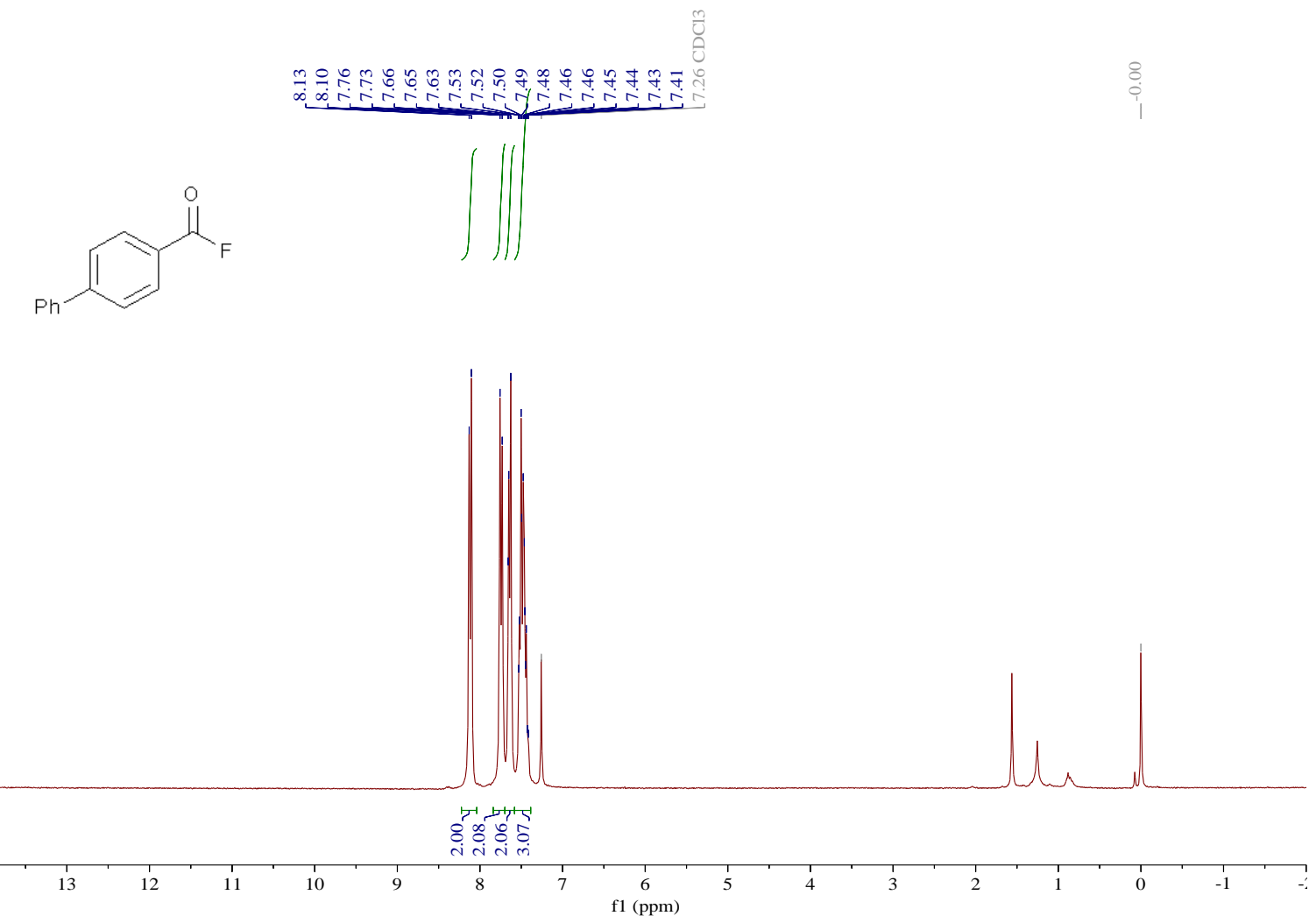

${ }^{19}$ F NMR (282 MHz, $\left.\mathrm{CDCl}_{3}\right)$

$\stackrel{8}{\stackrel{8}{7}}$<smiles>O=C(F)c1ccc(-c2ccccc2)cc1</smiles>

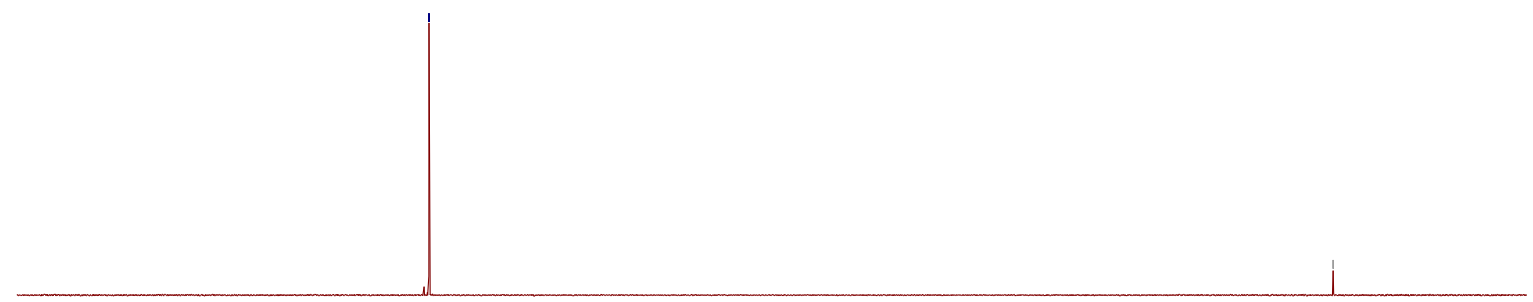

$\begin{array}{rlllllllllllllllllllllllllllllllll}90 & 80 & 70 & 60 & 50 & 40 & 30 & 20 & 10 & 0 & -10 & -20 & -30 & -40 & -50 & -60 & -70 & -80 & -90 & -100 & -110 & -120 & -130 & -140 & -150 & -160 & -170 & -180 & -190 & -2(\end{array}$ 4-(tert-Butyl)benzoyl fluoride (1j). 
${ }^{1} \mathrm{H}$ NMR (300 MHz, $\mathrm{CDCl}_{3}$ )

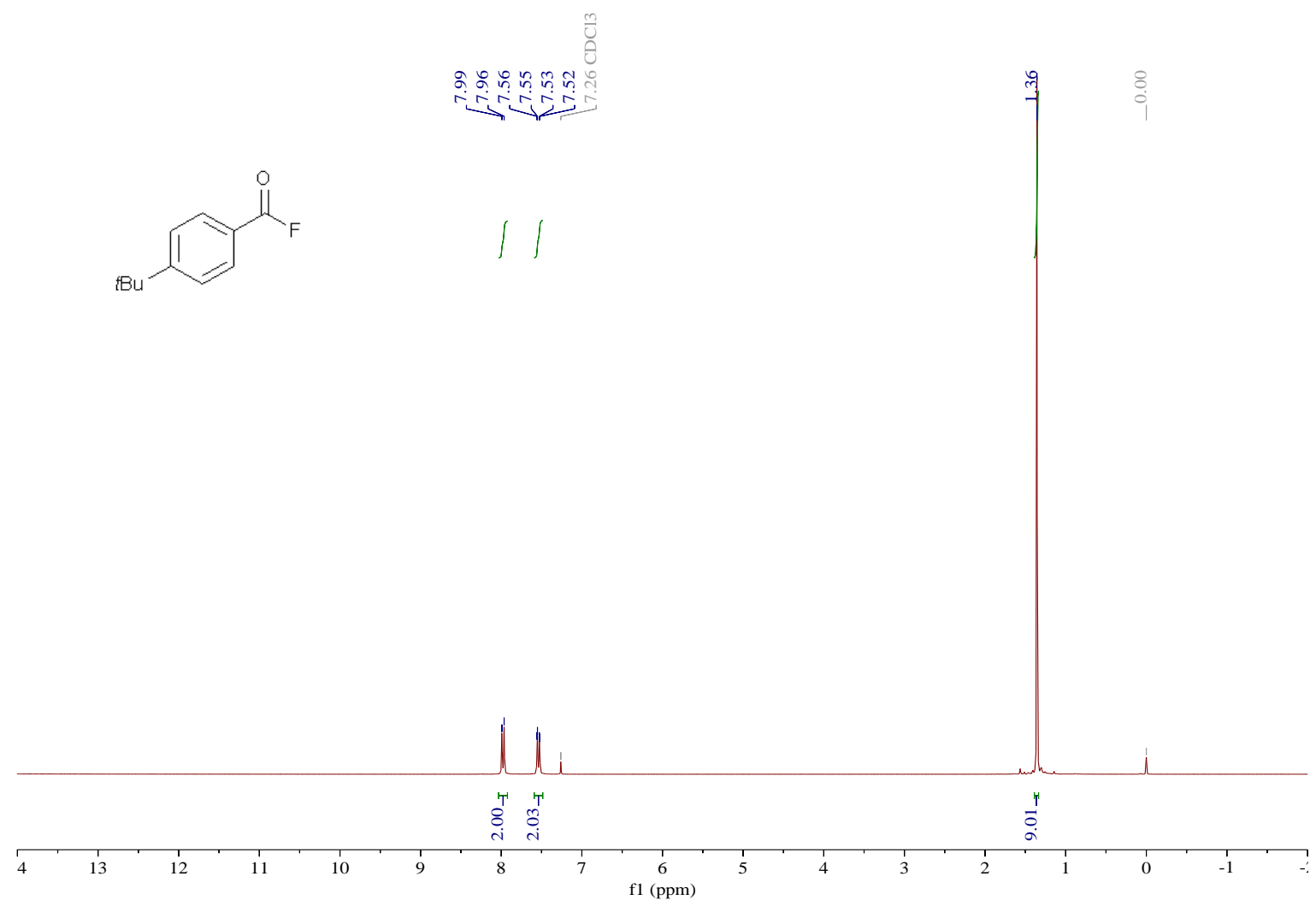

${ }^{19}$ F NMR (282 MHz, $\left.\mathrm{CDCl}_{3}\right)$

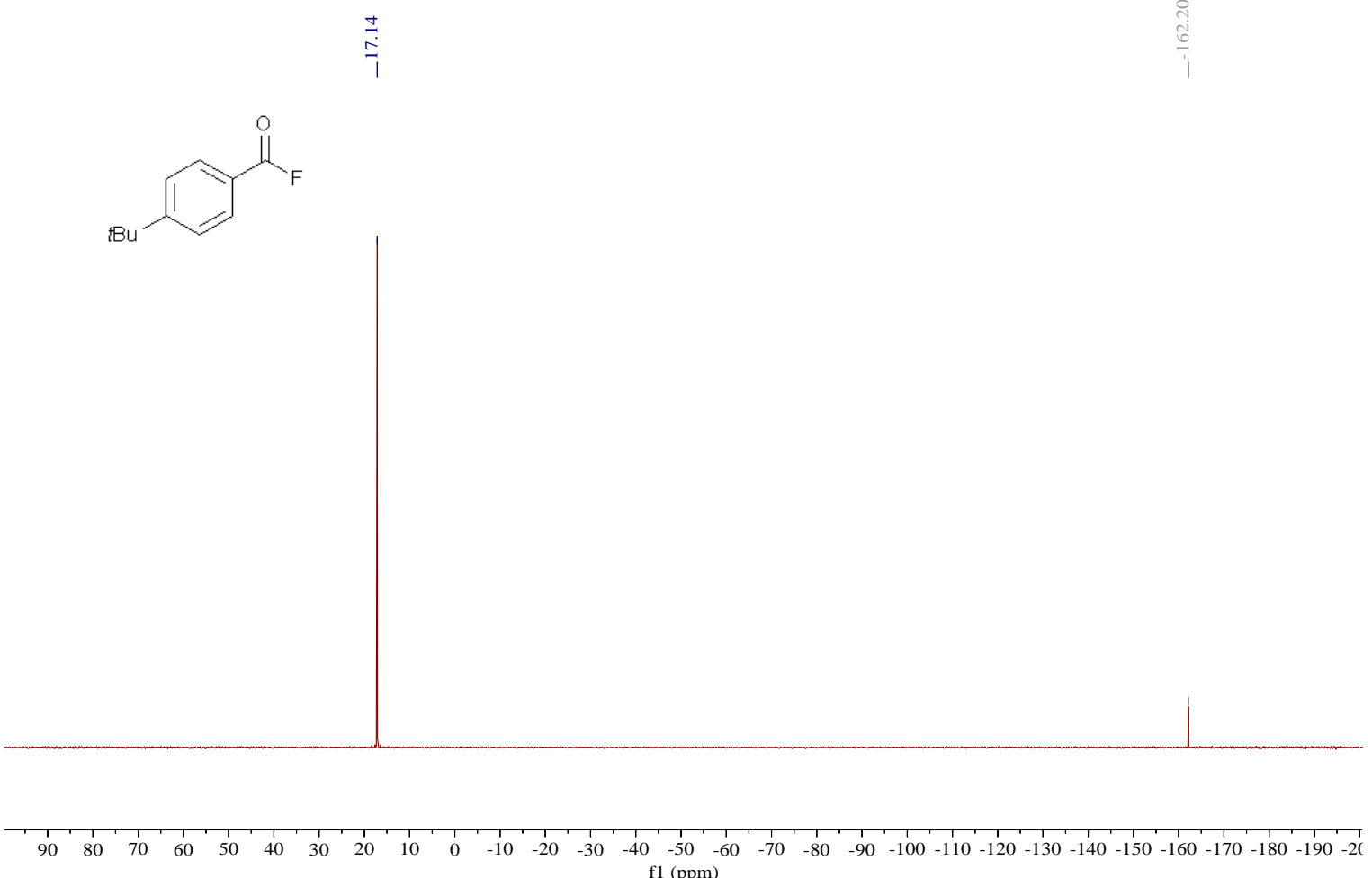


4-Butylbenzoyl fluoride (1k).

${ }^{1} \mathrm{H}$ NMR (300 MHz, $\left.\mathrm{CDCl}_{3}\right)$<smiles>CCCCc1ccc(C(=O)F)cc1</smiles>
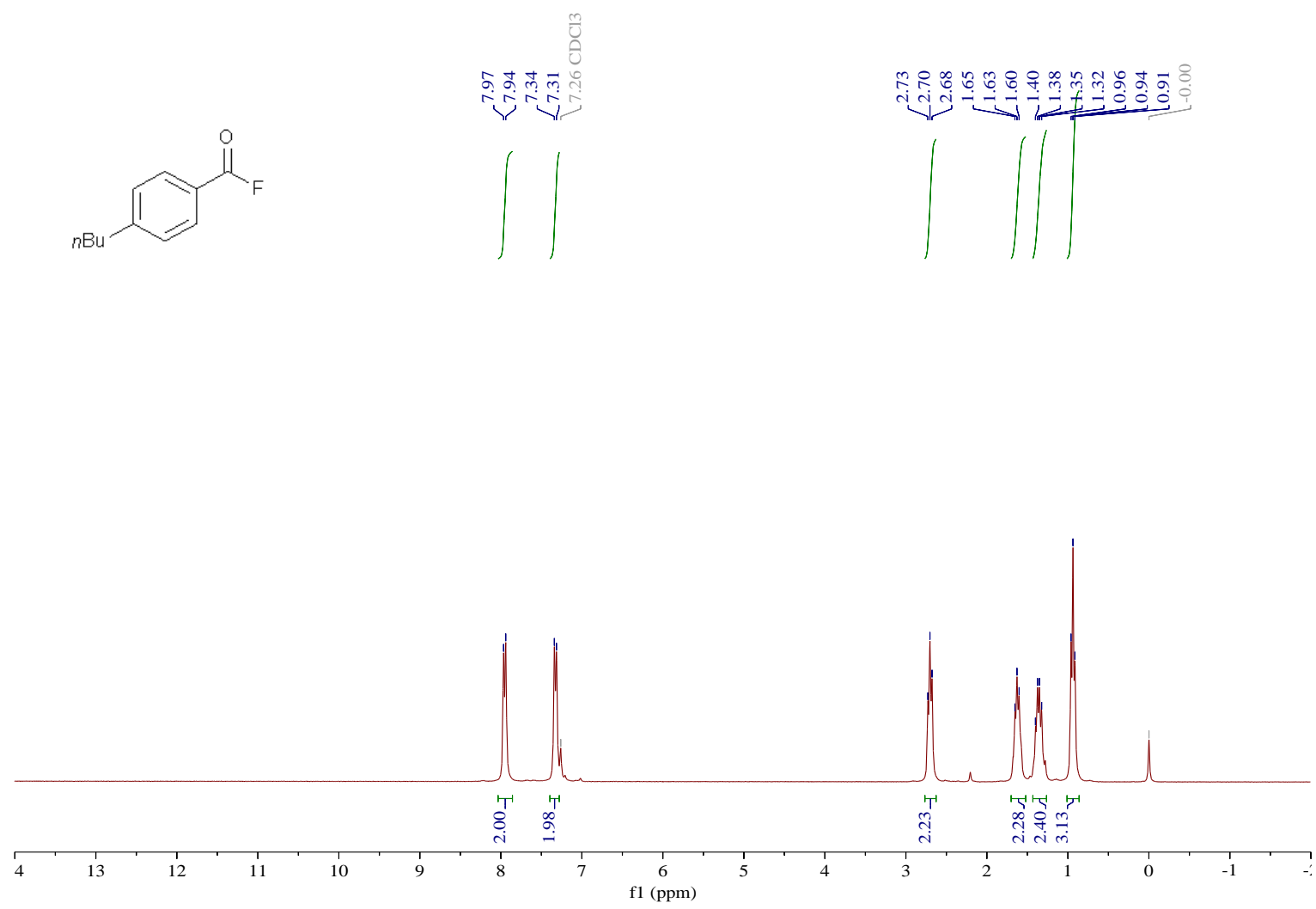

${ }^{19}$ F NMR (282 MHz, $\left.\mathrm{CDCl}_{3}\right)$

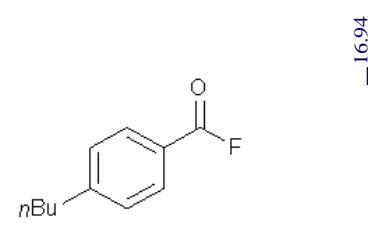

$\begin{array}{llllllllllllllllllllllllllllllllllll}90 & 80 & 70 & 60 & 50 & 40 & 30 & 20 & 10 & 0 & -10 & -20 & -30 & -40 & -50 & -60 & -70 & -80 & -90 & -100 & -110 & -120 & -130 & -140 & -150 & -160 & -170 & -180 & -190 & -2(\end{array}$ 
4-Cyclohexylbenzoyl fluoride (11).

${ }^{1} \mathrm{H}$ NMR (300 MHz, $\mathrm{CDCl}_{3}$ )
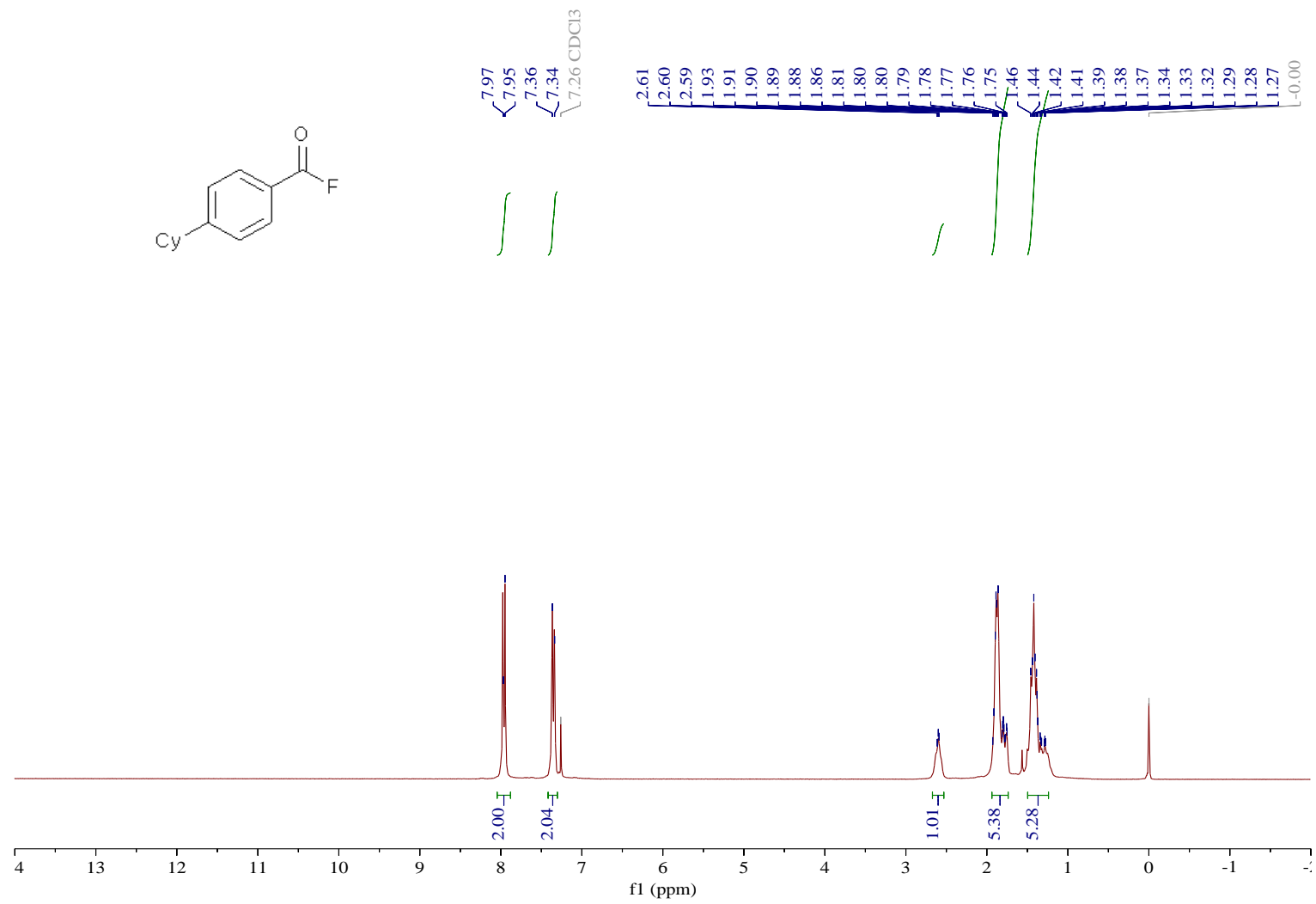

${ }^{19}$ F NMR (282 MHz, CDCl 3 )

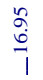<smiles>O=C(F)c1ccc(Cl)cc1</smiles>

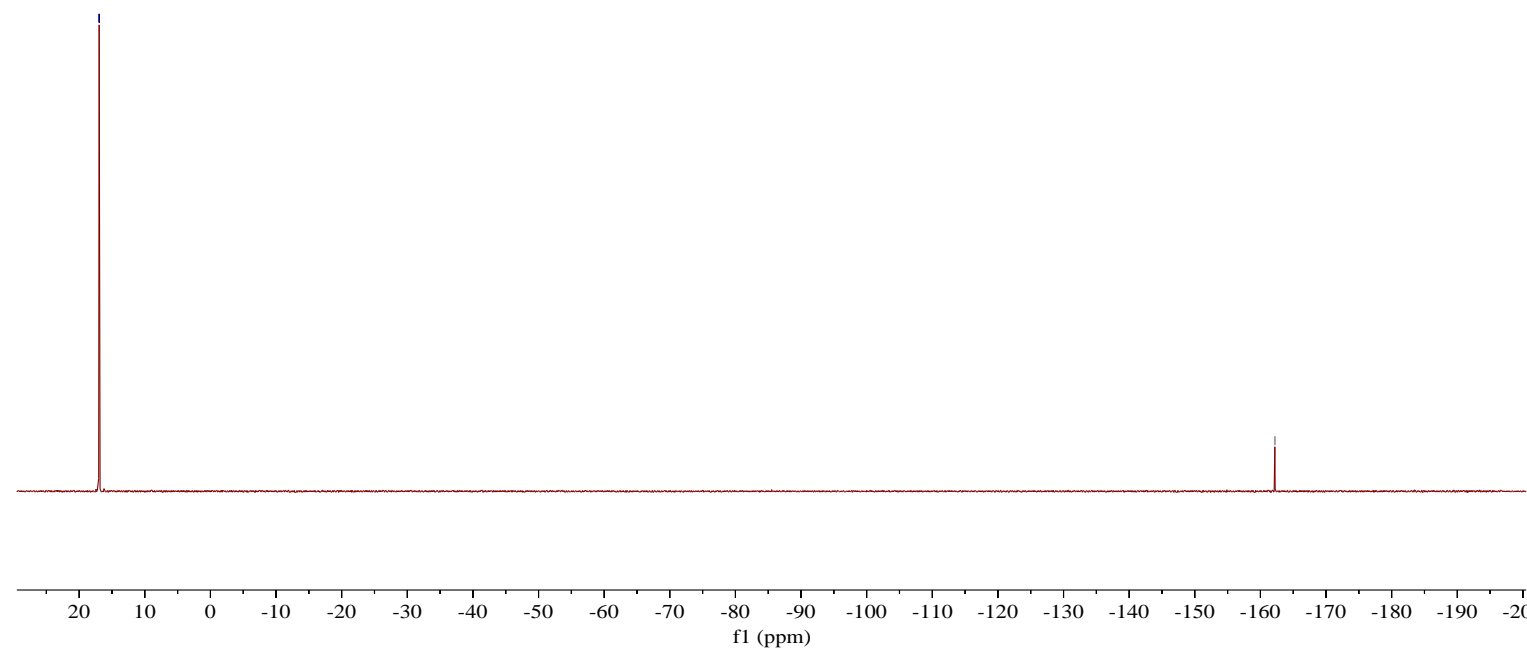


3-Methylbenzoyl fluoride (1m).

${ }^{1} \mathrm{H}$ NMR (300 MHz, $\mathrm{CDCl}_{3}$ )

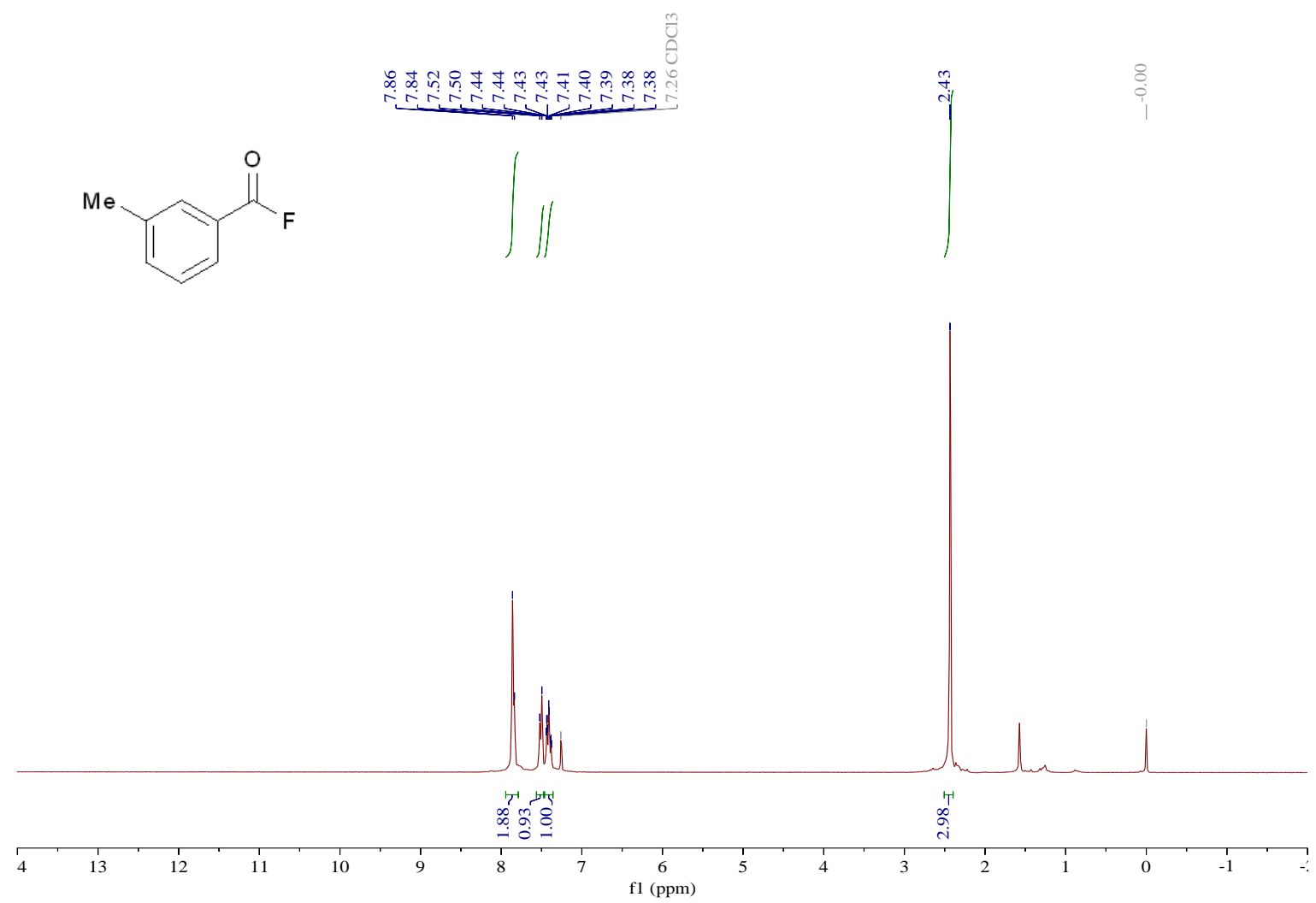

${ }^{19}$ F NMR (282 MHz, $\left.\mathrm{CDCl}_{3}\right)$

$\stackrel{0}{\stackrel{0}{\sim}}$<smiles>Cc1cccc(C(=O)F)c1</smiles>

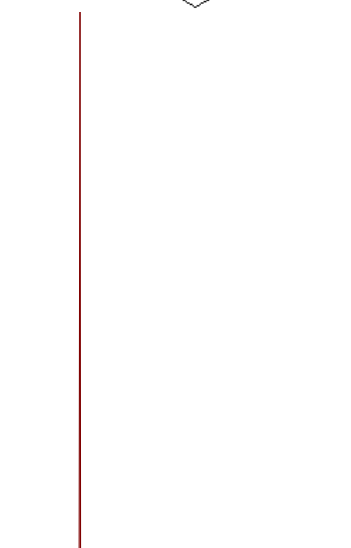
$\begin{array}{ccccccccccccccc}-80 & -90 & -100 & -110 & -120 & -130 & -140 & -150 & -160 & -170 & -180 & -190 & -26 \\ \text { f1 (ppm) }\end{array}$ 
2-Fluorobenzoyl fluoride (1n).

${ }^{1} \mathrm{H}$ NMR (300 MHz, $\left.\mathrm{CDCl}_{3}\right)$

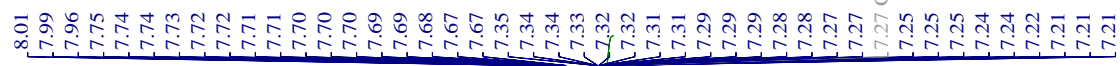<smiles>O=C(F)c1ccccc1F</smiles><smiles>CC1C=CC=C1</smiles>

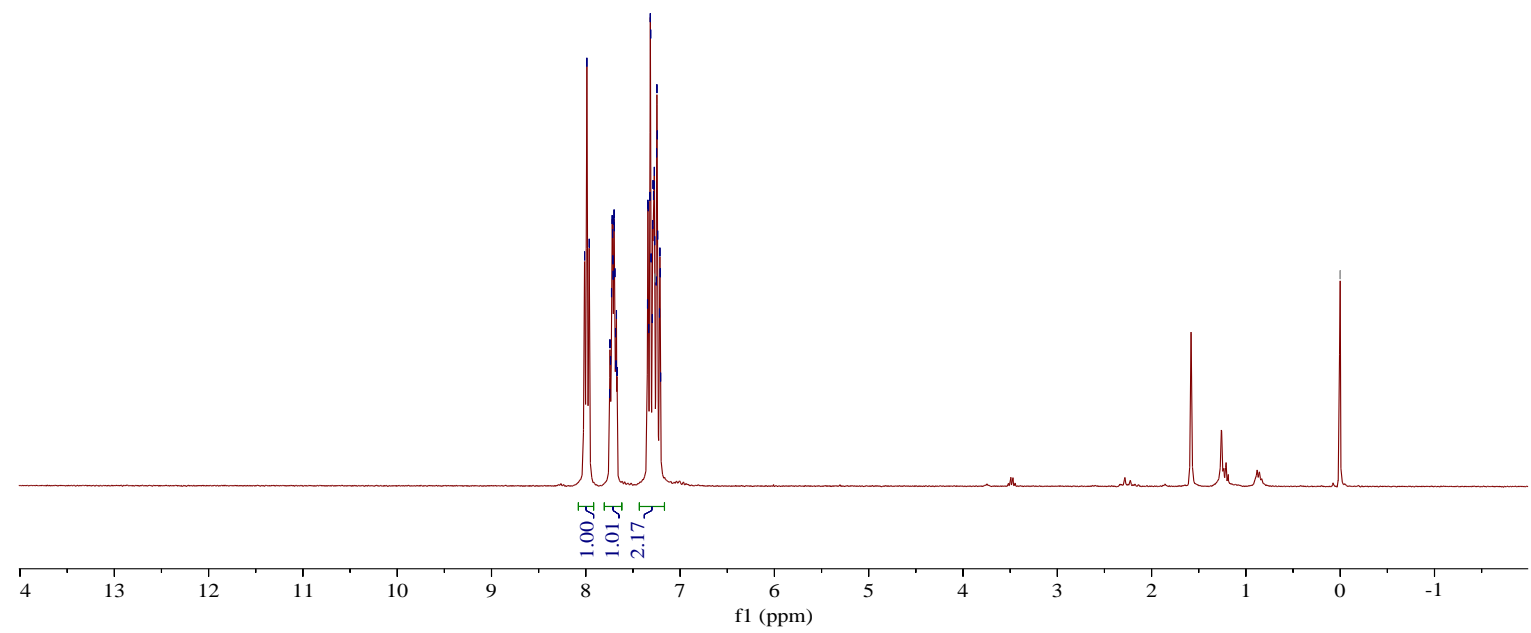

${ }^{19}$ F NMR (282 MHz, $\left.\mathrm{CDCl}_{3}\right)$

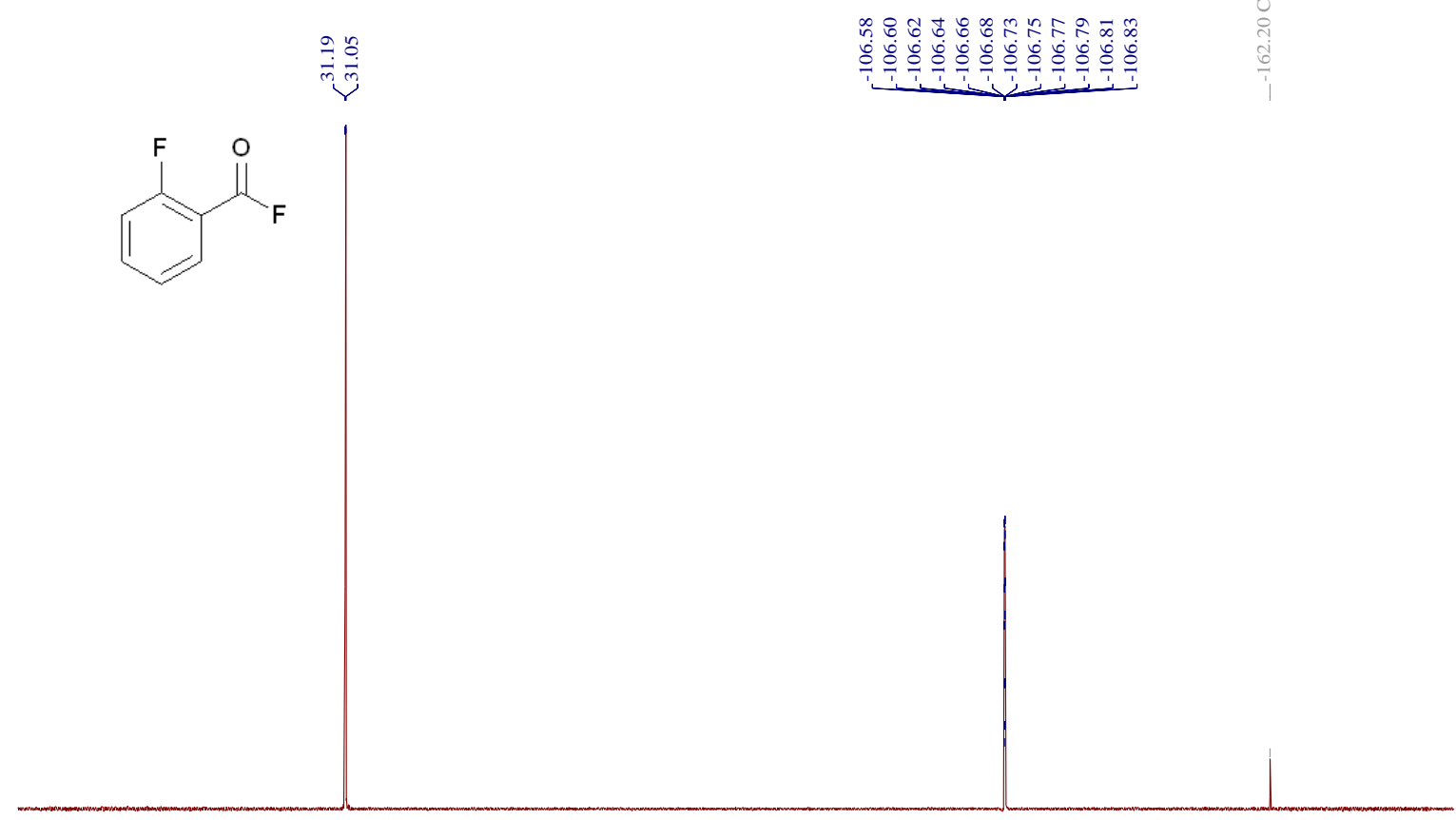

$\begin{array}{llllllllllllllllllllllllllllllllllll}90 & 80 & 70 & 60 & 50 & 40 & 30 & 20 & 10 & 0 & -10 & -20 & -30 & -40 & -50 & -60 & -70 & -80 & -90 & -100 & -110 & -120 & -130 & -140 & -150 & -160 & -170 & -180 & -190 & -2(\end{array}$ 
2-Bromobenzoyl fluoride (10).

${ }^{1} \mathrm{H}$ NMR (300 MHz, $\left.\mathrm{CDCl}_{3}\right)$
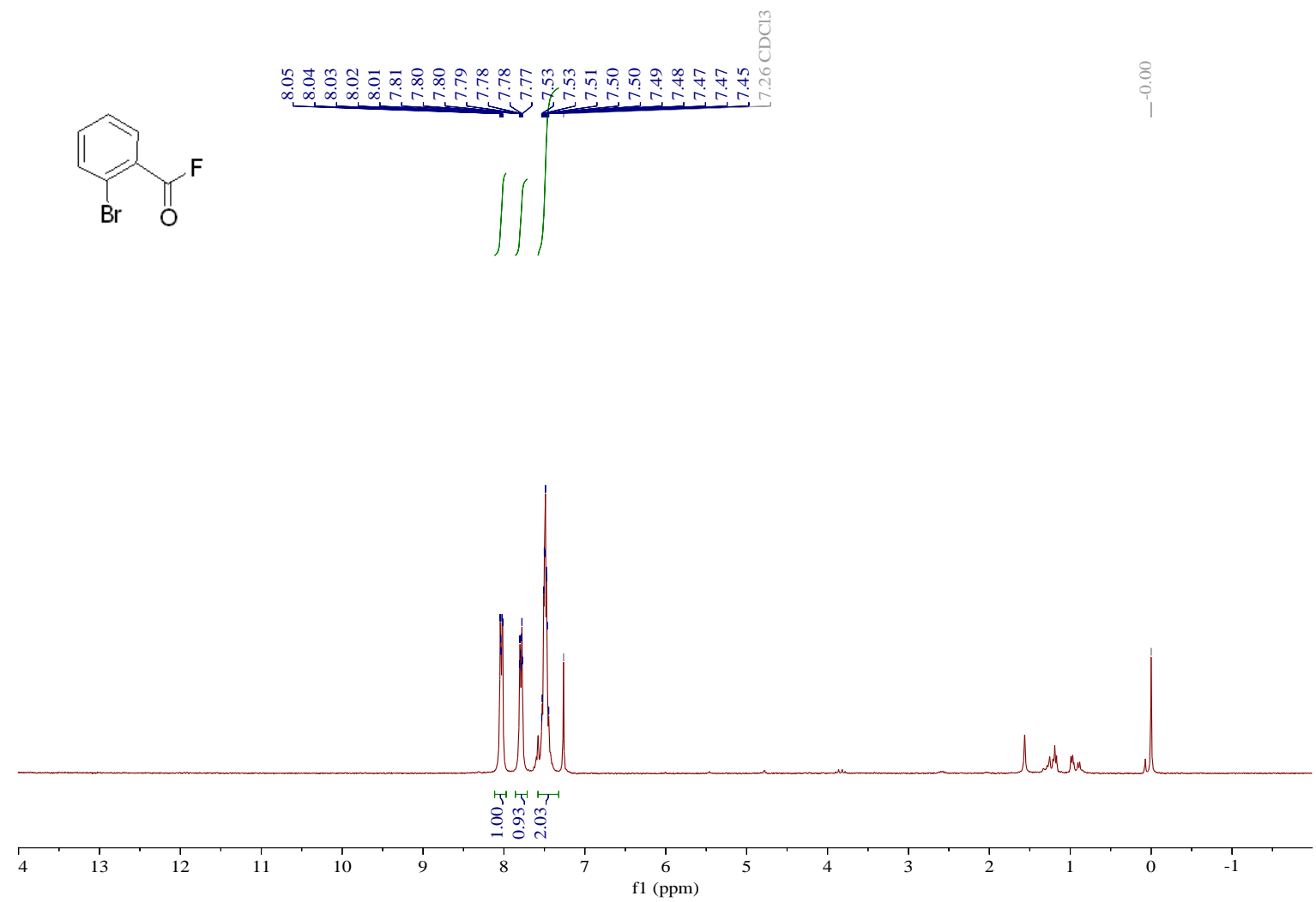

${ }^{13} \mathrm{C}$ NMR (176 MHz, $\left.\mathrm{CDCl}_{3}\right)$<smiles>O=C(F)c1ccccc1Br</smiles>

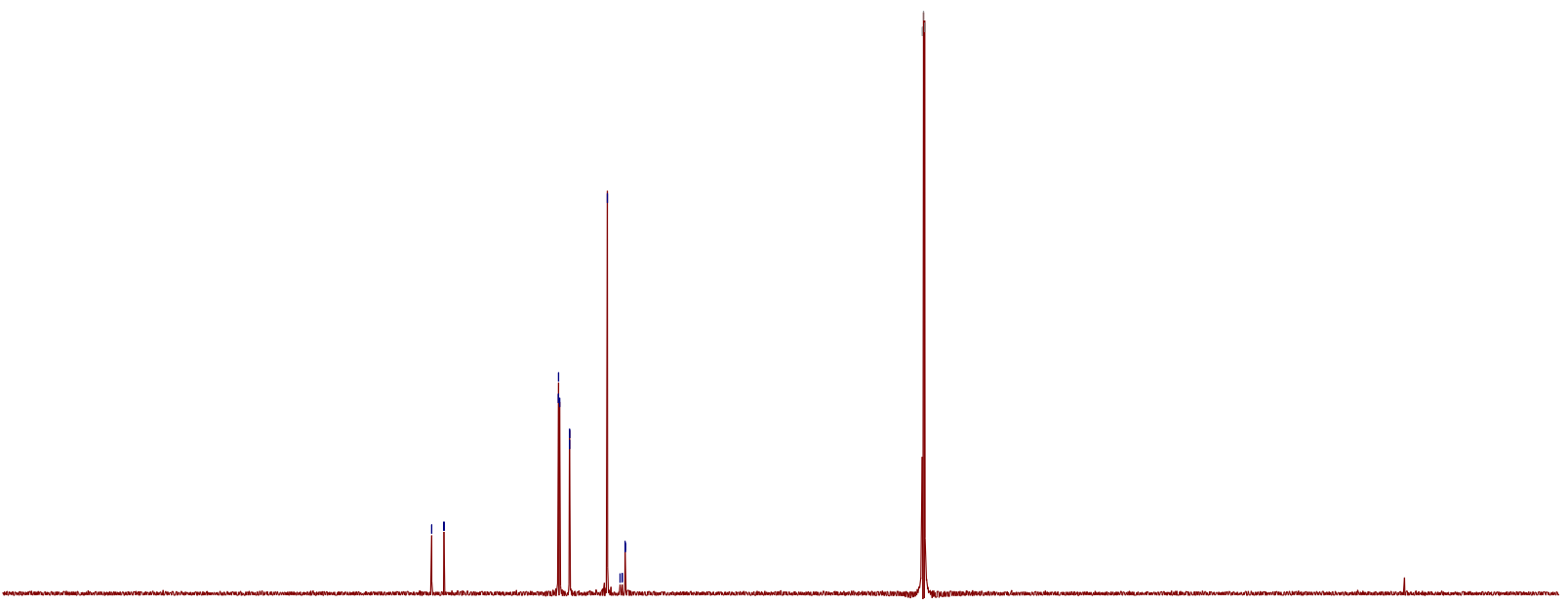

$\begin{array}{lllllllllllllllllllllllll}220 & 210 & 200 & 190 & 180 & 170 & 160 & 150 & 140 & 130 & 120 & 110 & 100 & 90 & 80 & 70 & 60 & 50 & 40 & 30 & 20 & 10 & 0 & -10 & -20\end{array}$ 
${ }^{19}$ F NMR (282 MHz, $\left.\mathrm{CDCl}_{3}\right)$<smiles>O=C(F)c1ccccc1Br</smiles>

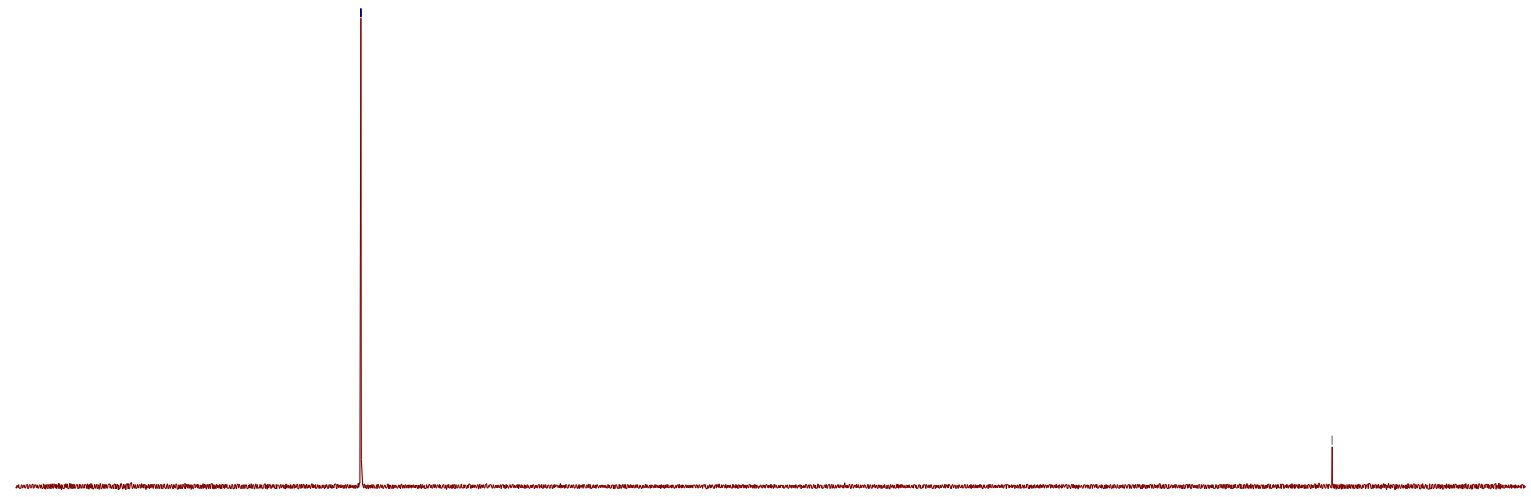

$\begin{array}{llllllllllllllllllllllllllllllllllll}10 & 80 & 70 & 60 & 50 & 40 & 30 & 20 & 10 & 0 & -10 & -20 & -30 & -40 & -50 & -60 & -70 & -80 & -90 & -100 & -110 & -120 & -130 & -140 & -150 & -160 & -170 & -180 & -190 & -2(\end{array}$

[1,1'-Biphenyl]-2-carbonyl fluoride (1p).

${ }^{1} \mathrm{H}$ NMR (300 MHz, $\left.\mathrm{CDCl}_{3}\right)$
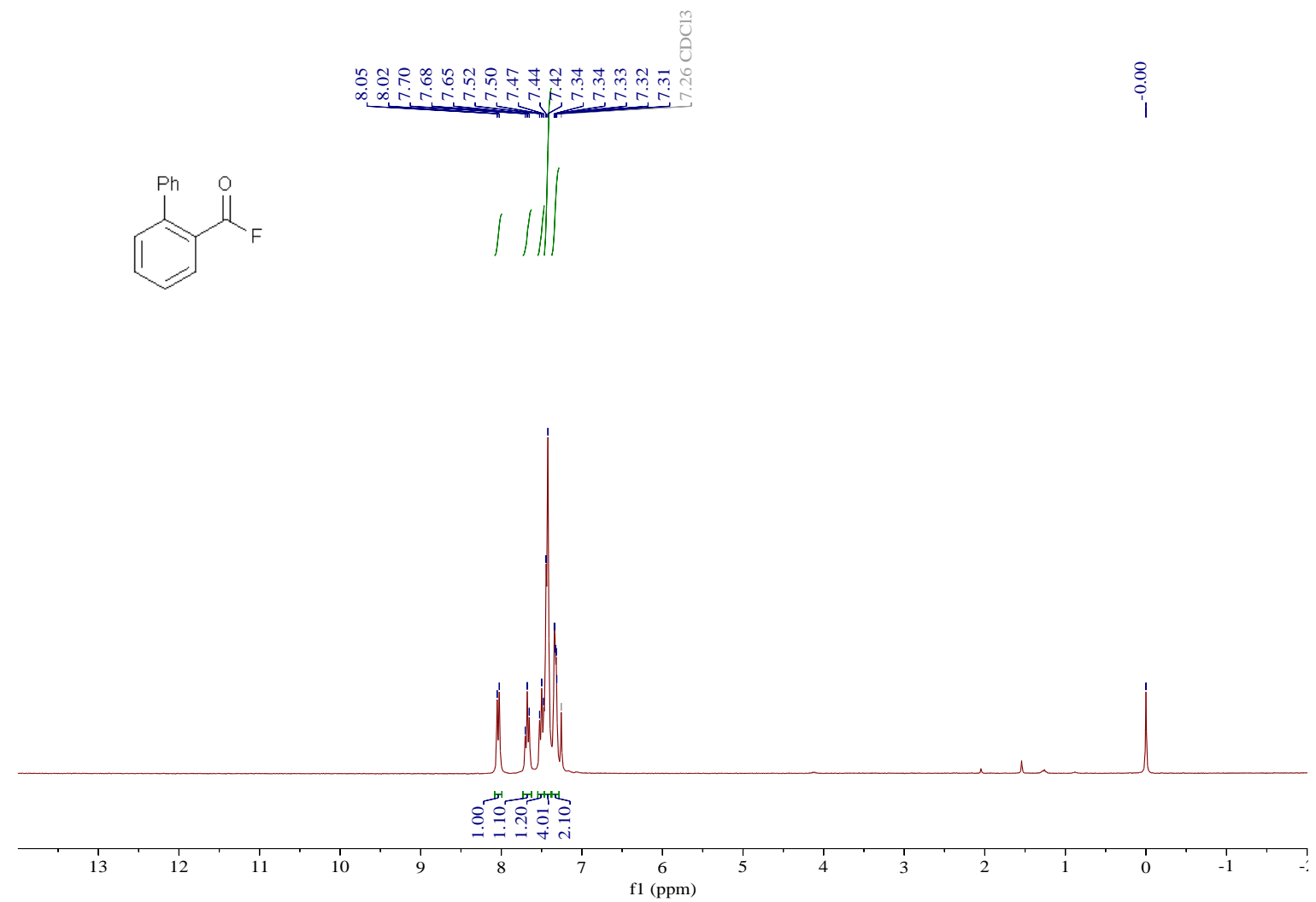
${ }^{19}$ F NMR (282 MHz, $\left.\mathrm{CDCl}_{3}\right)$<smiles>O=C(F)c1ccccc1P</smiles>

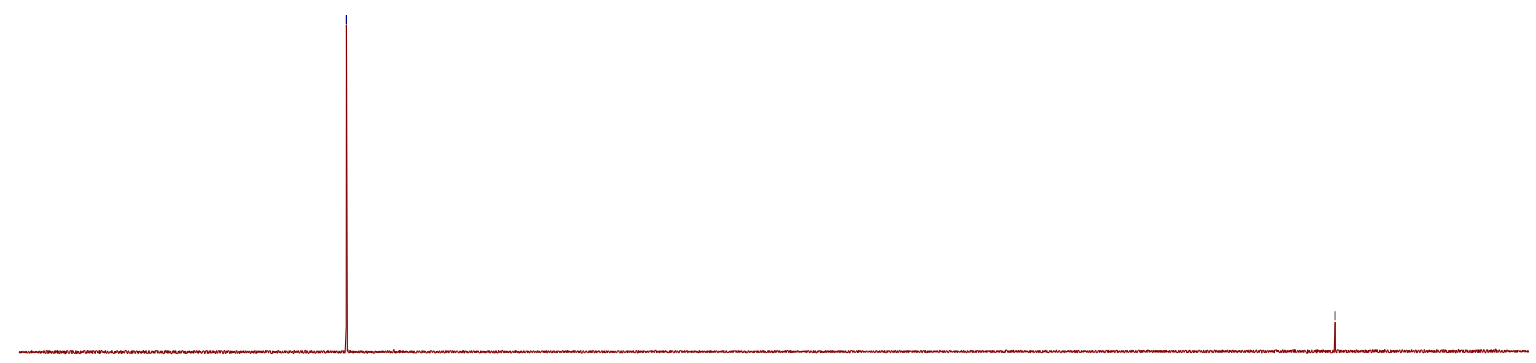

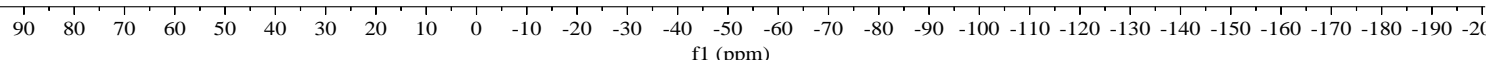

2-Naphthoyl fluoride (1q).

${ }^{1} \mathrm{H}$ NMR (300 MHz, $\left.\mathrm{CDCl}_{3}\right)$

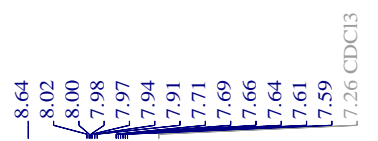

$\overbrace{F}^{\circ}$

$\iint$

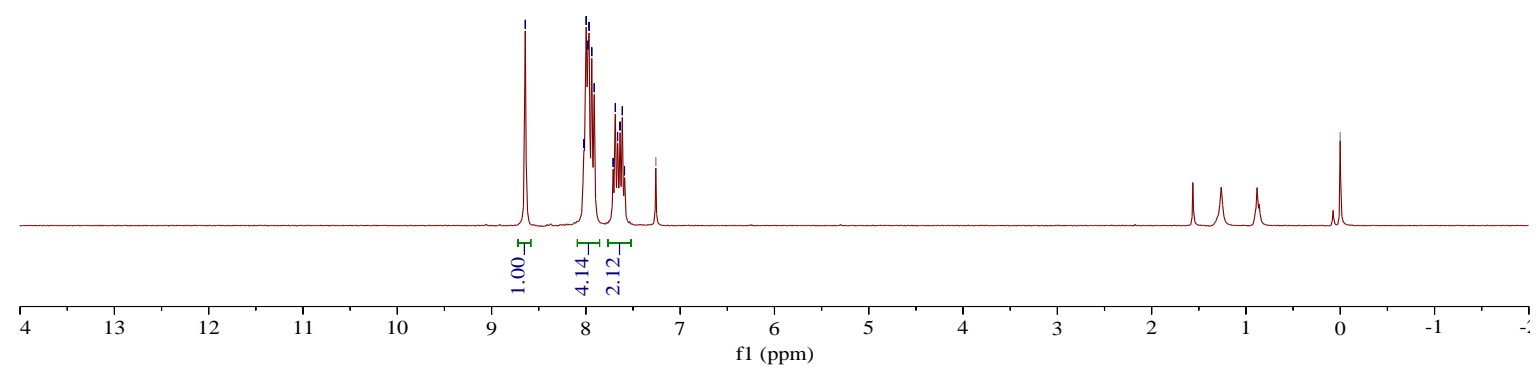


${ }^{19}$ F NMR (282 MHz, $\left.\mathrm{CDCl}_{3}\right)$

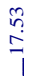<smiles>O=C(F)c1ccc2ccccc2c1</smiles>

|

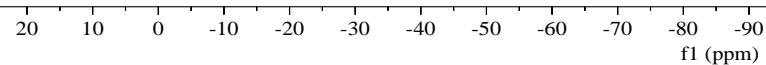

1-Naphthoyl fluoride (1r).

${ }^{1} \mathrm{H}$ NMR (300 MHz, $\mathrm{CDCl}_{3}$ )
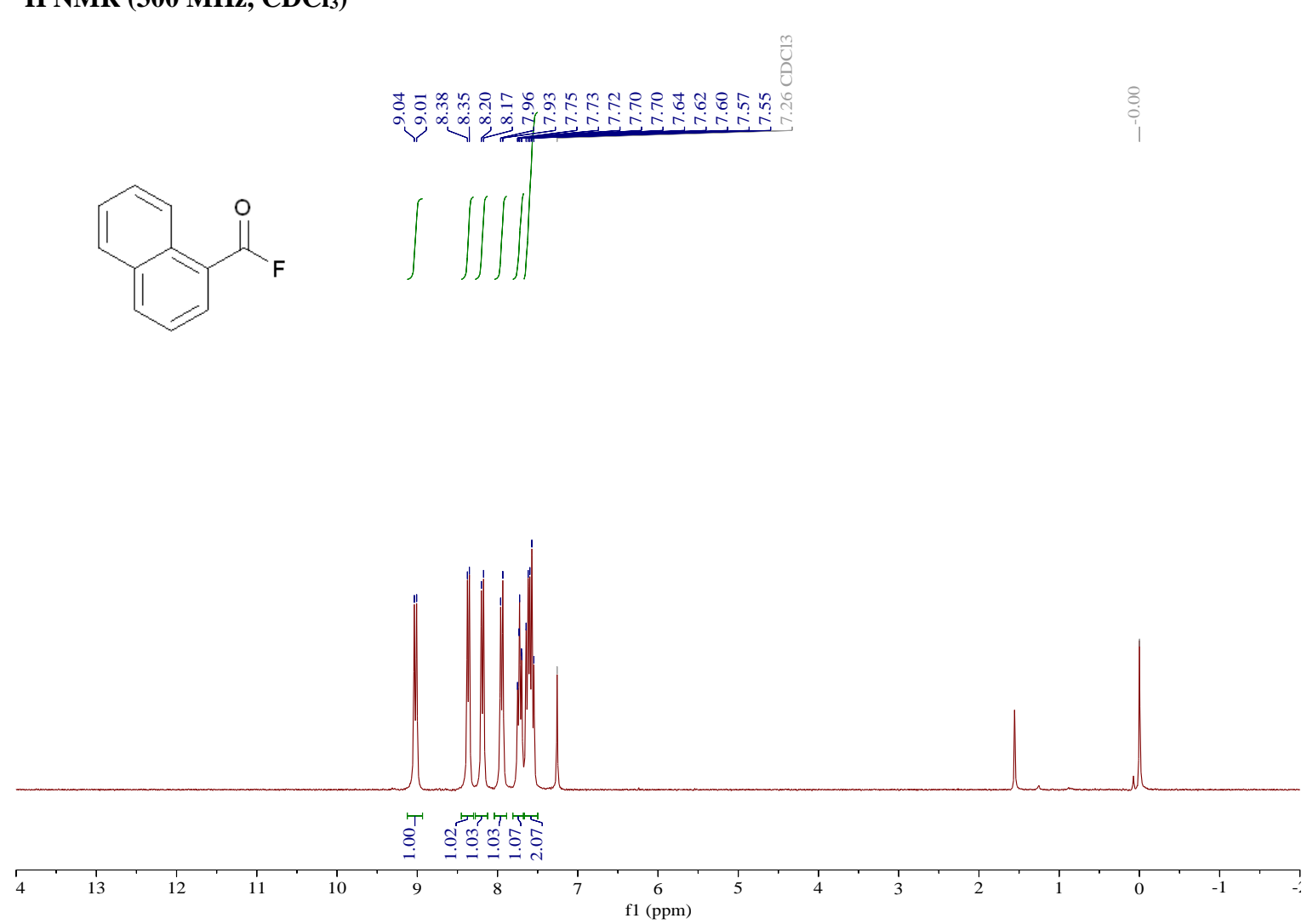
${ }^{19}$ F NMR (282 MHz, $\left.\mathrm{CDCl}_{3}\right)$

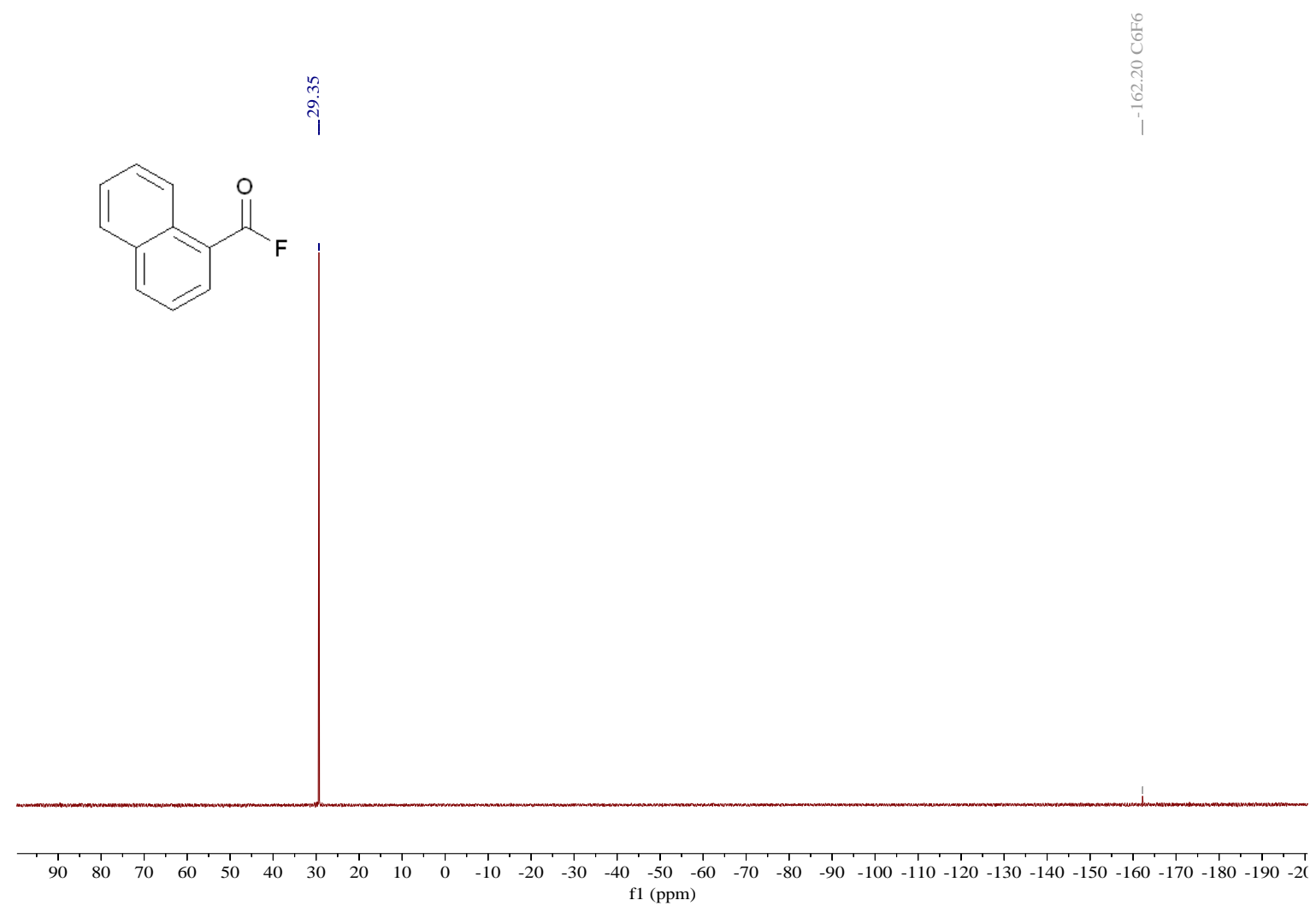

3,5-Dichlorobenzoyl fluoride (1s).

\section{${ }^{1} \mathrm{H}$ NMR (300 MHz, $\mathrm{CDCl}_{3}$ )}<smiles>O=C(F)c1cc(Cl)cc(Cl)c1</smiles>
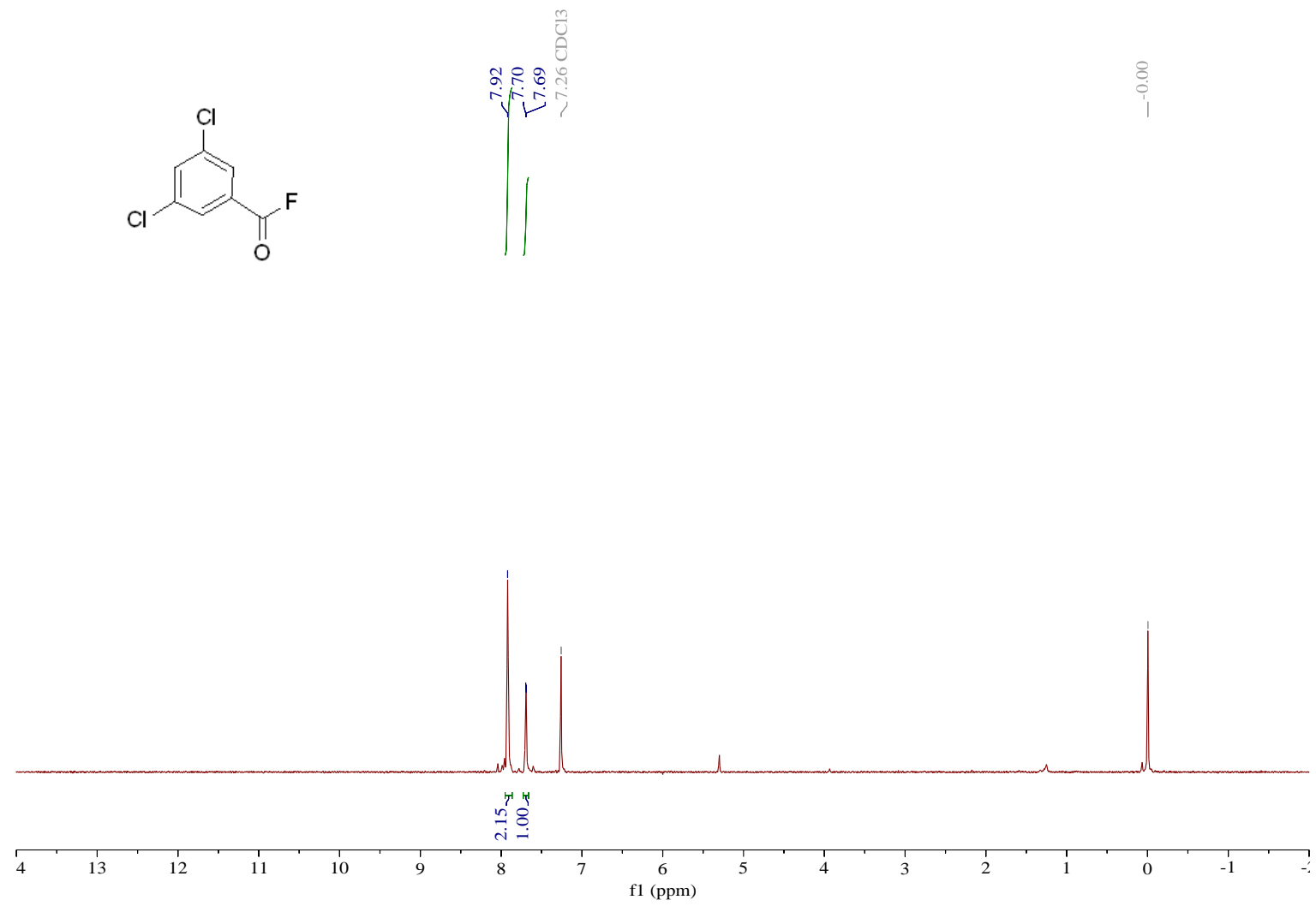
${ }^{19}$ F NMR (282 MHz, $\left.\mathrm{CDCl}_{3}\right)$<smiles>O=C(F)c1cc(Cl)cc(Cl)c1</smiles>

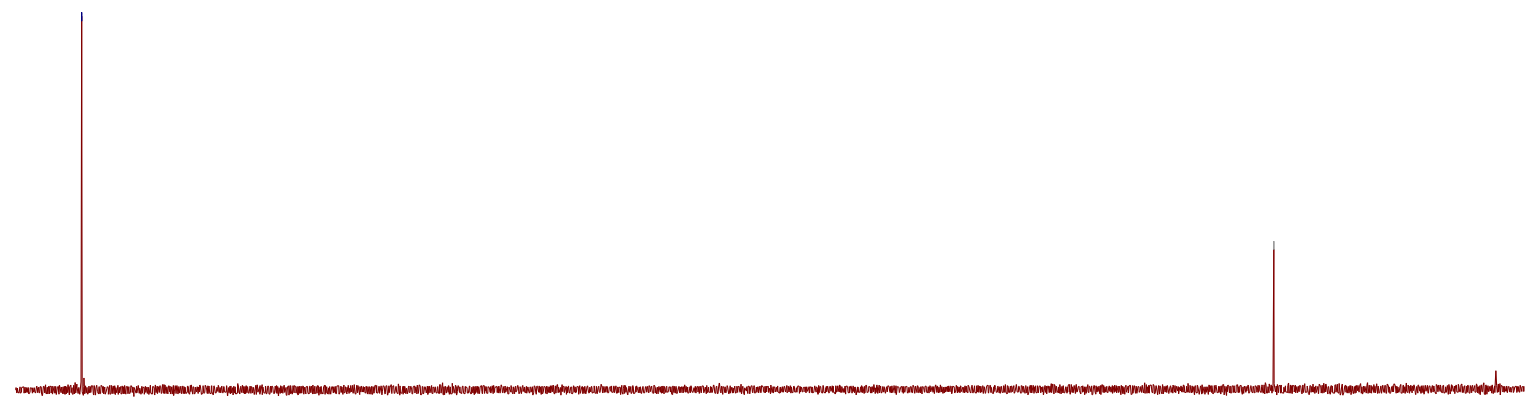

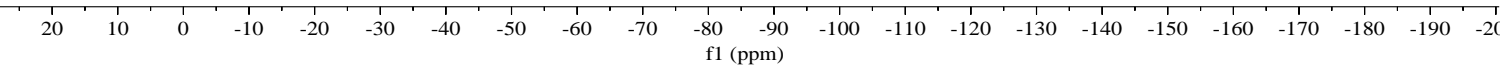

Thiophene-2-carbonyl fluoride (1t).

${ }^{1} \mathrm{H}$ NMR (300 MHz, $\left.\mathrm{CDCl}_{3}\right)$
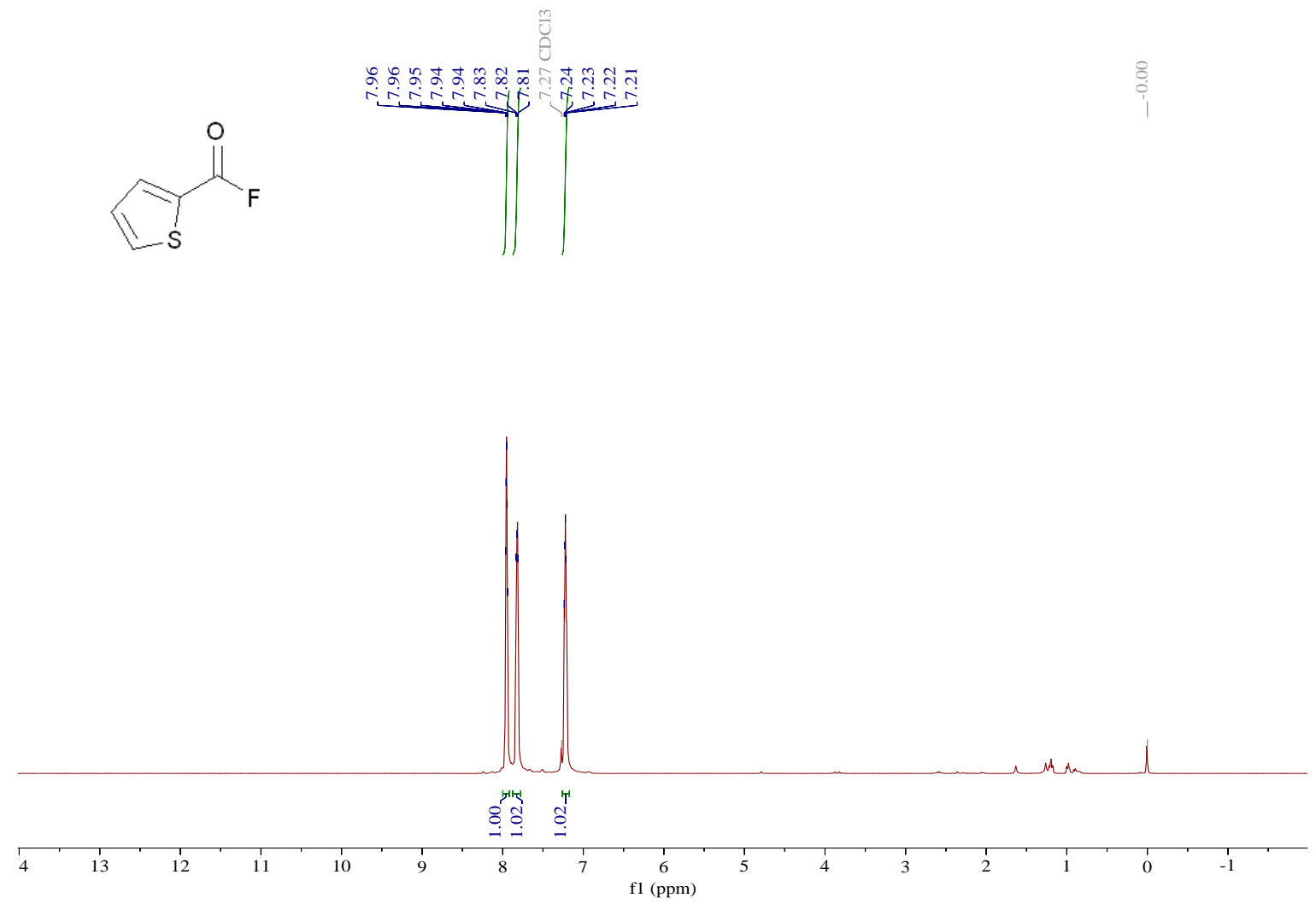
${ }^{19}$ F NMR (282 MHz, $\left.\mathrm{CDCl}_{3}\right)$
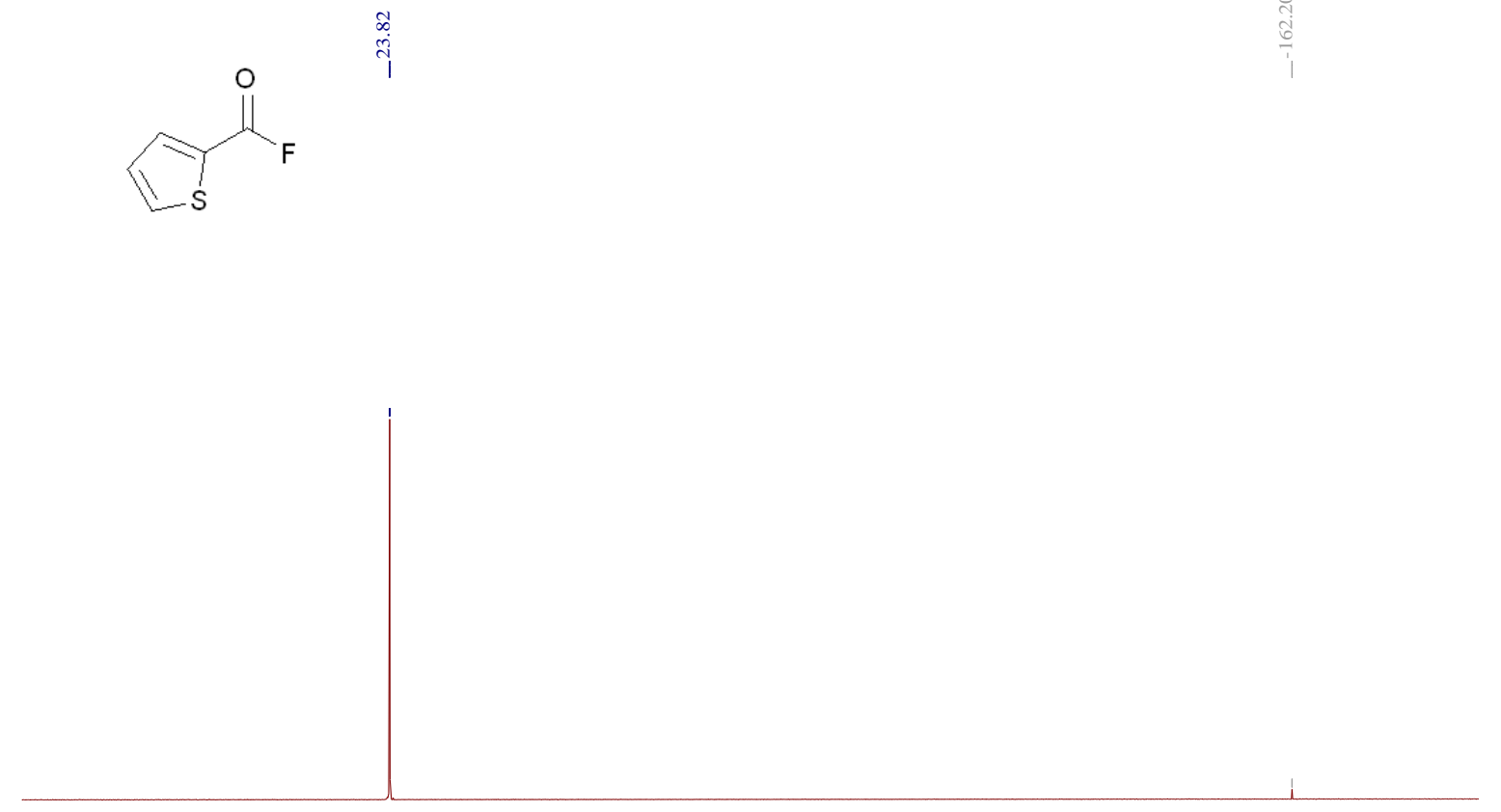

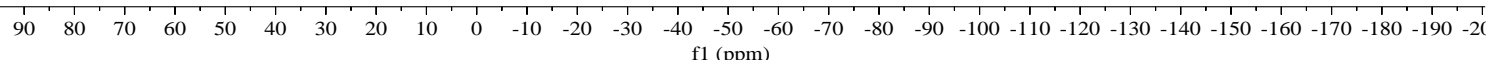

3-Bromothiophene-2-carbonyl fluoride (1u).

${ }^{1} \mathrm{H}$ NMR (300 MHz, $\left.\mathrm{CDCl}_{3}\right)$
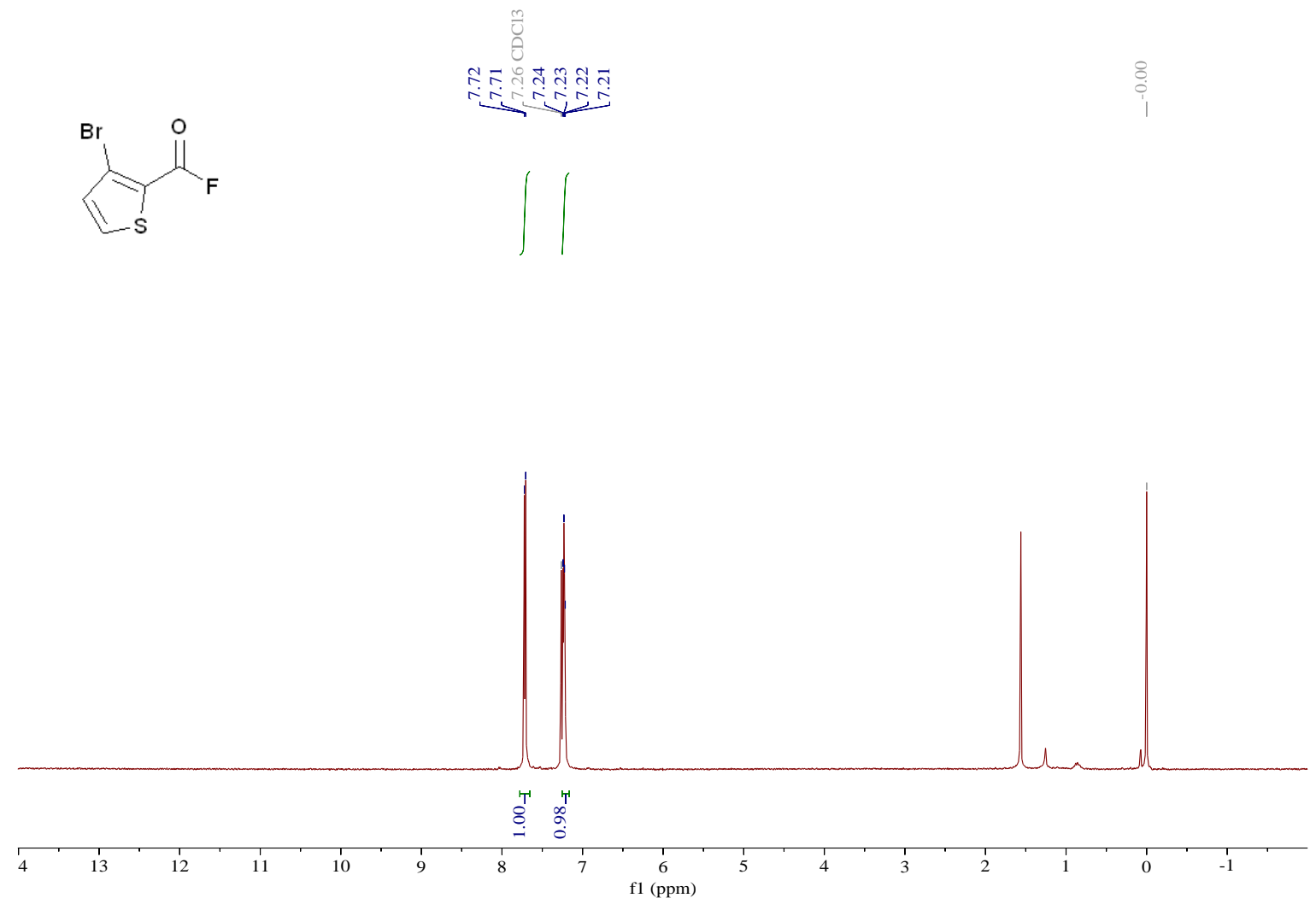
${ }^{19}$ F NMR (282 MHz, $\left.\mathrm{CDCl}_{3}\right)$

$\vec{b}$
ñ
1

กิ<smiles>O=C(F)c1sccc1Br</smiles>

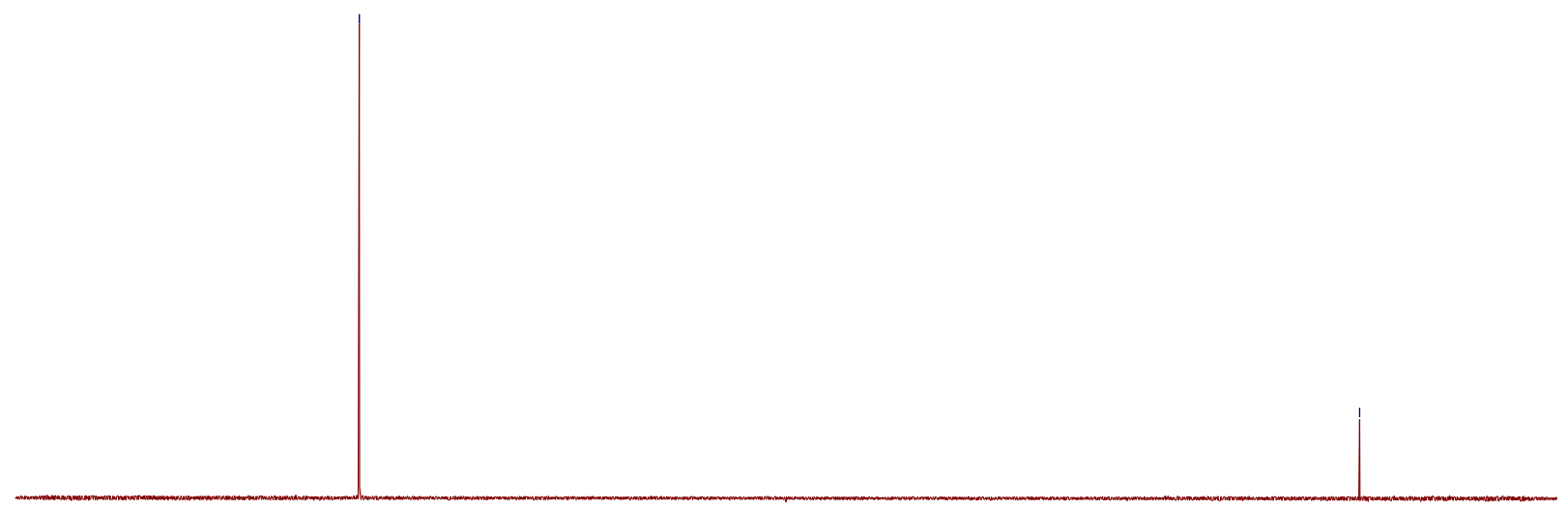

$\begin{array}{lllllllllllllllllllllllllllllllll}90 & 80 & 70 & 60 & 50 & 40 & 30 & 20 & 10 & 0 & -10 & -20 & -30 & -40 & -50 & -60 & -70 & -80 & -90 & -100 & -110 & -120 & -130 & -140 & -150 & -160 & -170 & -180 & -190 & -2(2)\end{array}$ f1 (ppm)

Dodecanoyl fluoride (1v).

${ }^{1} \mathrm{H}$ NMR (300 MHz, $\left.\mathrm{CDCl}_{3}\right)$<smiles>CC(C)(C)CC(=O)F</smiles>
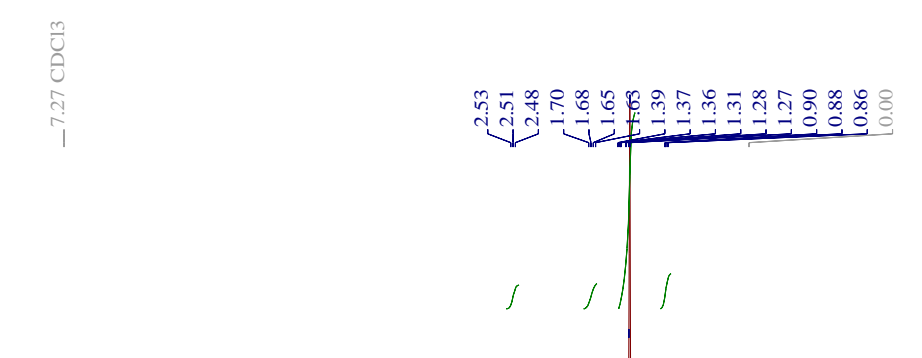

Th

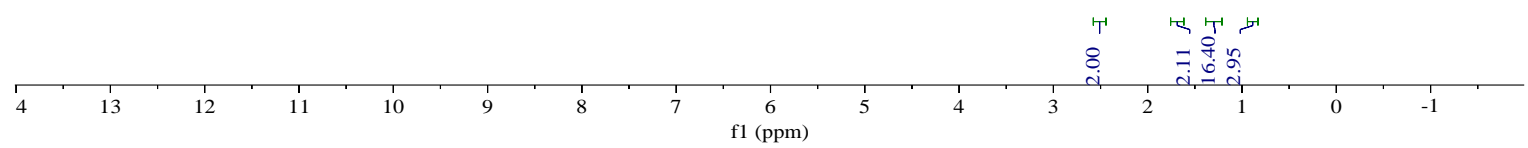


${ }^{19}$ F NMR (282 MHz, $\mathrm{CDCl}_{3}$ )

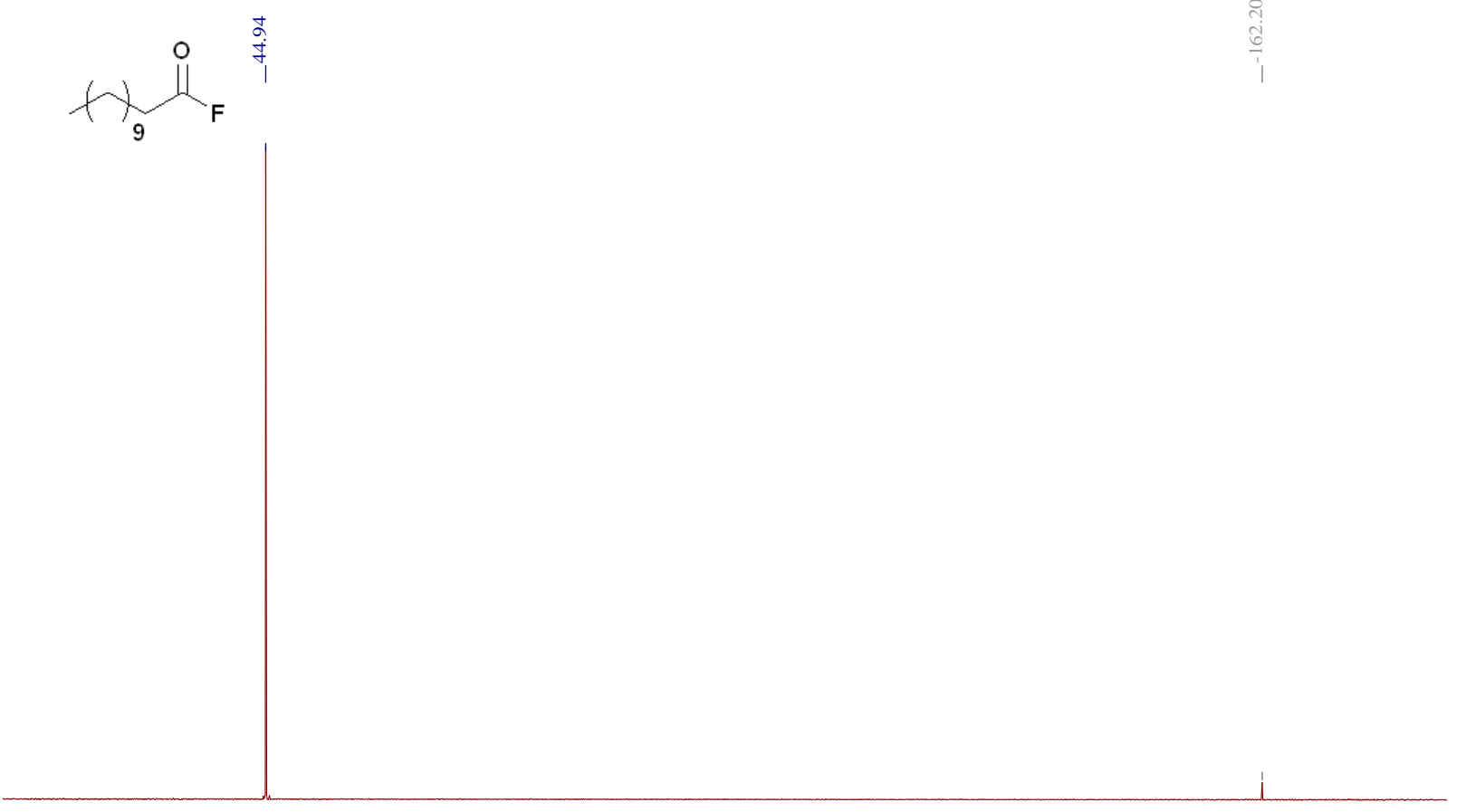

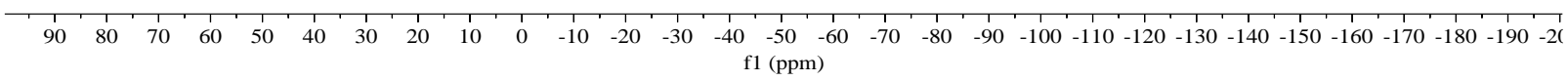
4-(N,N-Dipropylsulfamoyl)benzoyl fluoride (1w).

${ }^{1}$ H NMR (300 MHz, $\left.\mathrm{CDCl}_{3}\right)$<smiles>CCCN(CCC)S(=O)(=O)c1ccc(C(=O)O)cc1</smiles>
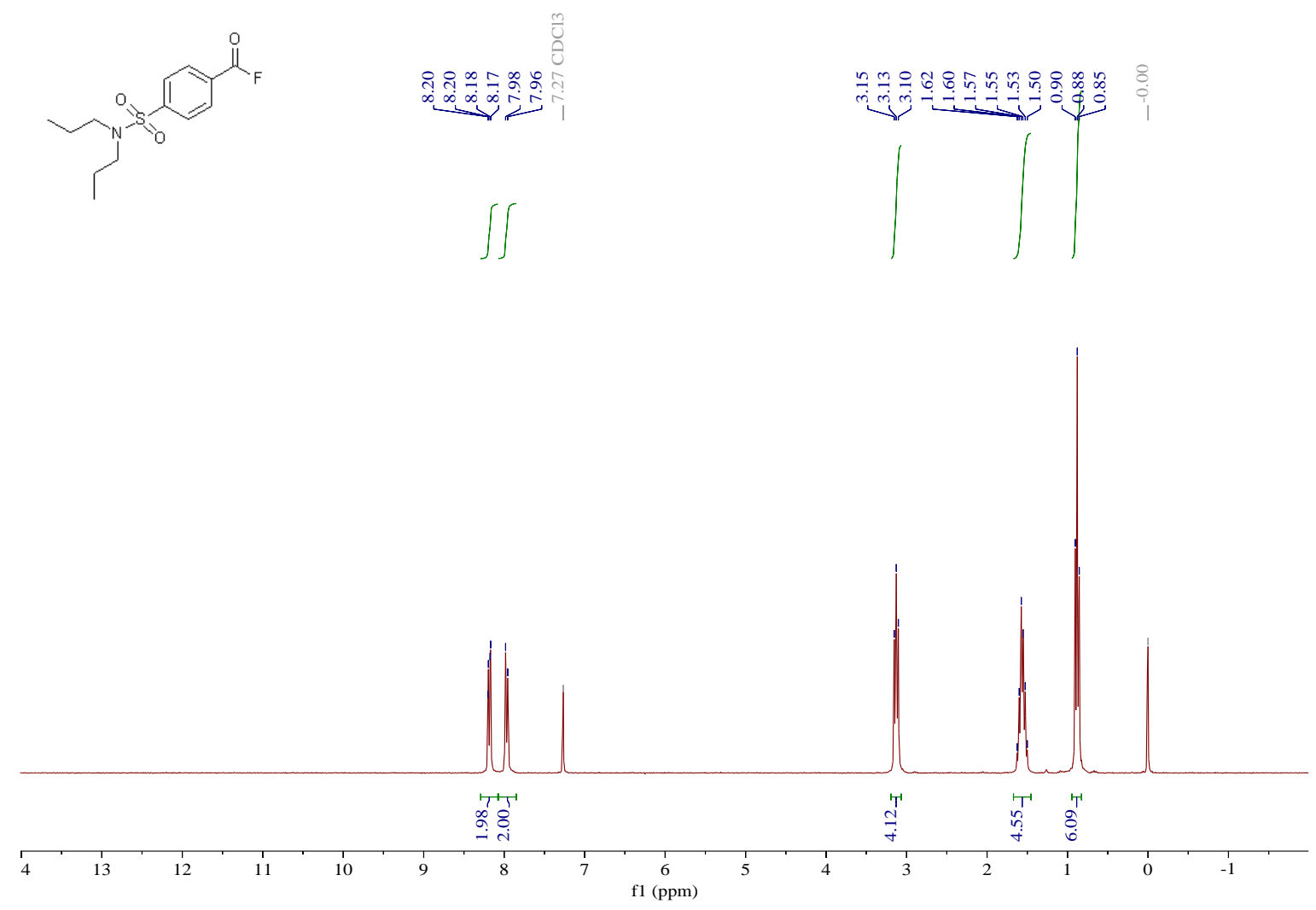
${ }^{19}$ F NMR (282 MHz, $\left.\mathrm{CDCl}_{3}\right)$

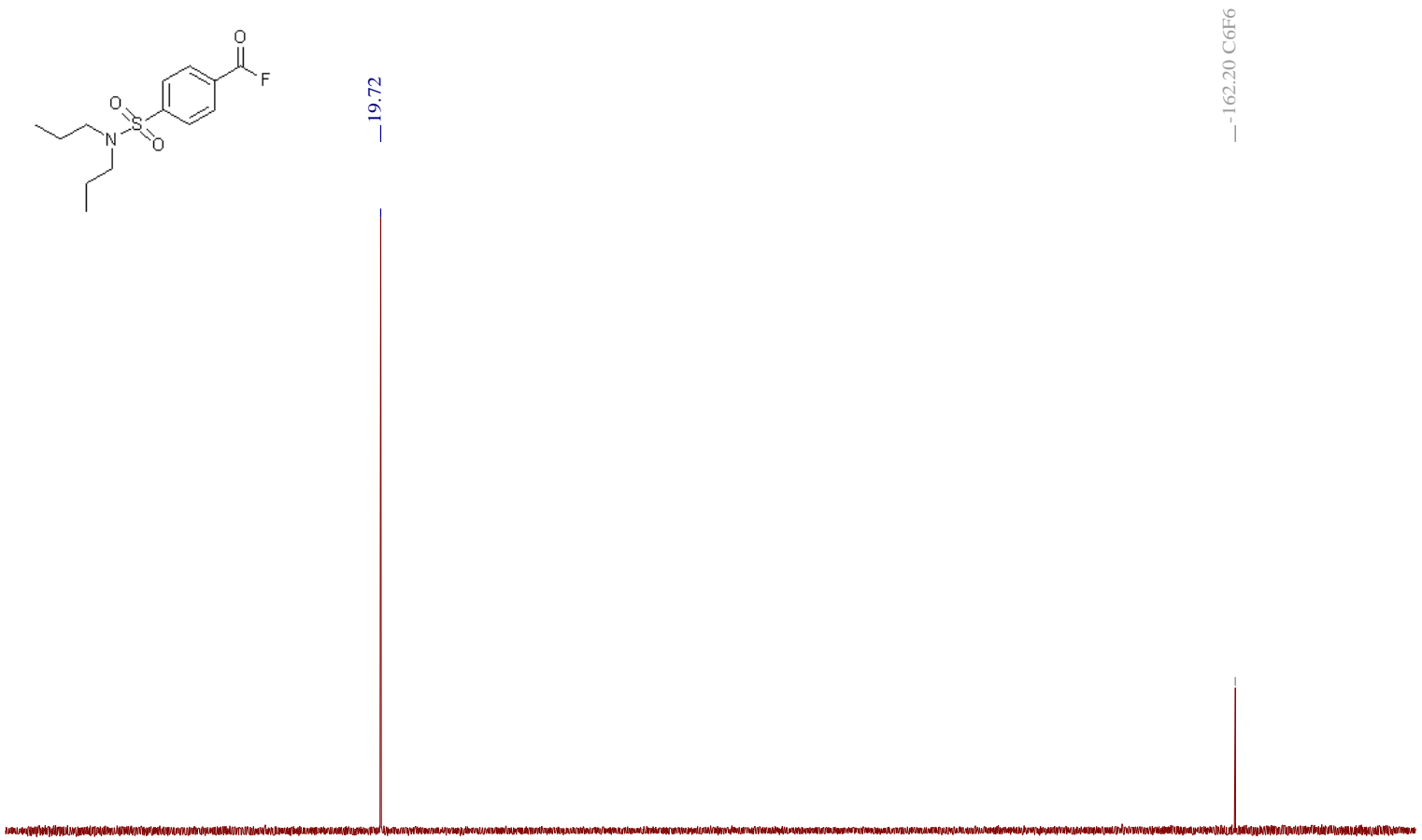

$\begin{array}{lllllllllllllllllllllllllllllllllll}90 & 80 & 70 & 60 & 50 & 40 & 30 & 20 & 10 & 0 & -10 & -20 & -30 & -40 & -50 & -60 & -70 & -80 & -90 & -100 & -110 & -120 & -130 & -140 & -150 & -160 & -170 & -180 & -190 & -2(\end{array}$ (8R,9S,13S,14S)-13-Methyl-17-oxo-7,8,9,11,12,13,14,15,16,17-decahydro-6H-

cyclopenta[a]phenanthrene-3-carbonyl fluoride (1x).

${ }^{1} \mathrm{H}$ NMR (300 MHz, $\left.\mathrm{CDCl}_{3}\right)$
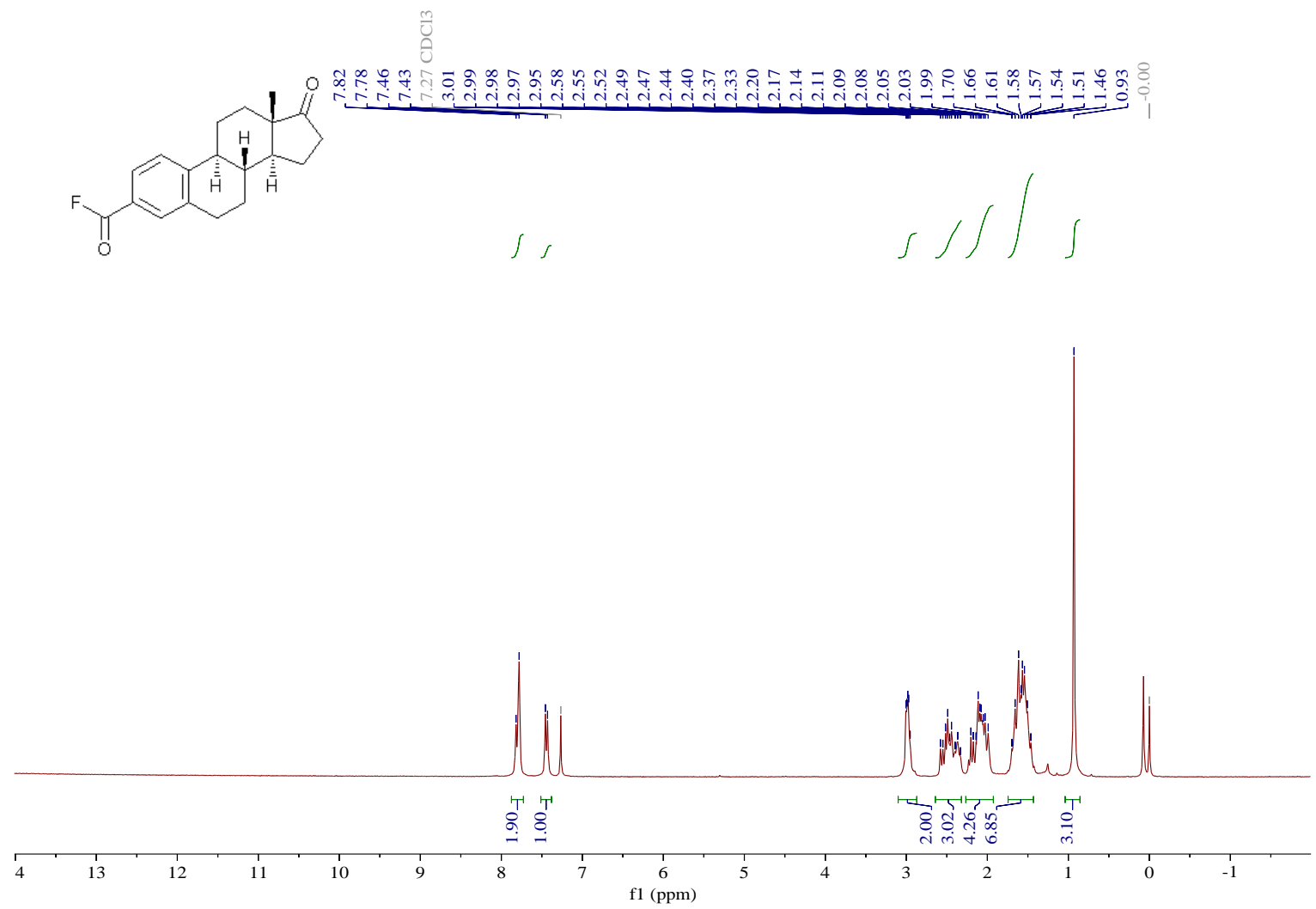
${ }^{19}$ F NMR (282 MHz, $\left.\mathrm{CDCl}_{3}\right)$
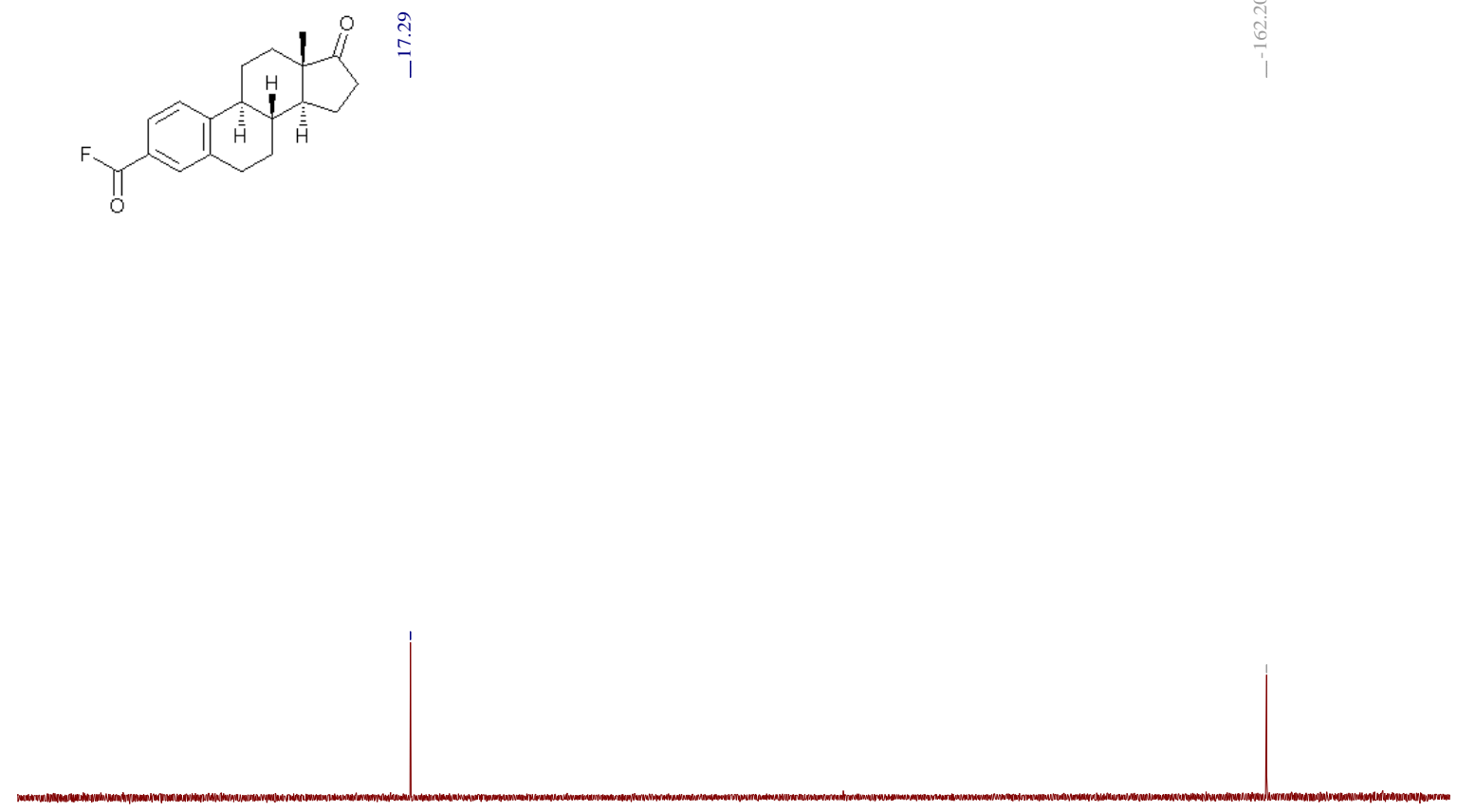

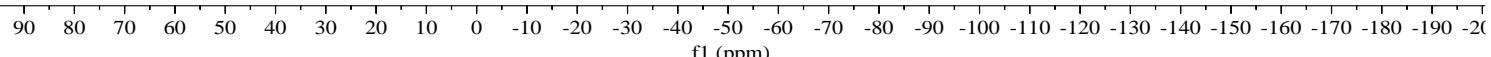
4-Ethylbenzoyl fluoride (1y).

${ }^{1} \mathrm{H}$ NMR (300 MHz, $\left.\mathrm{CDCl}_{3}\right)$
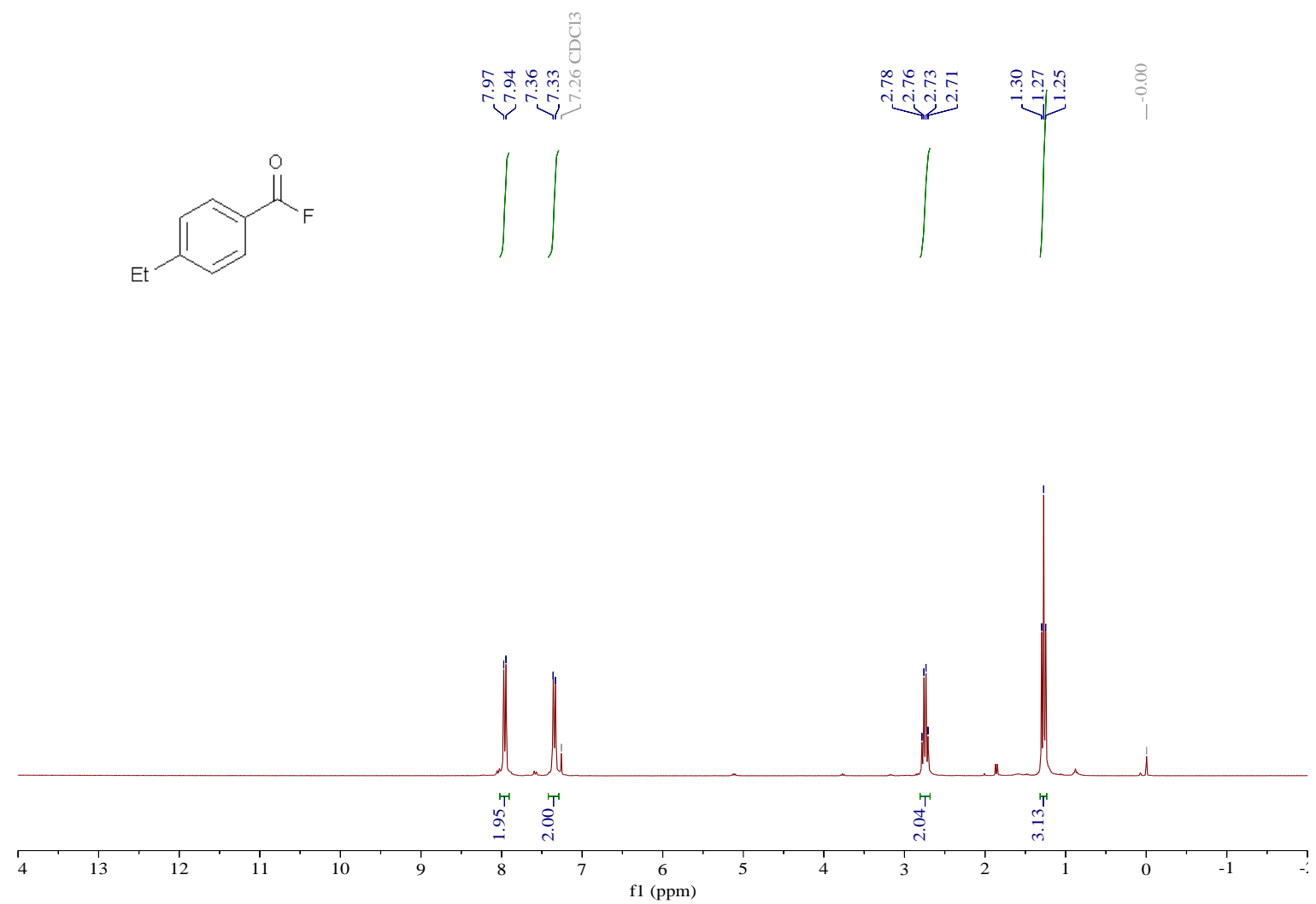
${ }^{19}$ F NMR (282 MHz, $\left.\mathrm{CDCl}_{3}\right)$<smiles>CCc1ccc(C(=O)F)cc1</smiles>

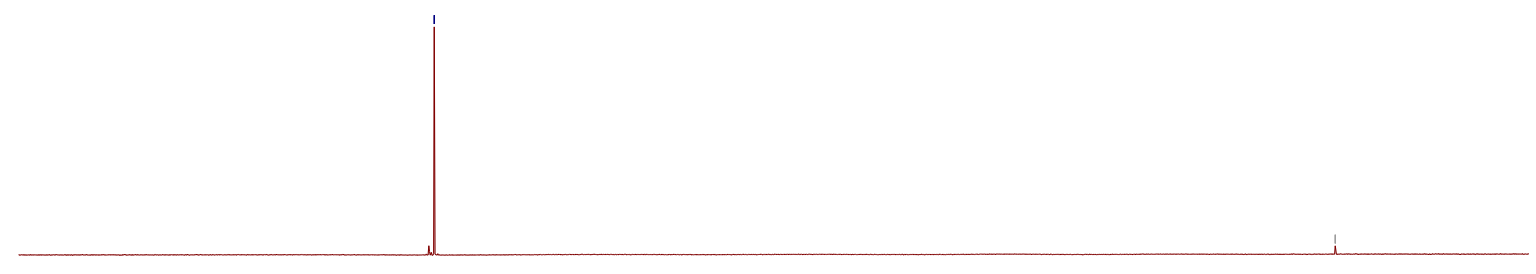

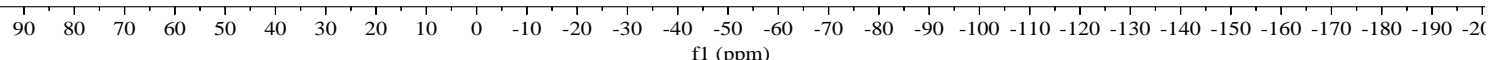
4-(Trifluoromethoxy)benzoyl fluoride (1z).

${ }^{1} \mathrm{H}$ NMR (300 MHz, $\left.\mathrm{CDCl}_{3}\right)$
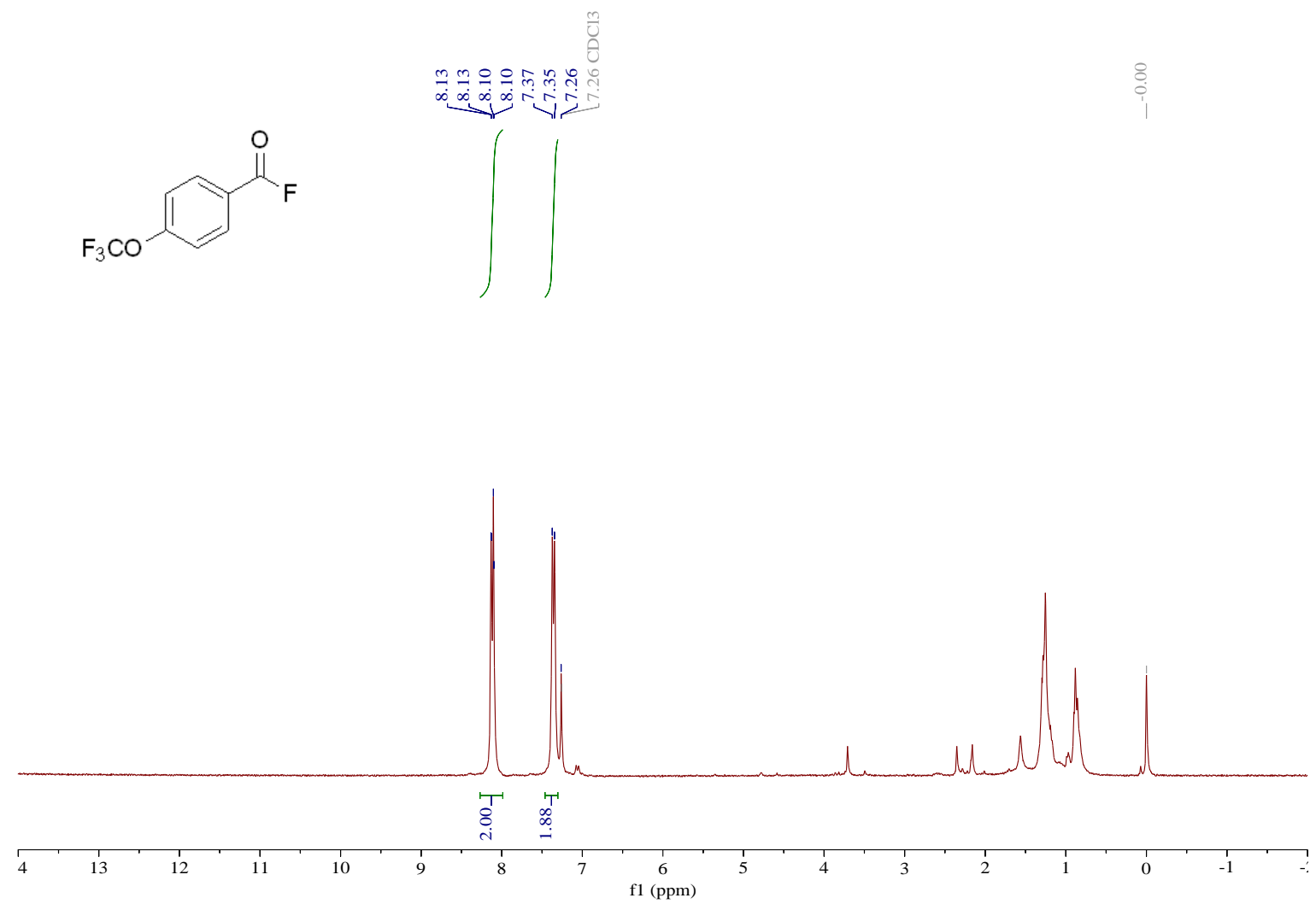
${ }^{19}$ F NMR (282 MHz, $\left.\mathrm{CDCl}_{3}\right)$

$\stackrel{\infty}{\infty}$<smiles>CCCc1ccc(OC(F)(F)F)cc1</smiles>

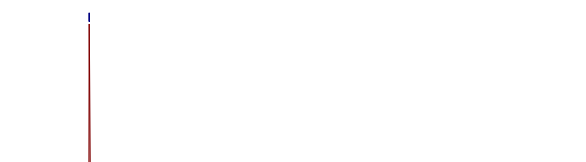

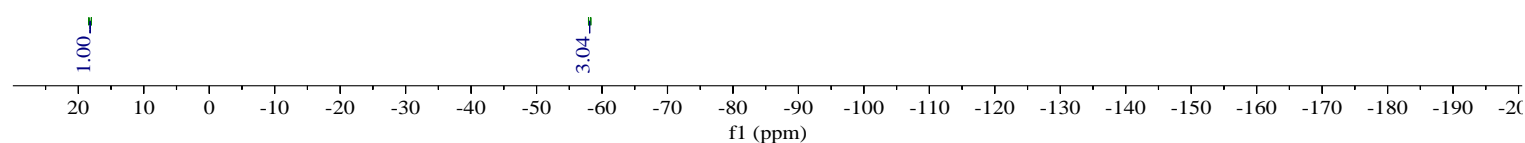

4-Cyanobenzoyl fluoride (1za).

\section{${ }^{1} \mathrm{H}$ NMR (300 MHz, $\mathrm{CDCl}_{3}$ )}
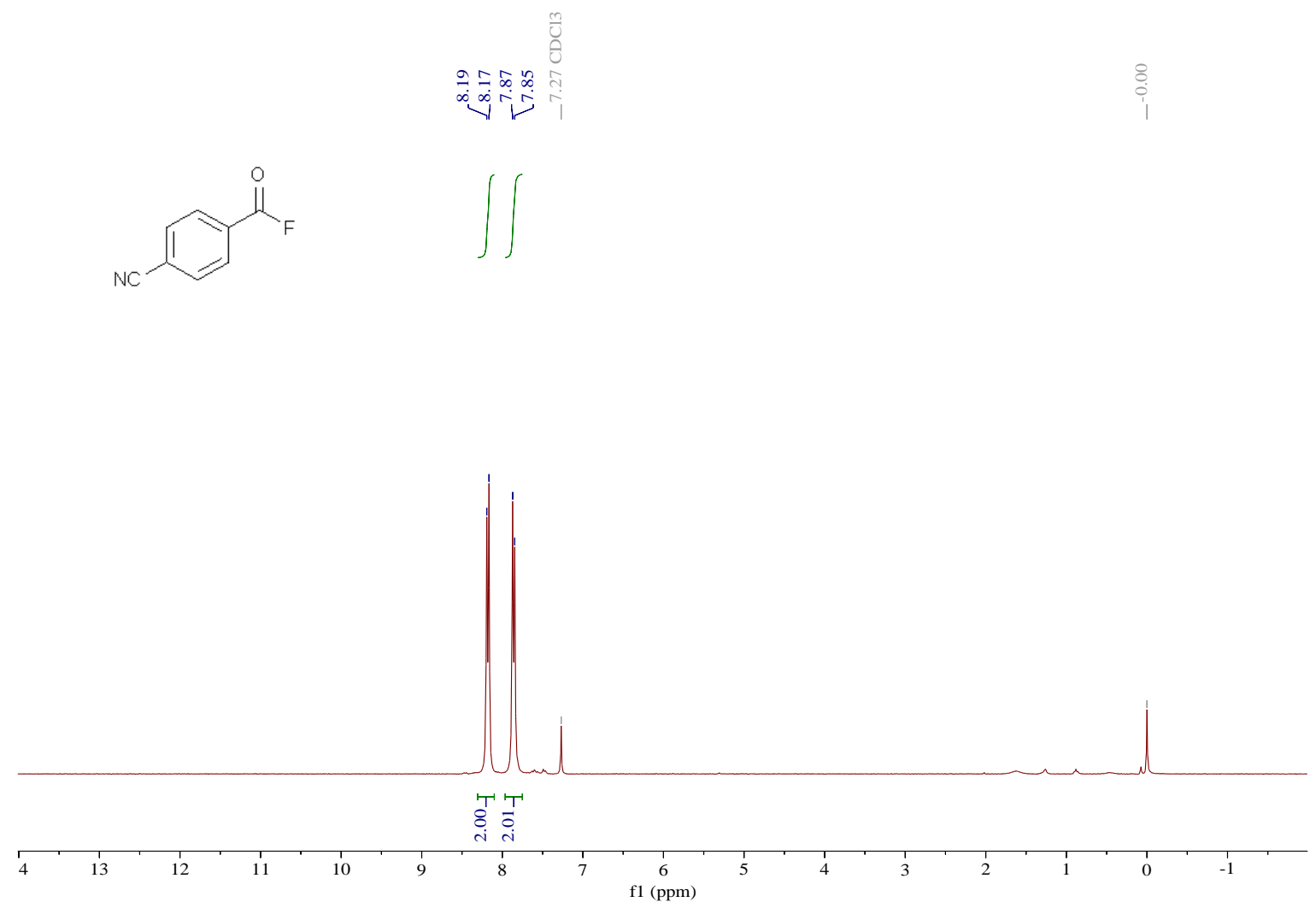
${ }^{19}$ F NMR (282 MHz, $\mathrm{CDCl}_{3}$ )

ลิ

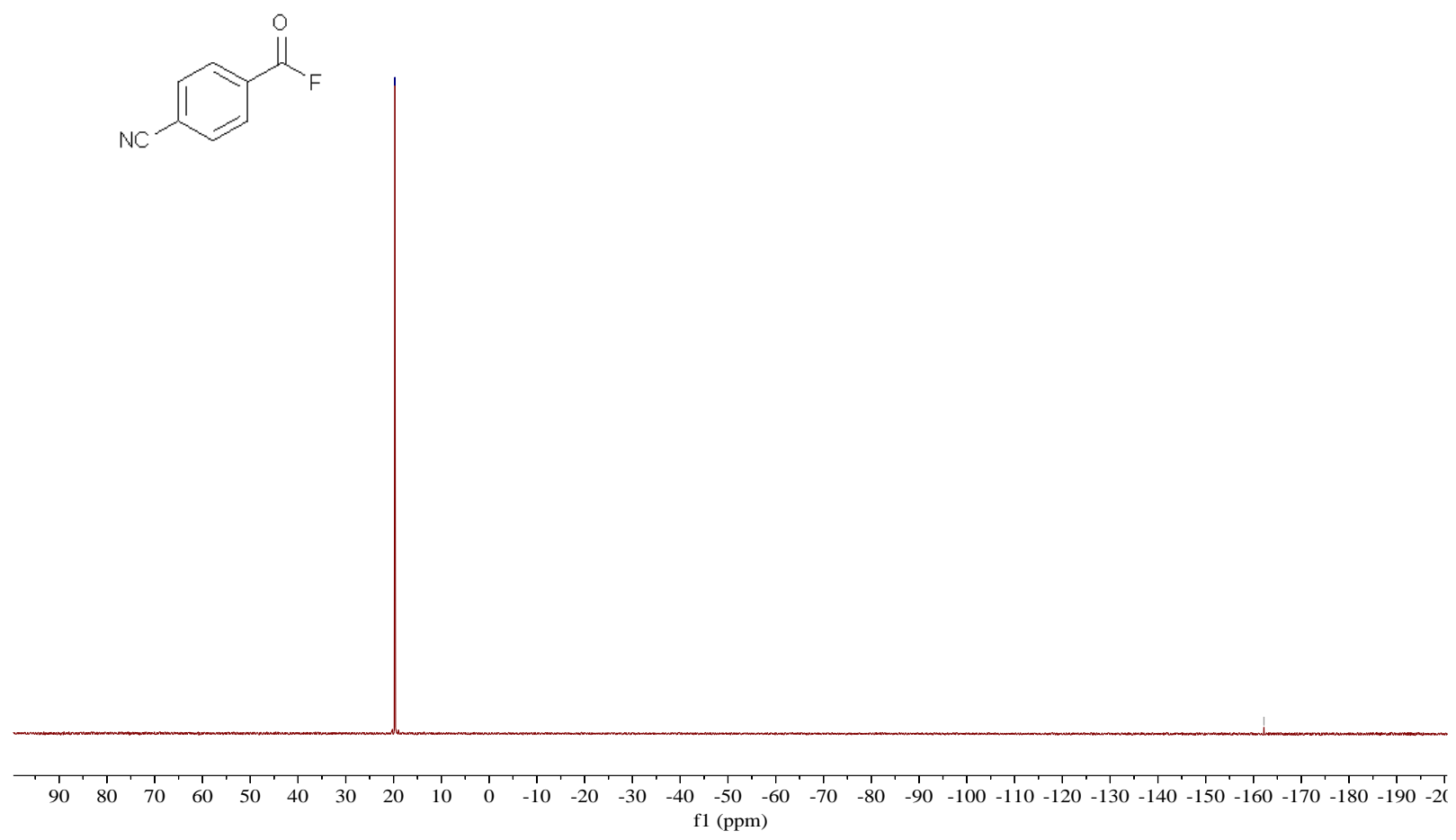

3-Bromobenzoyl fluoride (1zb).

\section{${ }^{1} \mathrm{H}$ NMR (300 MHz, $\mathrm{CDCl}_{3}$ )}
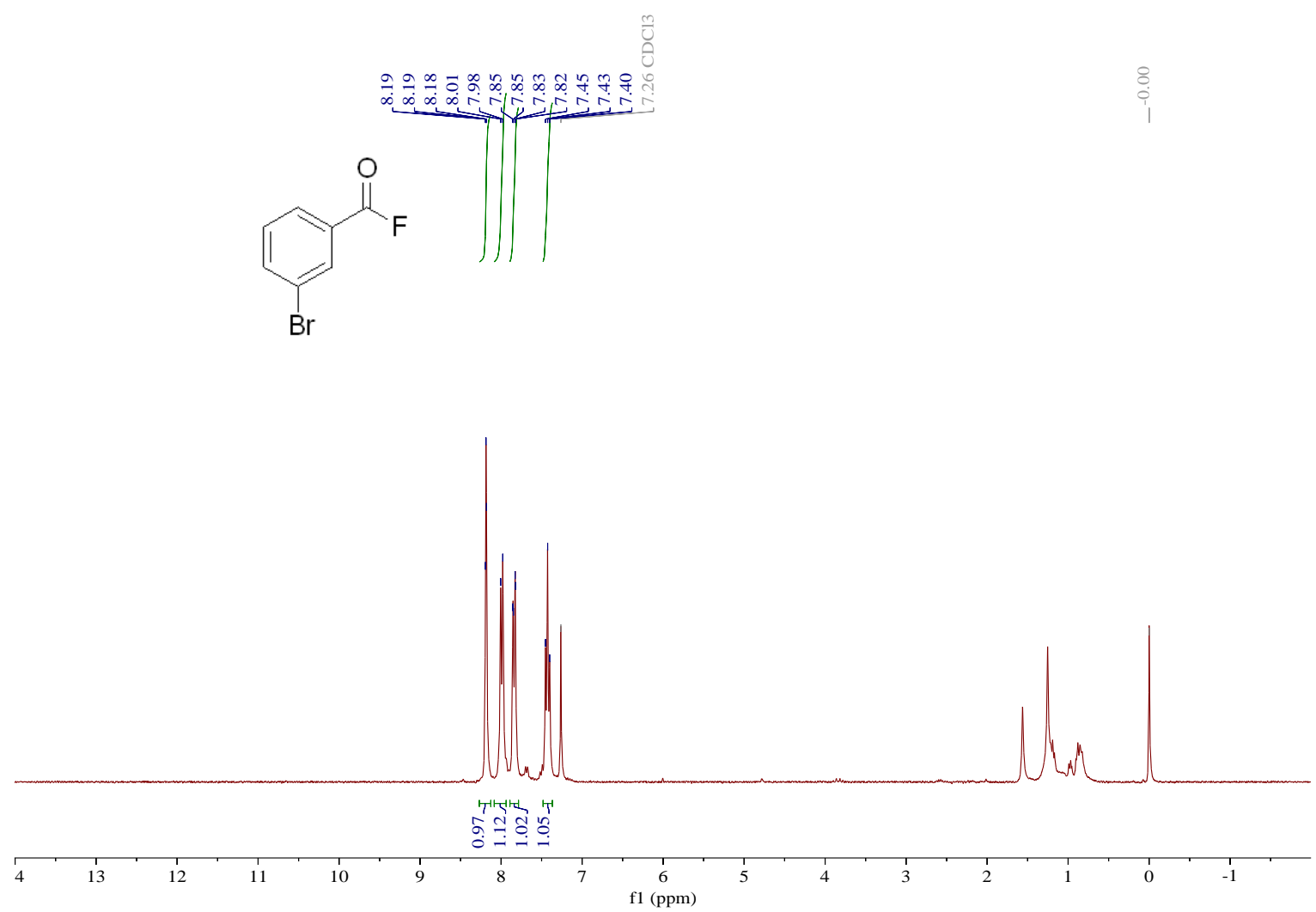
${ }^{19}$ F NMR (282 MHz, $\mathrm{CDCl}_{3}$ )

0
10
$\infty$
1
1<smiles>O=C(F)c1cccc(Br)c1</smiles>

\begin{tabular}{rrrrrrrrrrrrrrrrrrrrrrrrr}
\hline & 10 & 10 & 0 & -10 & -20 & -30 & -40 & -50 & -60 & -70 & -8 & -90 & -100 & -110 & -120 & -130 & -140 & -150 & -160 & -170 & -180 & -190 & -26 \\
\hline
\end{tabular}

2-Nitrobenzoyl fluoride (1zc).

${ }^{1} \mathrm{H}$ NMR (300 MHz, $\mathrm{CDCl}_{3}$ )<smiles>O=C(F)c1ccccc1[N+](=O)[O-]</smiles>

$\underbrace{0}$

1

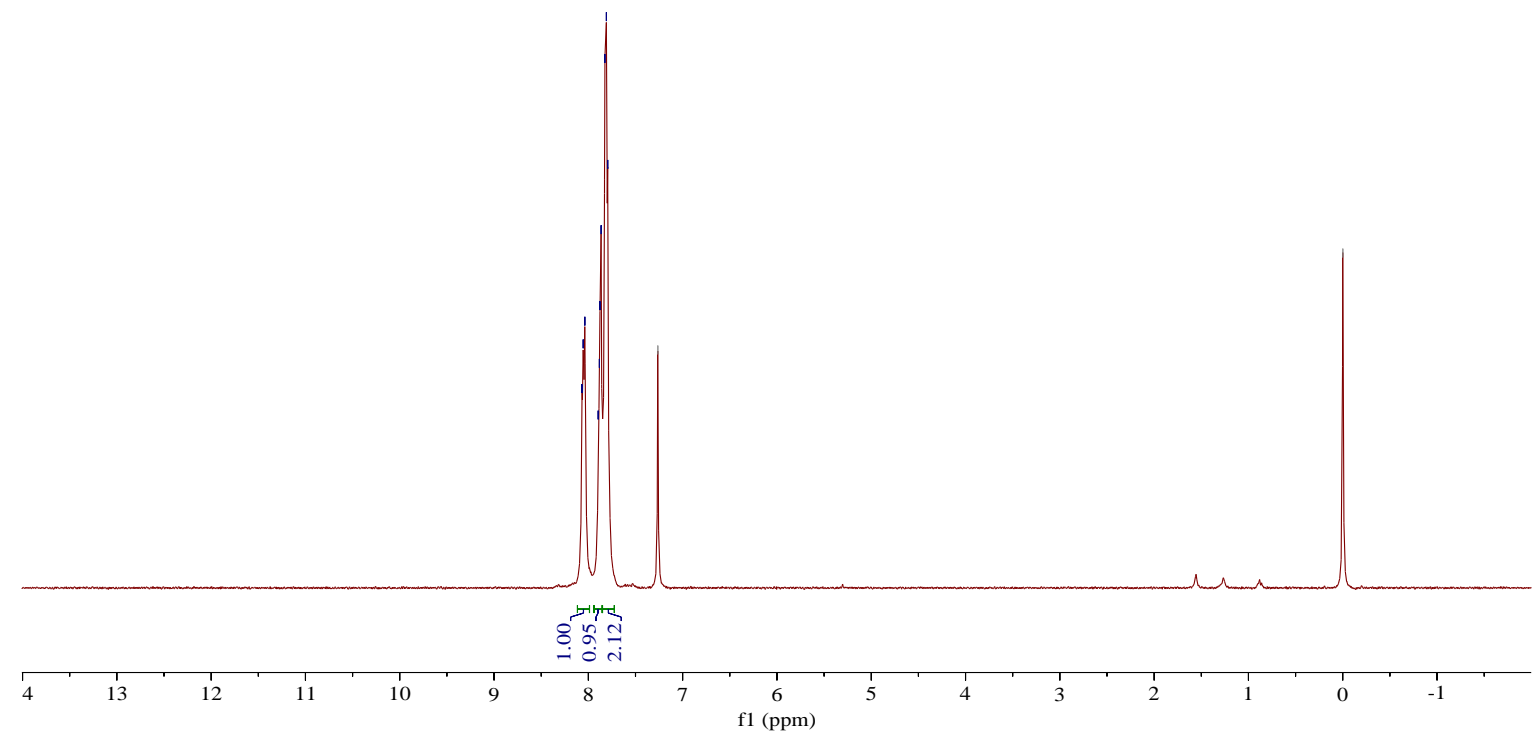


${ }^{19}$ F NMR (282 MHz, $\left.\mathrm{CDCl}_{3}\right)$
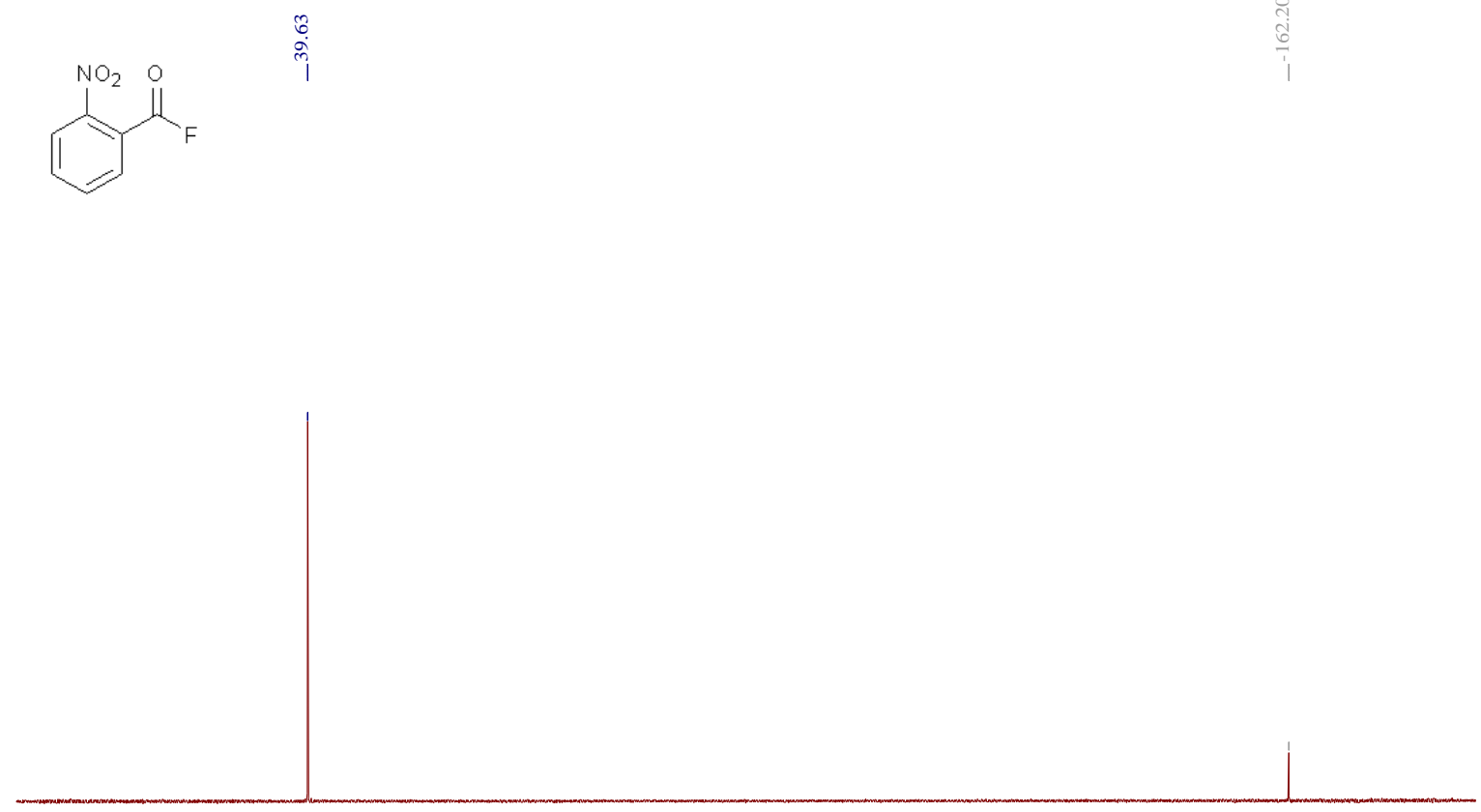

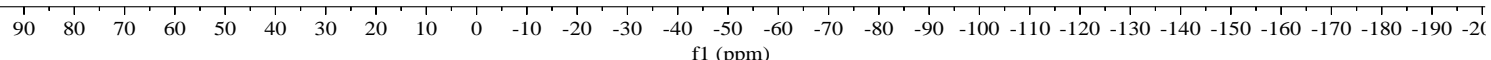

1-Bromo-2-naphthoyl fluoride (1zd).

${ }^{1} \mathrm{H}$ NMR (300 MHz, $\left.\mathrm{CDCl}_{3}\right)$
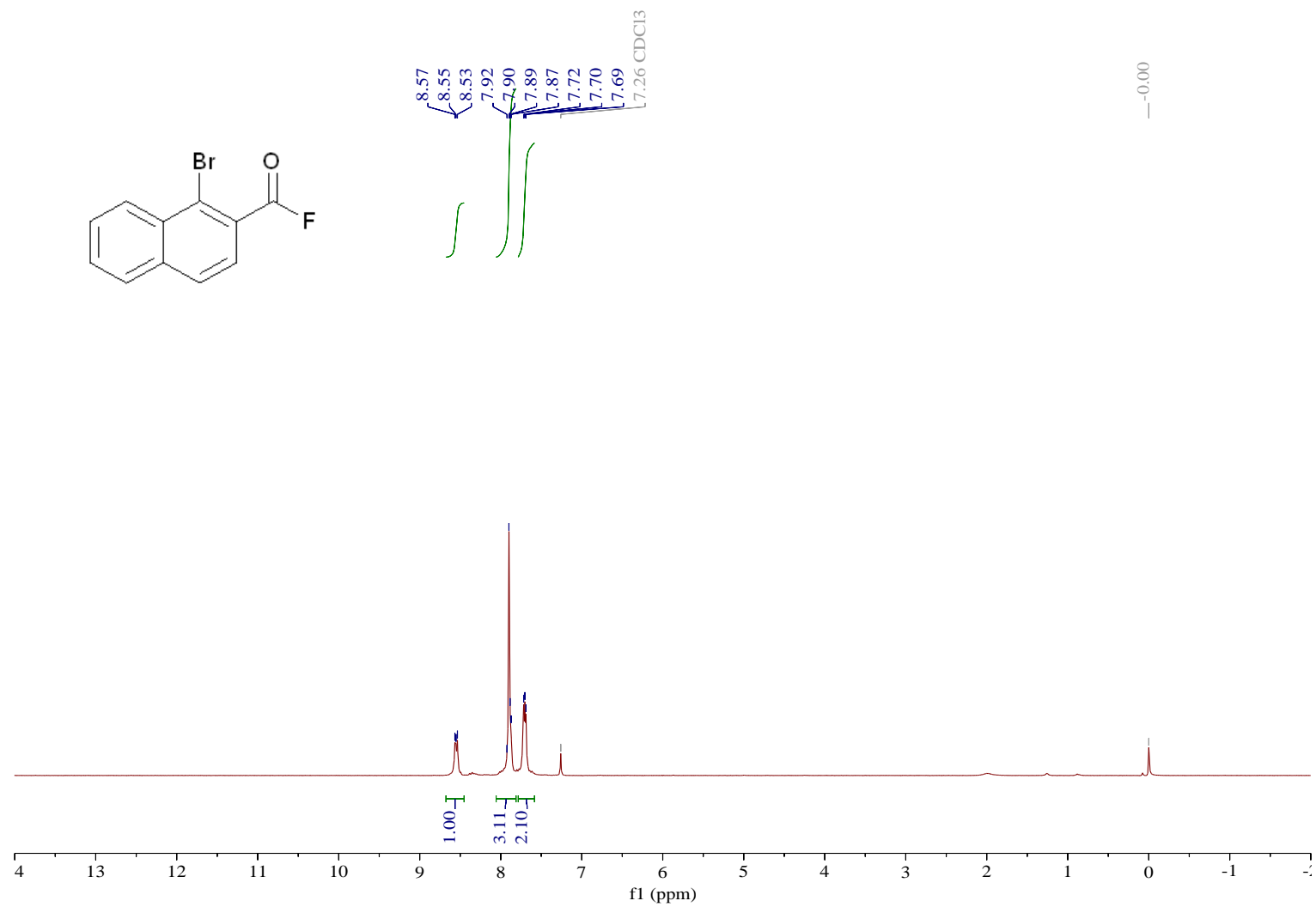
${ }^{13} \mathrm{C}$ NMR (126 MHz, $\left.\mathrm{CDCl}_{3}\right)$

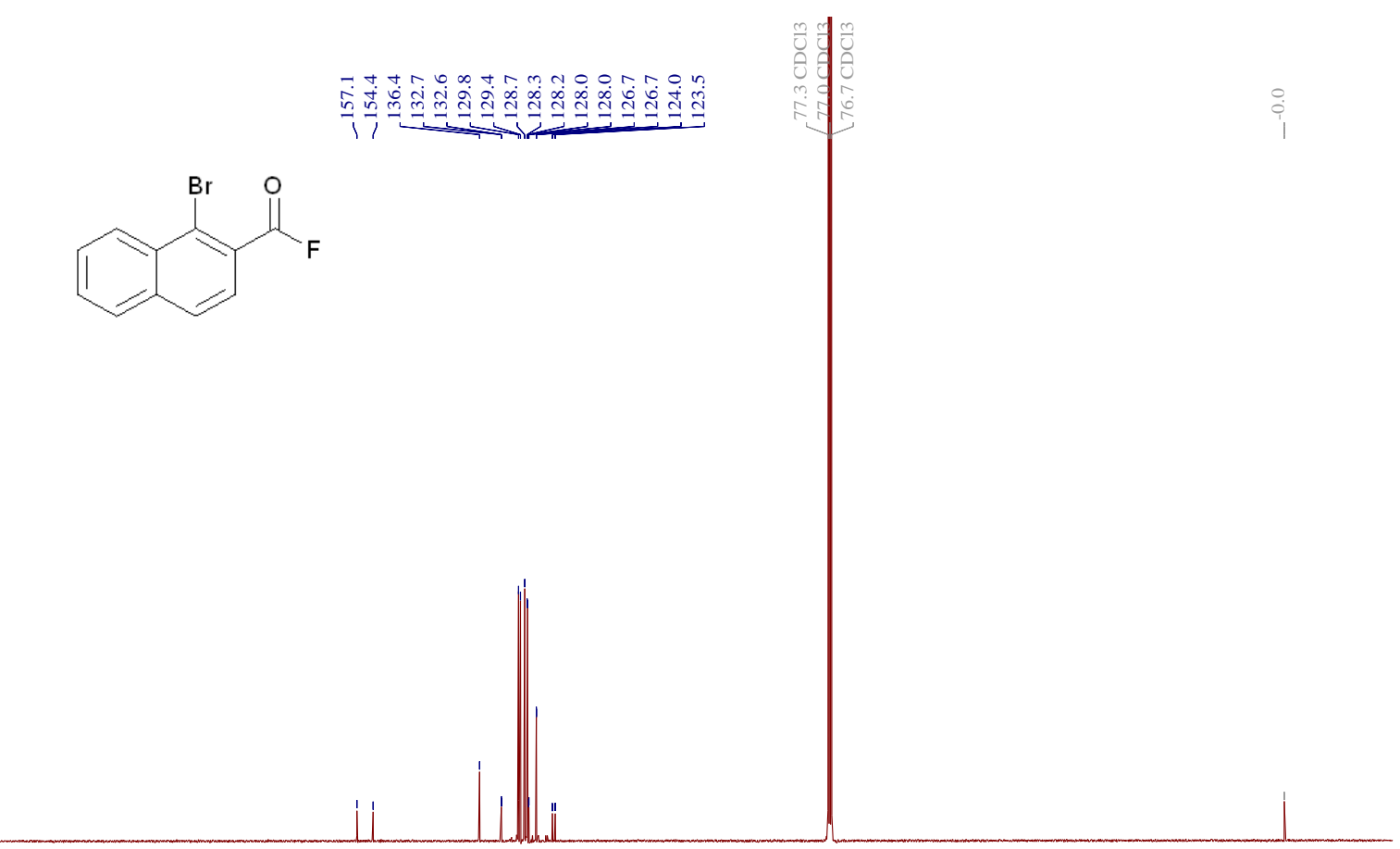

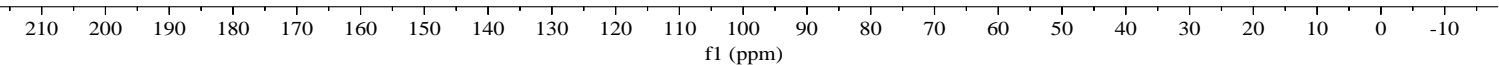

${ }^{19}$ F NMR (282 MHz, $\mathrm{CDCl}_{3}$ )<smiles>O=C(O)c1ccc2ccccc2c1Br</smiles>

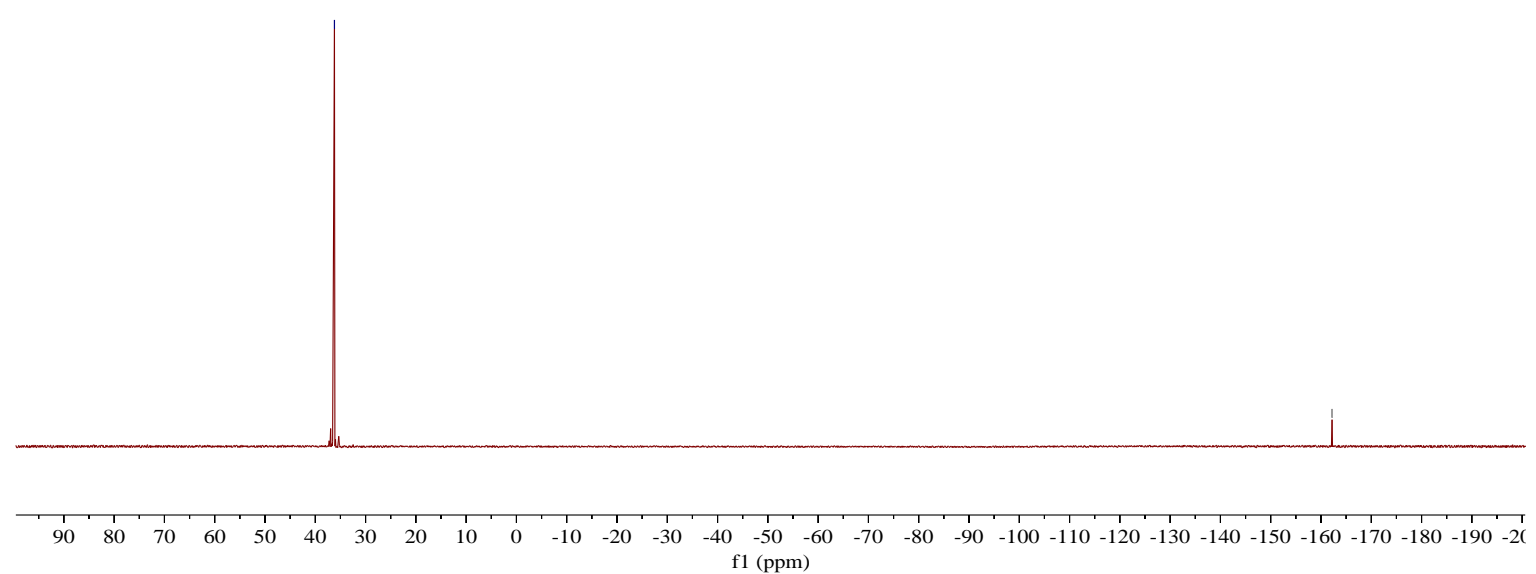


3,5-Dibromobenzoyl fluoride (1ze).

${ }^{1} \mathrm{H}$ NMR (300 MHz, $\left.\mathrm{CDCl}_{3}\right)$
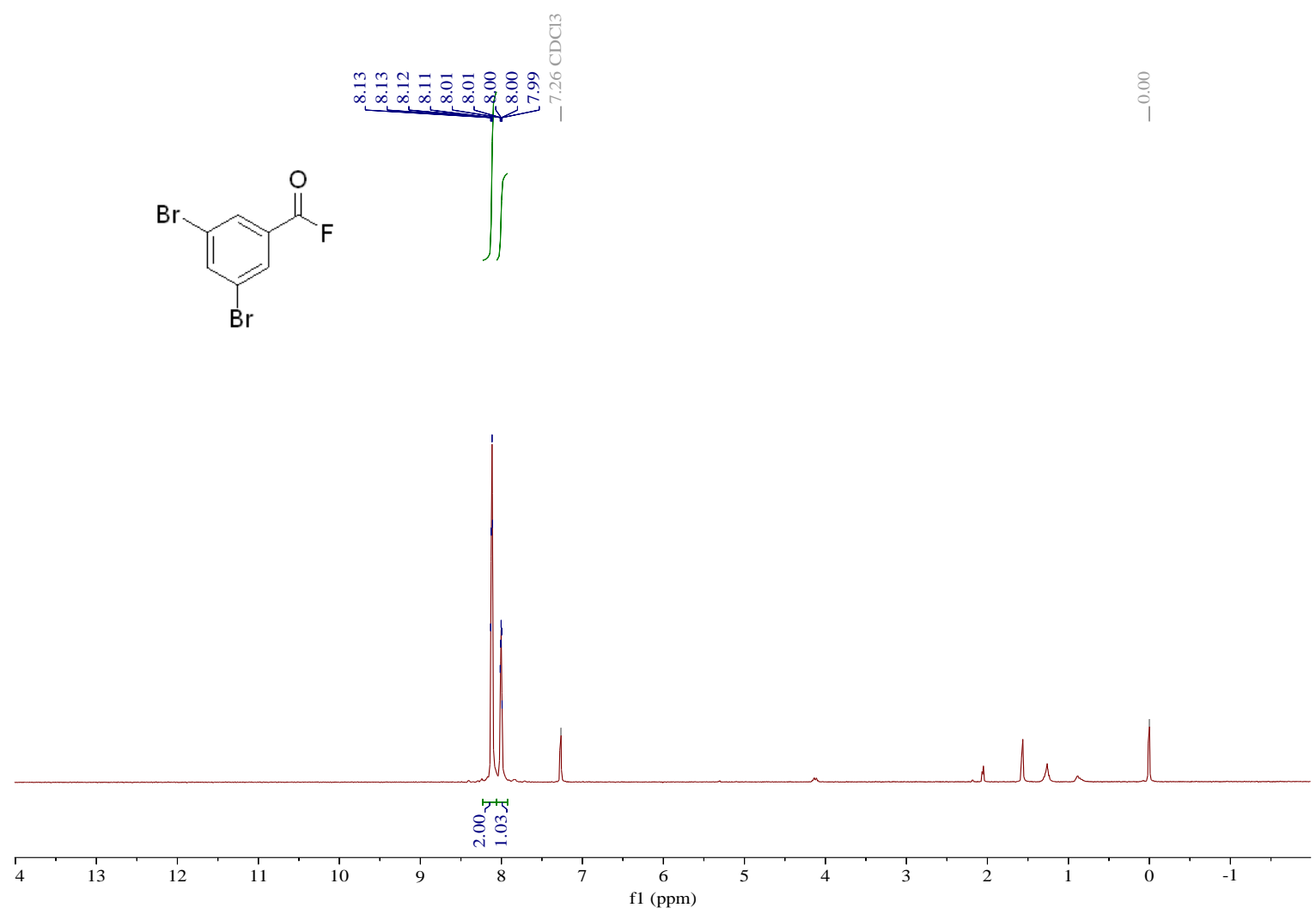

${ }^{13} \mathrm{C}$ NMR (126 MHz, $\left.\mathrm{CDCl}_{3}\right)$

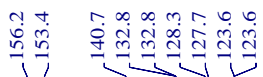<smiles>O=C(F)c1cc(Br)cc(Br)c1</smiles>

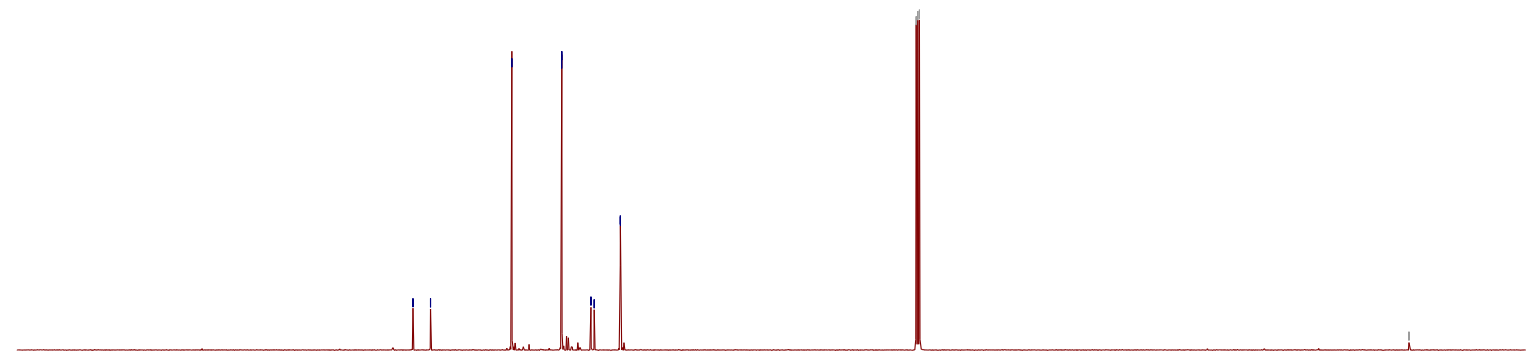

$\begin{array}{llllllllllllllllllllllll}1 & 1 & 200 & 190 & 180 & 170 & 160 & 150 & 140 & 130 & 120 & 110 & 100 & 90 & 80 & 70 & 60 & 50 & 40 & 30 & 20 & 10 & 0 & -10\end{array}$ 
${ }^{19}$ F NMR (282 MHz, $\mathrm{CDCl}_{3}$ )

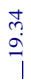<smiles>O=C(F)c1cc(Br)cc(Br)c1</smiles>

\begin{tabular}{llllllllllllllllllllllllll}
20 & 10 & 0 & -10 & -20 & -30 & -40 & -50 & -60 & -70 & -80 & -90 & -100 & -110 & -120 & -130 & -140 & -150 & -160 & -170 & -180 & -190 & -20 \\
\hline
\end{tabular}

3,4-Dichlorobenzoyl fluoride (1zf).

${ }^{1} \mathrm{H}$ NMR (300 MHz, $\mathrm{CDCl}_{3}$ )<smiles>O=Cc1ccc(Cl)c(Cl)c1</smiles>
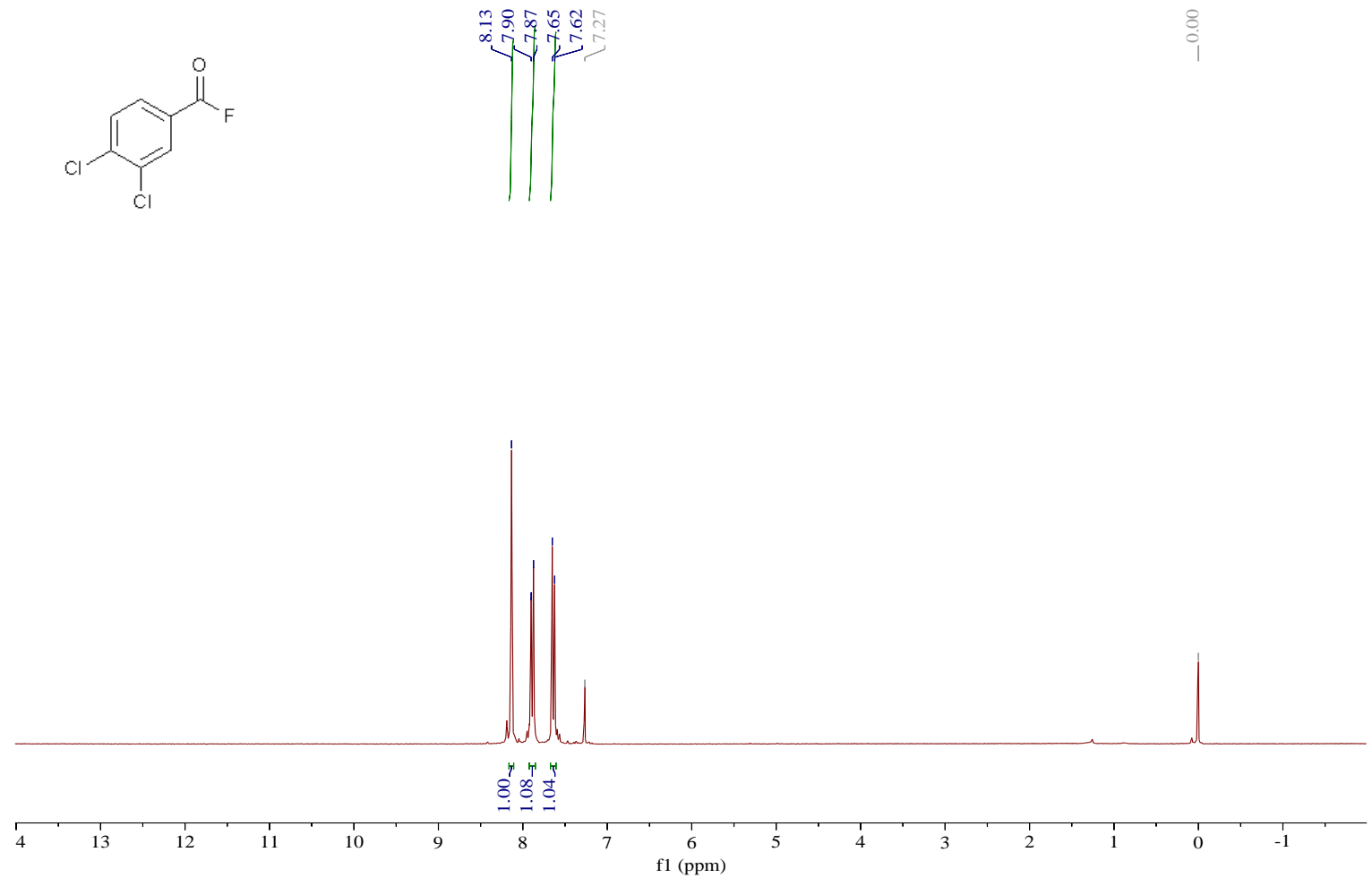
${ }^{13} \mathrm{C}$ NMR (126 MHz, $\mathrm{CDCl}_{3}$ )<smiles>O=C(O)c1ccc(Cl)c(Cl)c1</smiles>

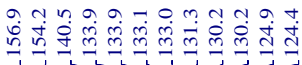

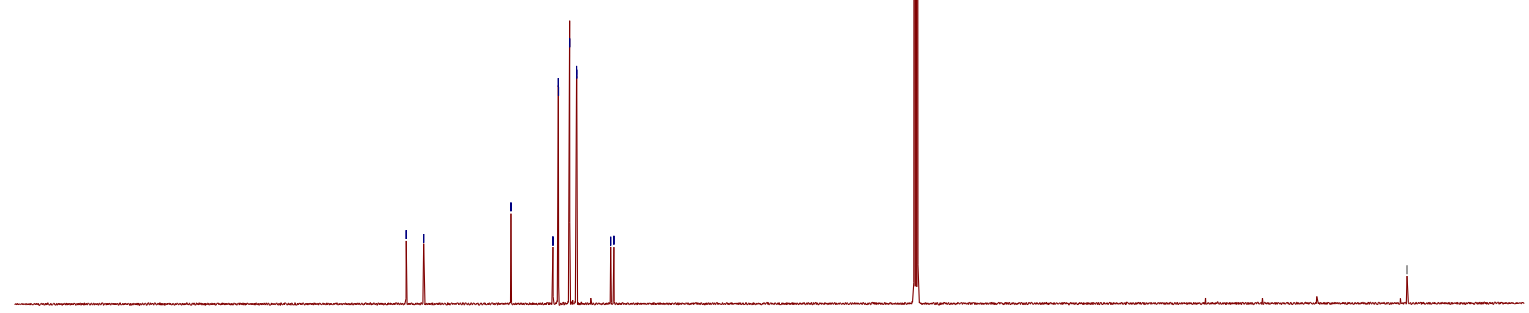

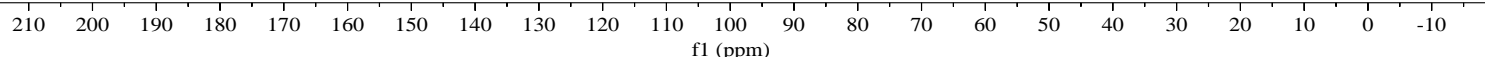

${ }^{19}$ F NMR (282 MHz, $\left.\mathrm{CDCl}_{3}\right)$

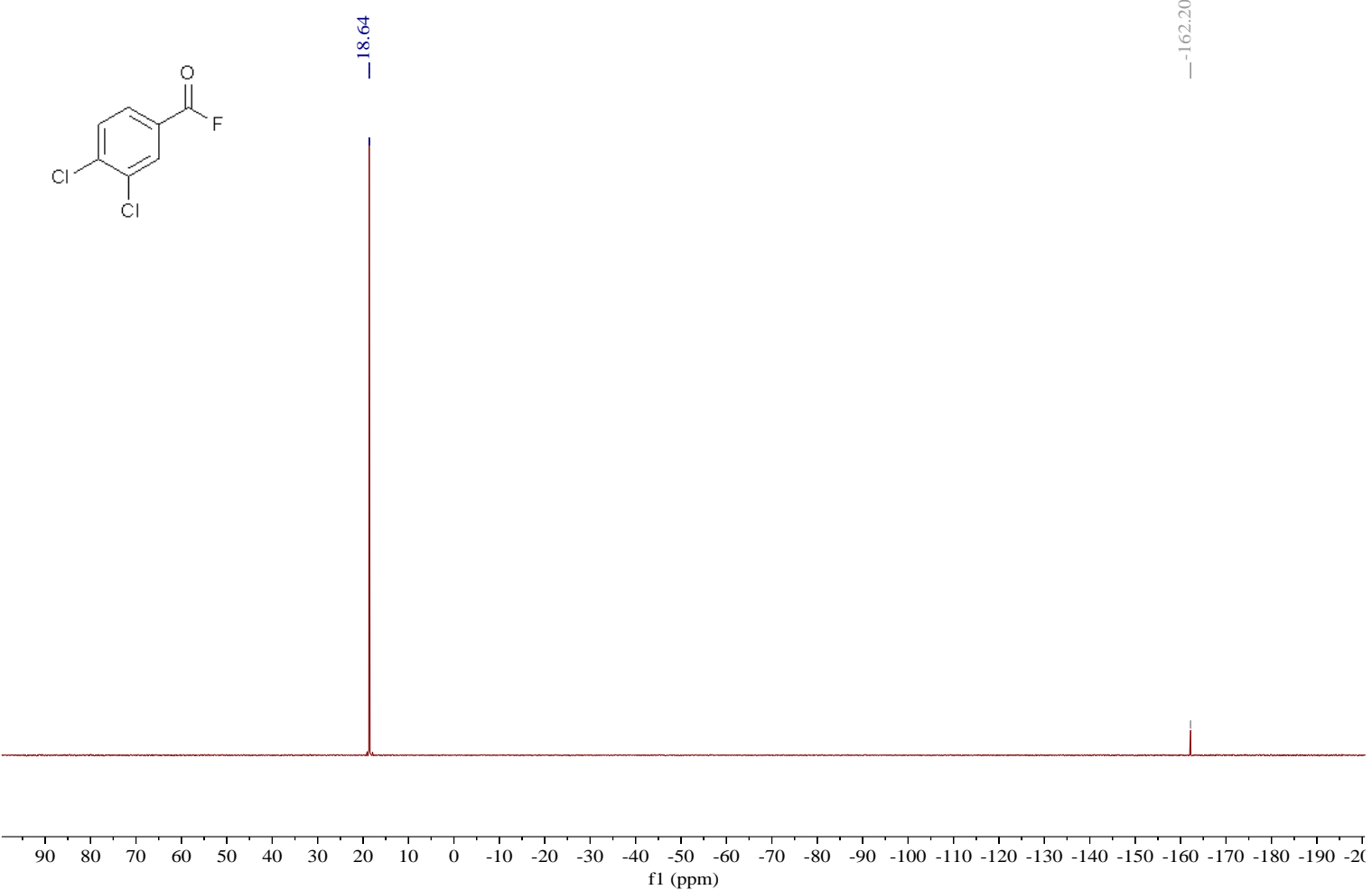


Picolinoyl fluoride (1zg).

${ }^{1} \mathrm{H}$ NMR (300 MHz, $\left.\mathrm{CDCl}_{3}\right)$<smiles>O=C(F)c1ccccn1</smiles>
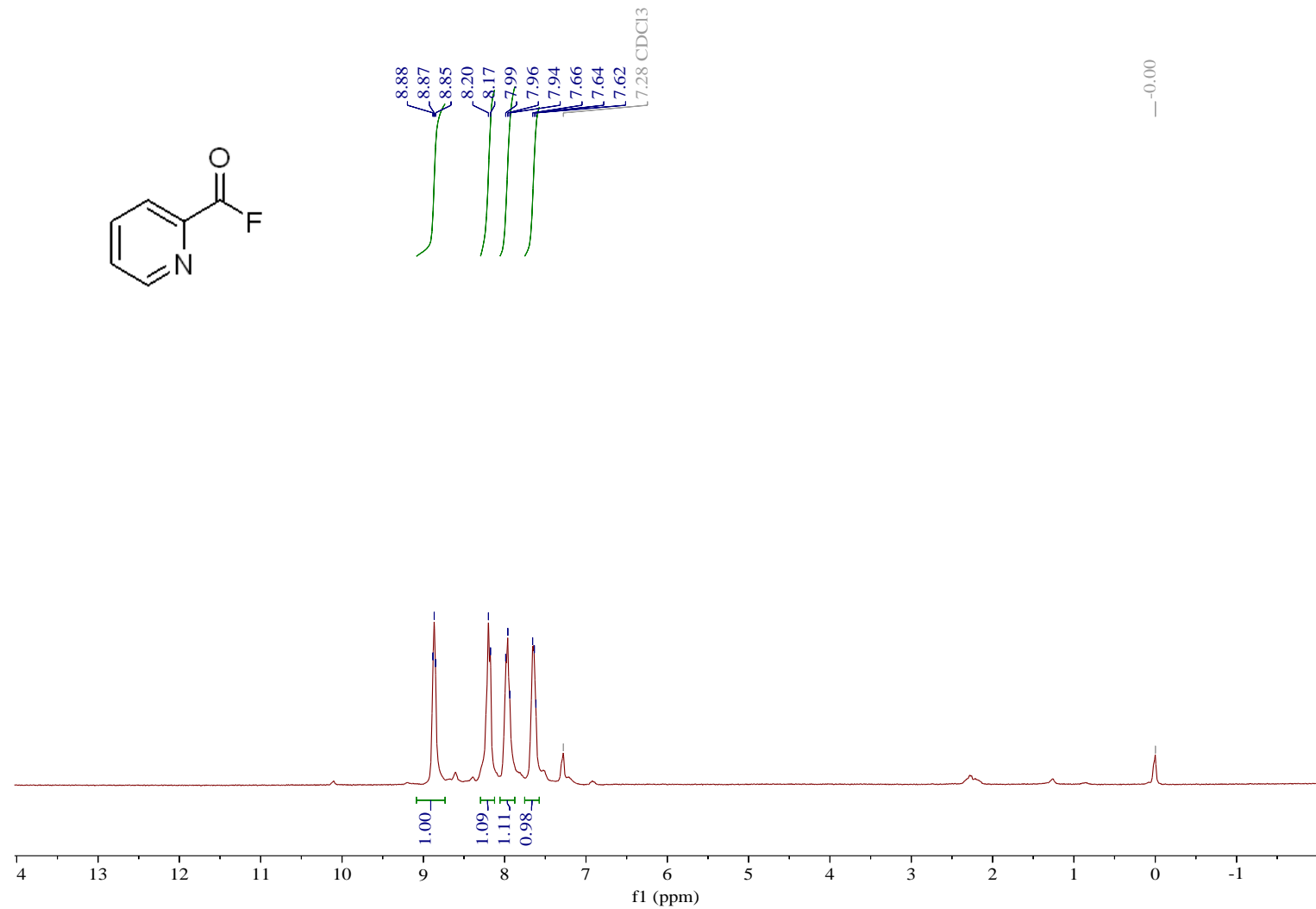

${ }^{19}$ F NMR (282 MHz, $\left.\mathrm{CDCl}_{3}\right)$<smiles>O=C(F)c1ccccn1</smiles>

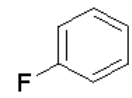


${ }^{13} \mathrm{C}$ NMR (75 MHz, $\left.\mathrm{CDCl}_{3}\right)$

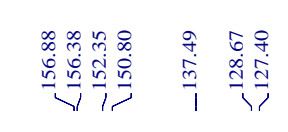<smiles>O=C(F)c1ccccn1</smiles>

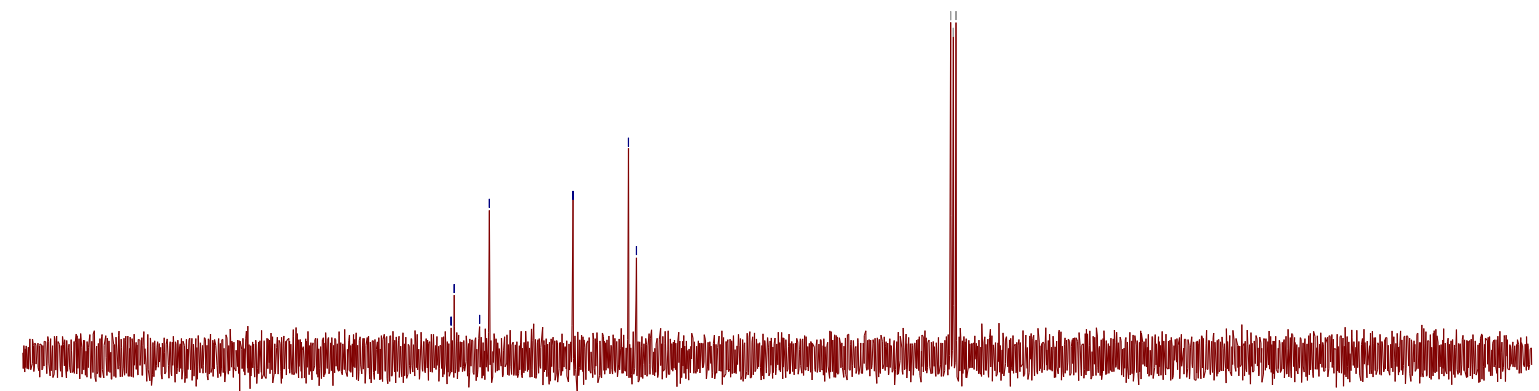

\begin{tabular}{lllllllllllllllllllllllll}
\hline & 1 \\
220 & 210 & 200 & 190 & 180 & 170 & 160 & 150 & 140 & 130 & 120 & 110 & 100 & 90 & 80 & 70 & 60 & 50 & 40 & 30 & 20 & 10 & 0 & -10
\end{tabular}

2-Bromonicotinoyl fluoride (1zh).

${ }^{1} \mathrm{H}$ NMR (300 MHz, $\left.\mathrm{CDCl}_{3}\right)$
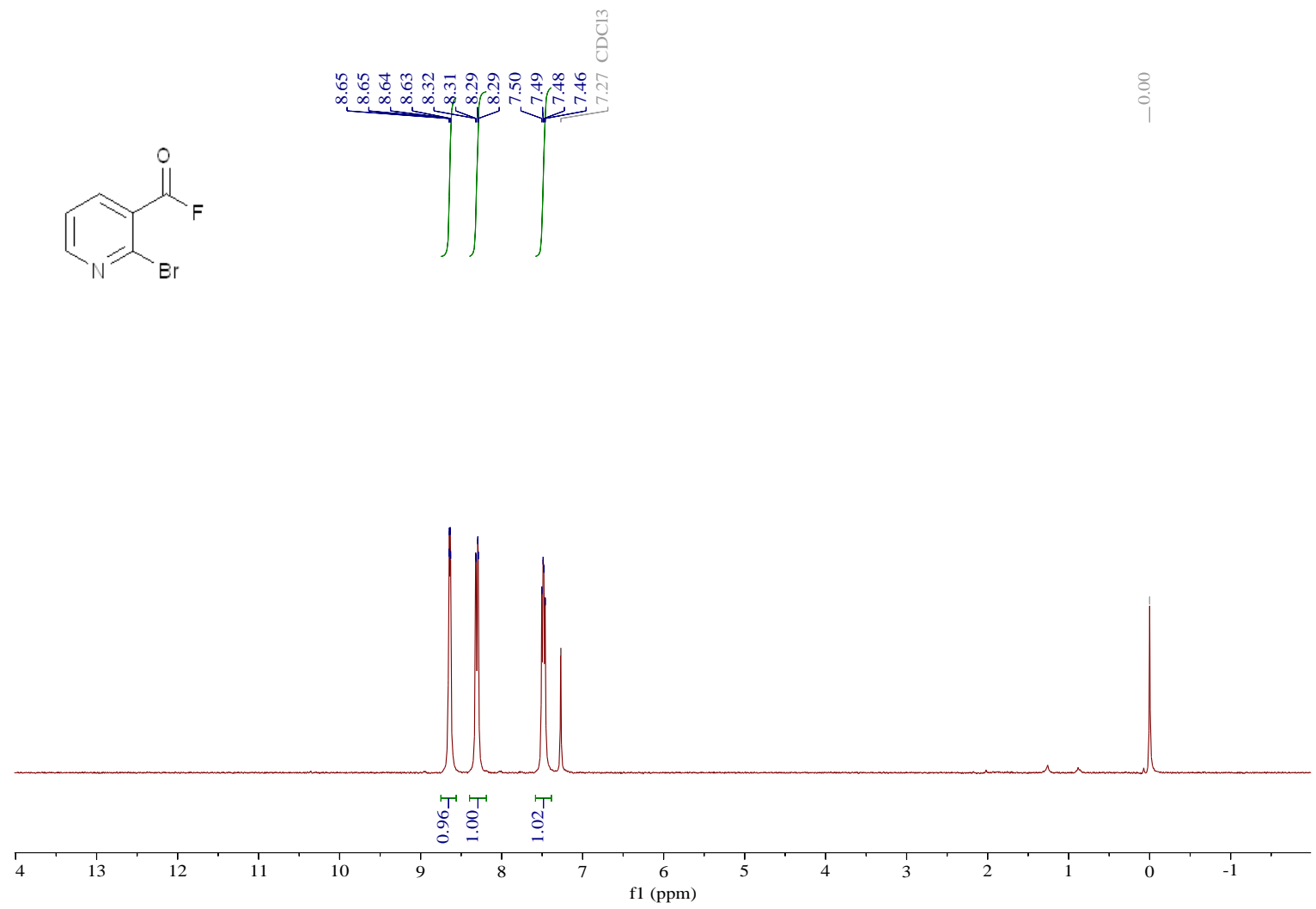
${ }^{13} \mathrm{C}$ NMR (126 MHz, $\mathrm{CDCl}_{3}$ )

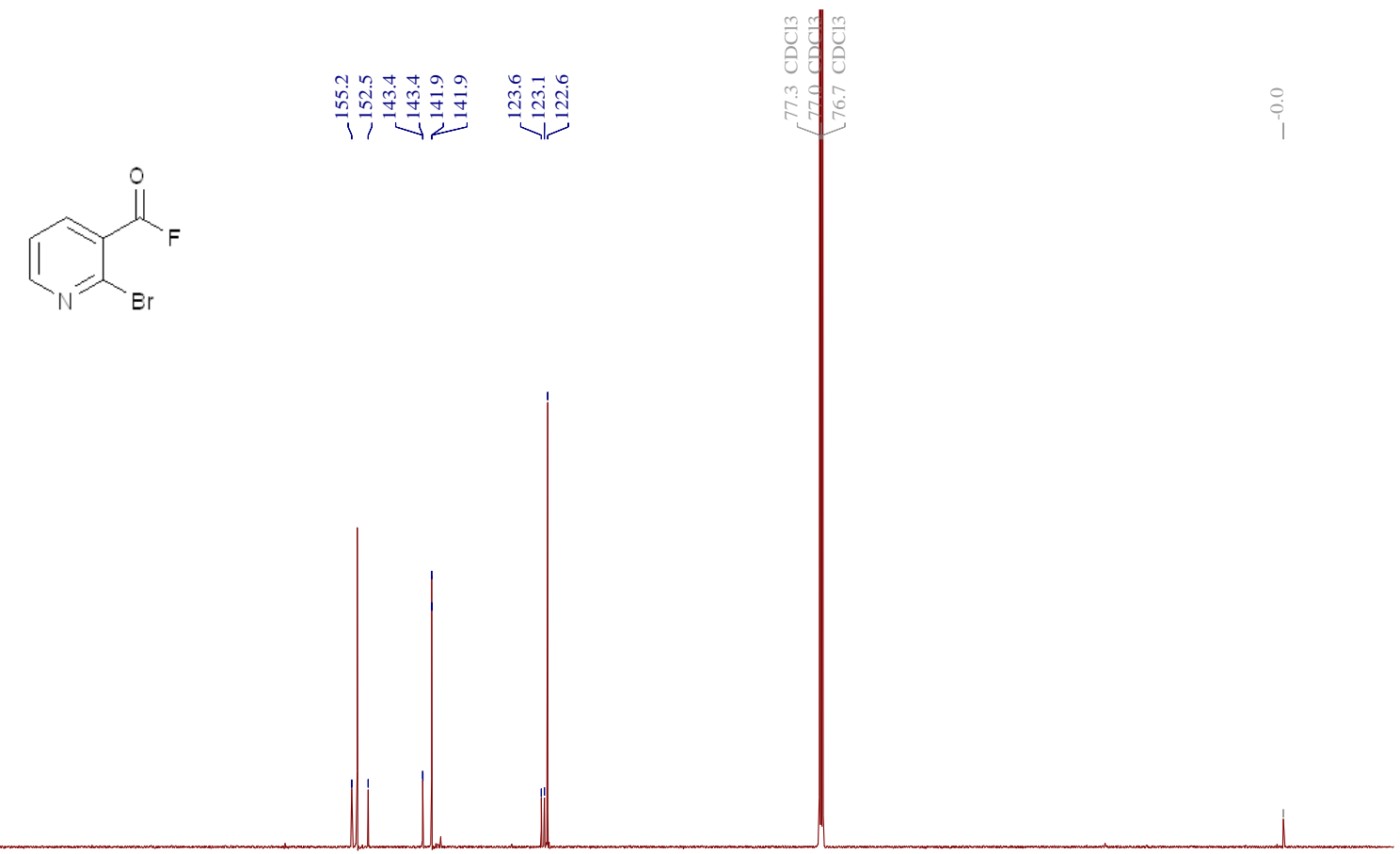

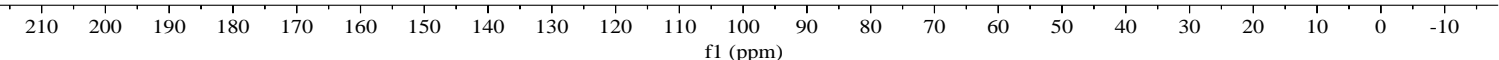

${ }^{19}$ F NMR (282 MHz, $\mathrm{CDCl}_{3}$ )

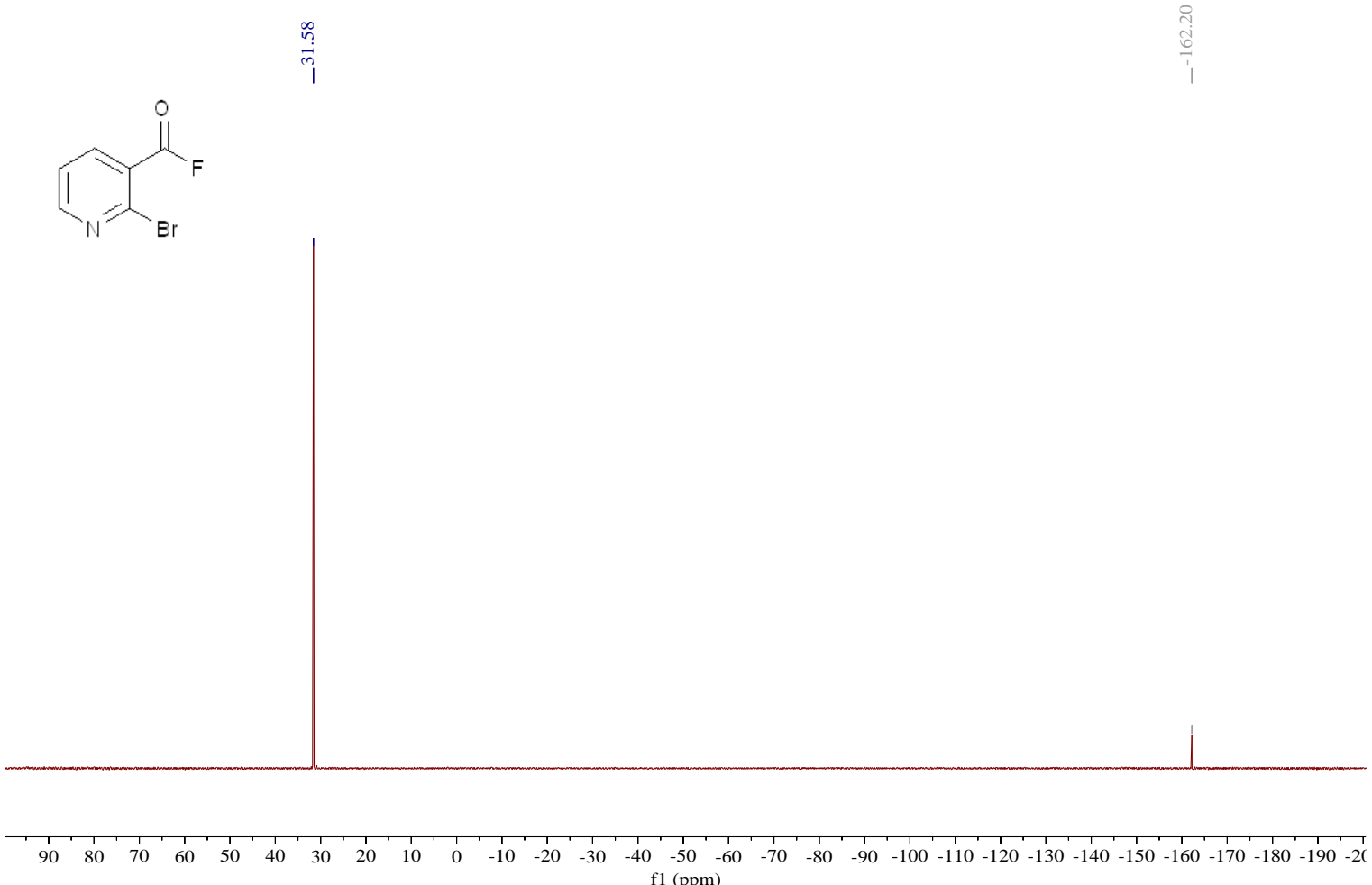


$N$-Benzylcyclopropanecarboxamide (5zi).

${ }^{1} \mathrm{H}$ NMR (300 MHz, $\mathrm{CDCl}_{3}$ )
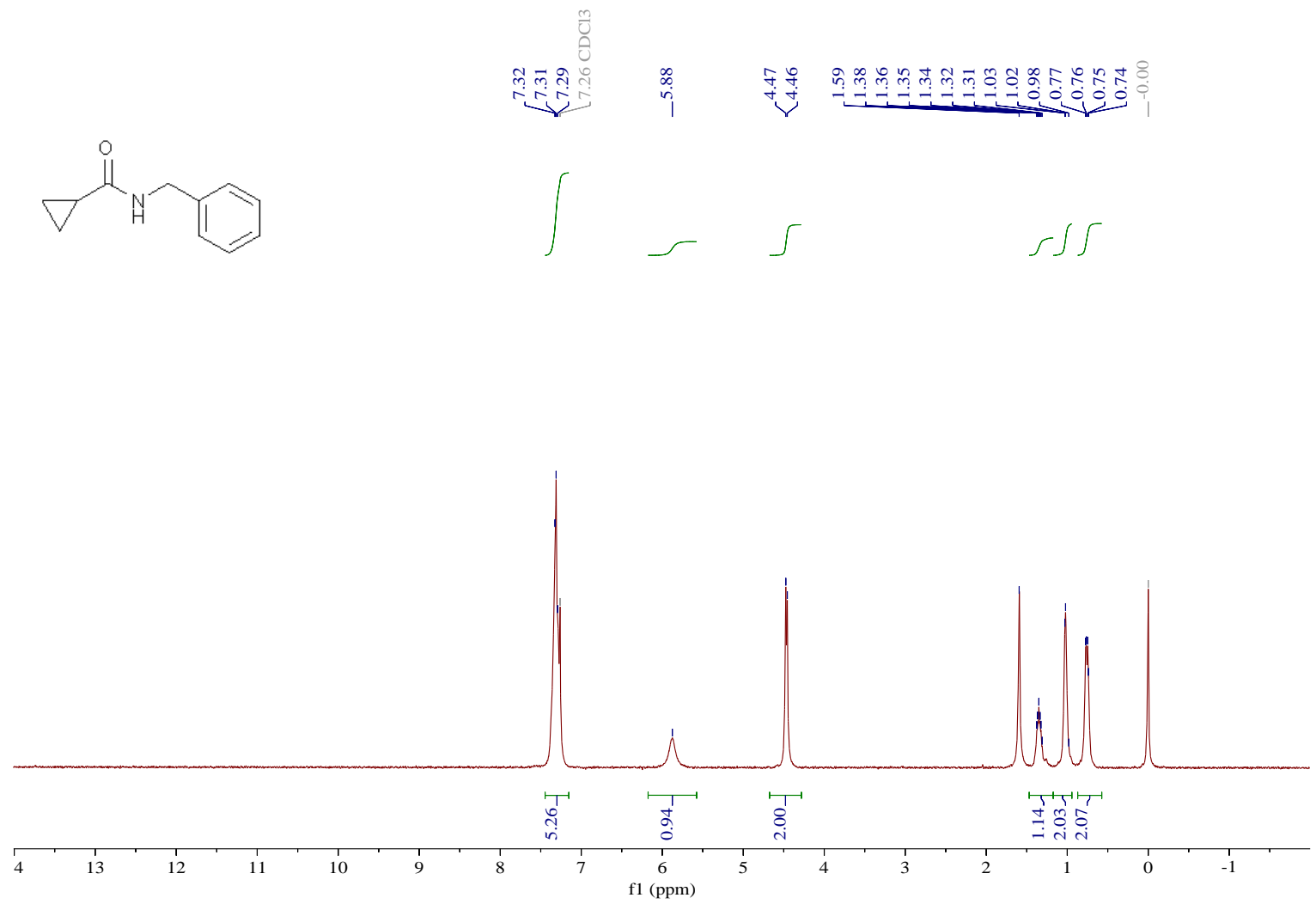

5,5-Diphenyl-4,5-dihydroisoxazole-3-carbonyl fluoride (1zj).

${ }^{1} \mathrm{H}$ NMR (300 MHz, $\mathrm{CDCl}_{3}$ )

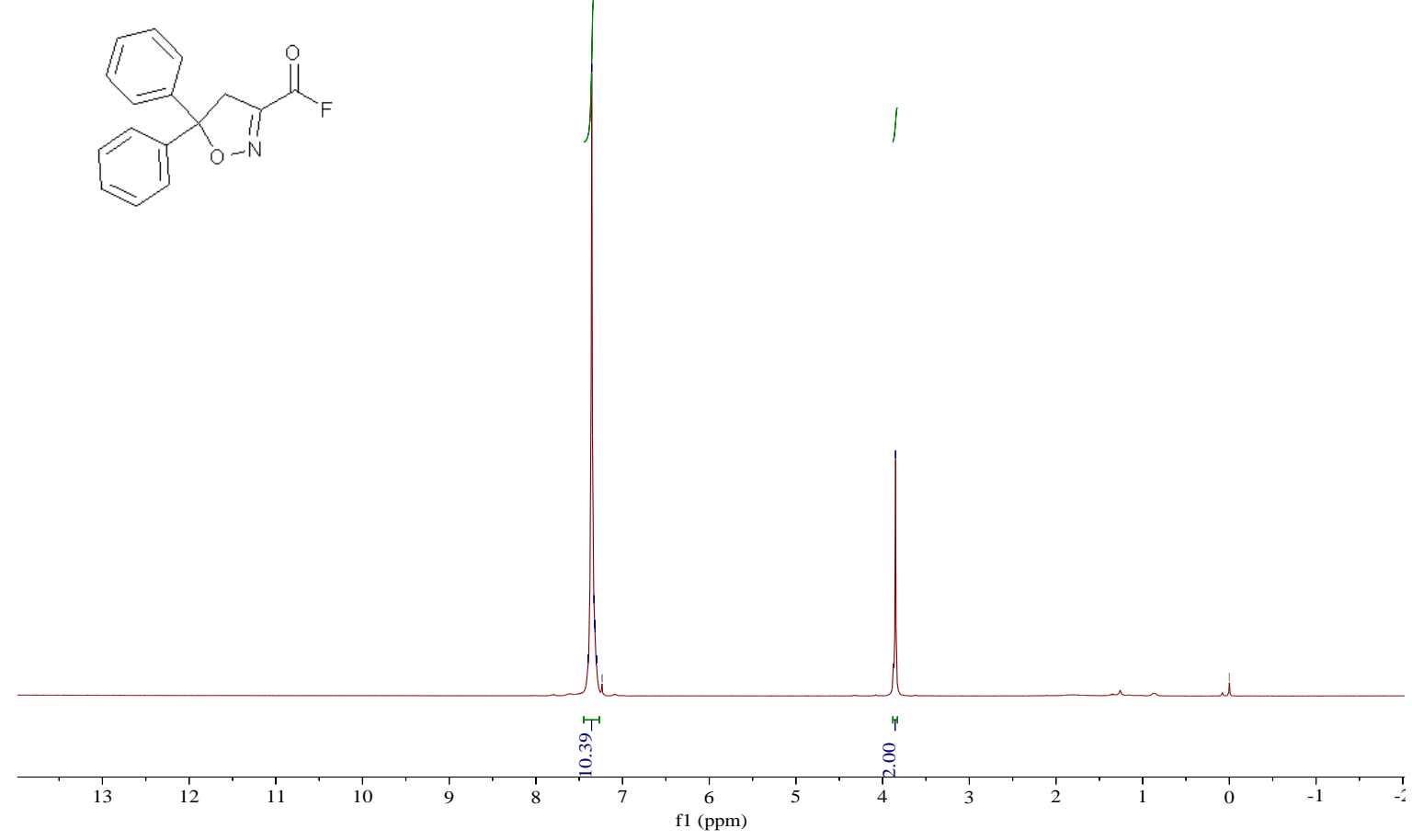


${ }^{19}$ F NMR (282 MHz, $\left.\mathrm{CDCl}_{3}\right)$

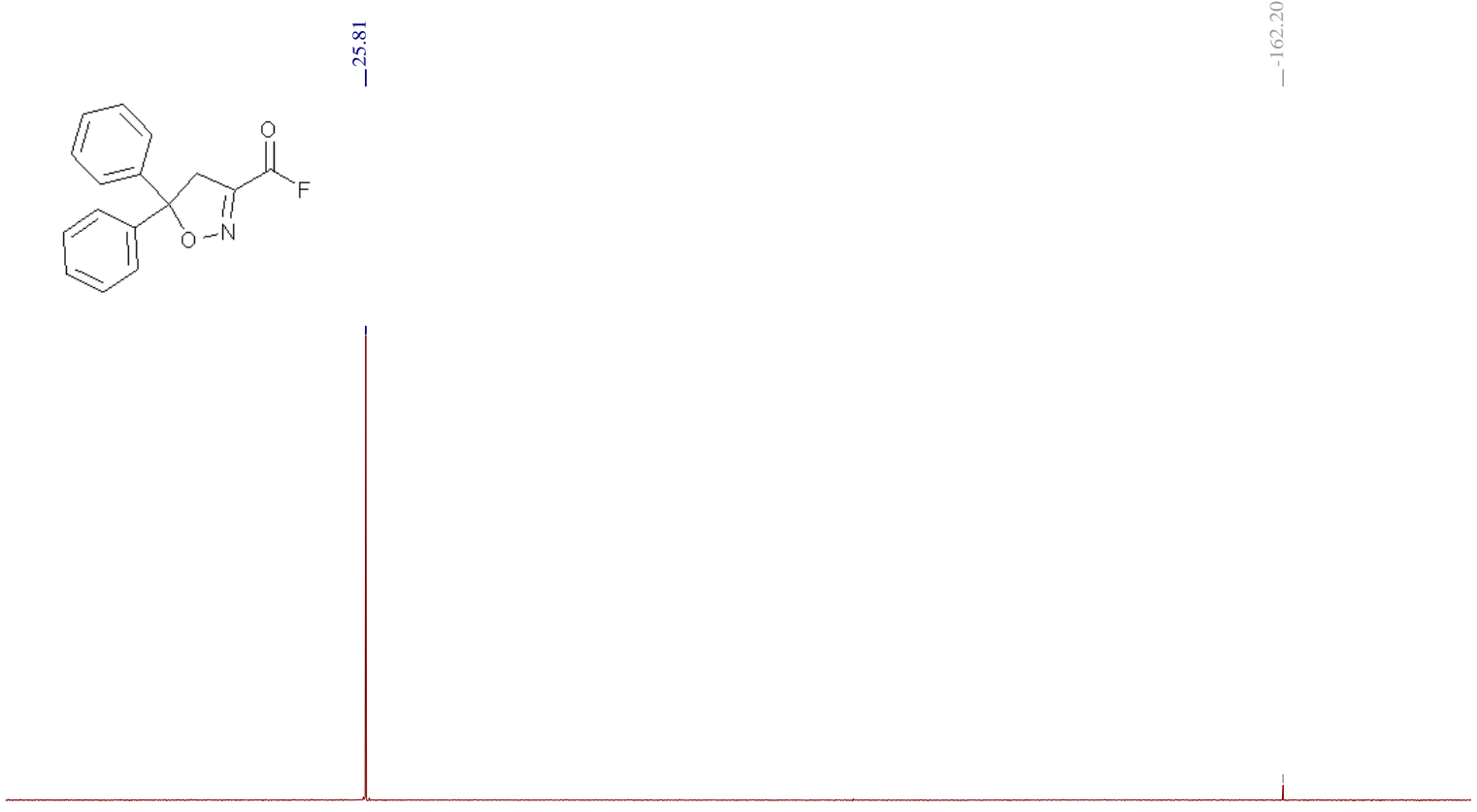

$\begin{array}{lllllllllllllllllllllllllllllllllllll}90 & 80 & 70 & 60 & 50 & 40 & 30 & 20 & 10 & 0 & -10 & -20 & -30 & -40 & -5 & -60 & -70 & -80 & -90 & -100 & -110 & -120 & -130 & -140 & -150 & -160 & -170 & -180 & -190 & -2(\end{array}$

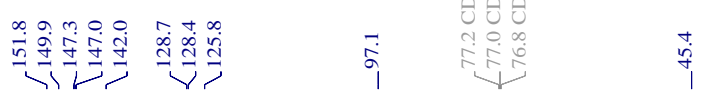<smiles>O=C(F)C1=NOC(c2ccccc2)(c2ccccc2)C1</smiles>

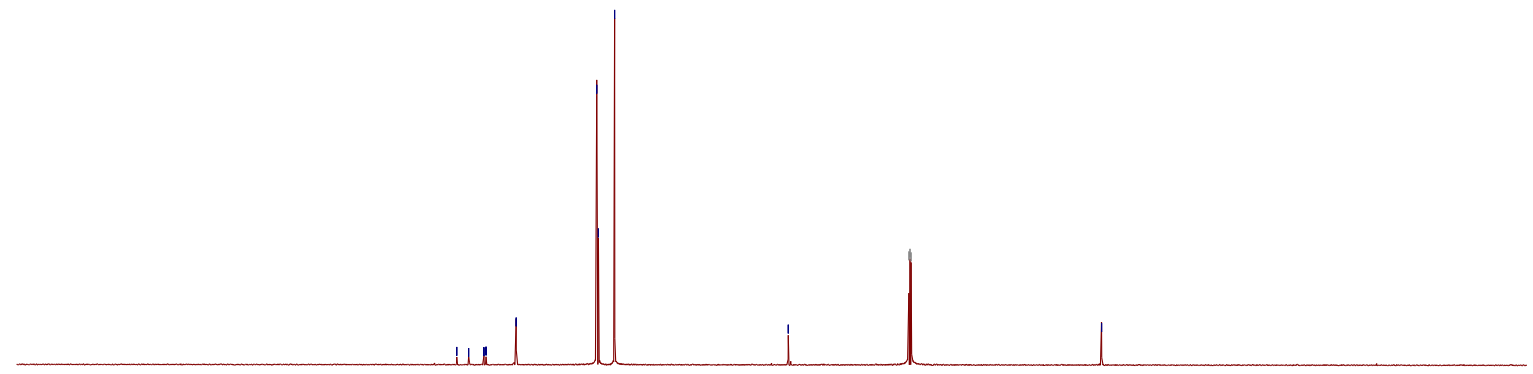

$\begin{array}{lllllllllllllllllllllllllll}220 & 210 & 200 & 190 & 180 & 170 & 160 & 150 & 140 & 130 & 120 & 110 & 100 & 90 & 80 & 70 & 60 & 50 & 40 & 30 & 20 & 10 & 0 & -10 & -20\end{array}$ 